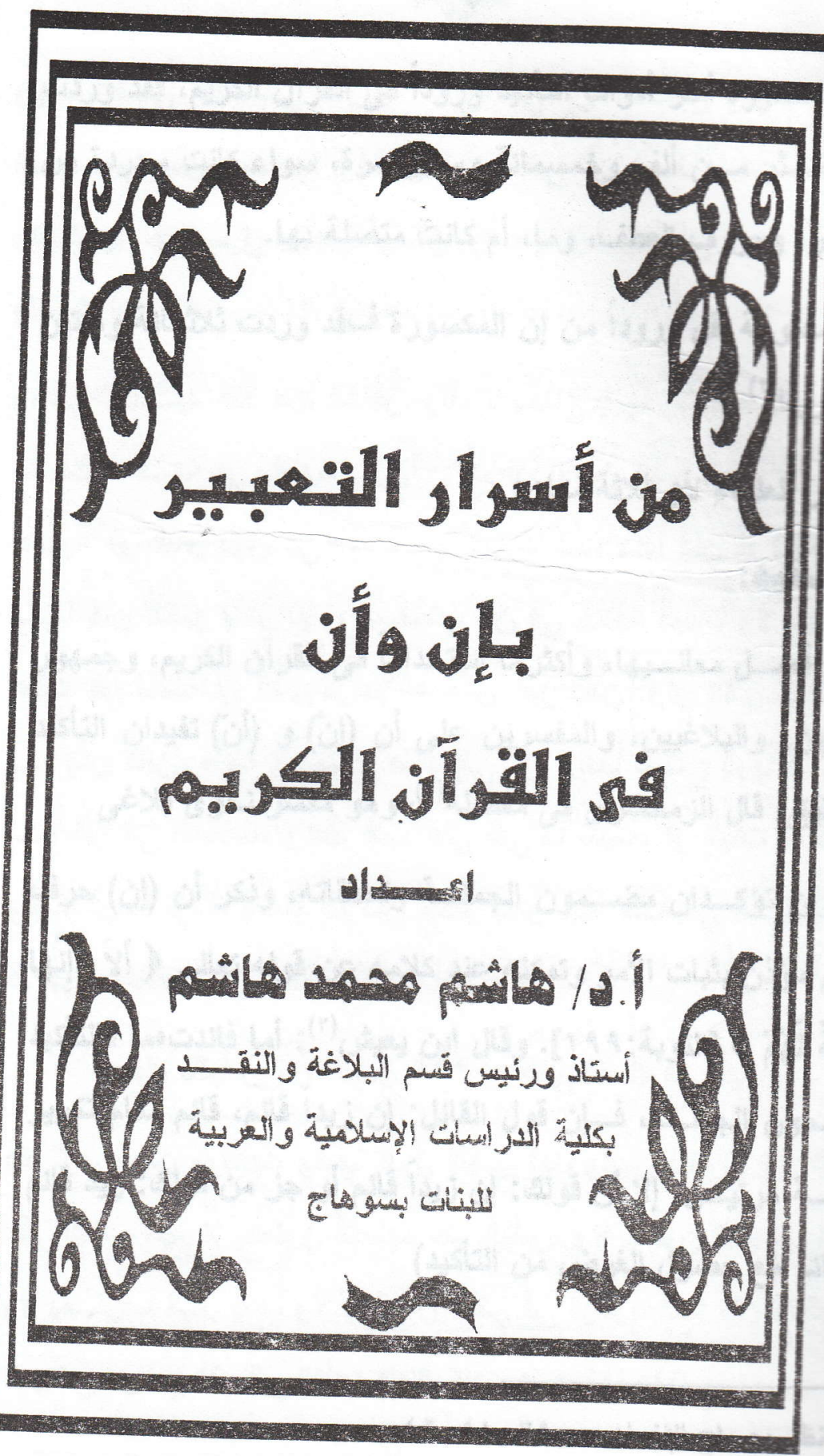




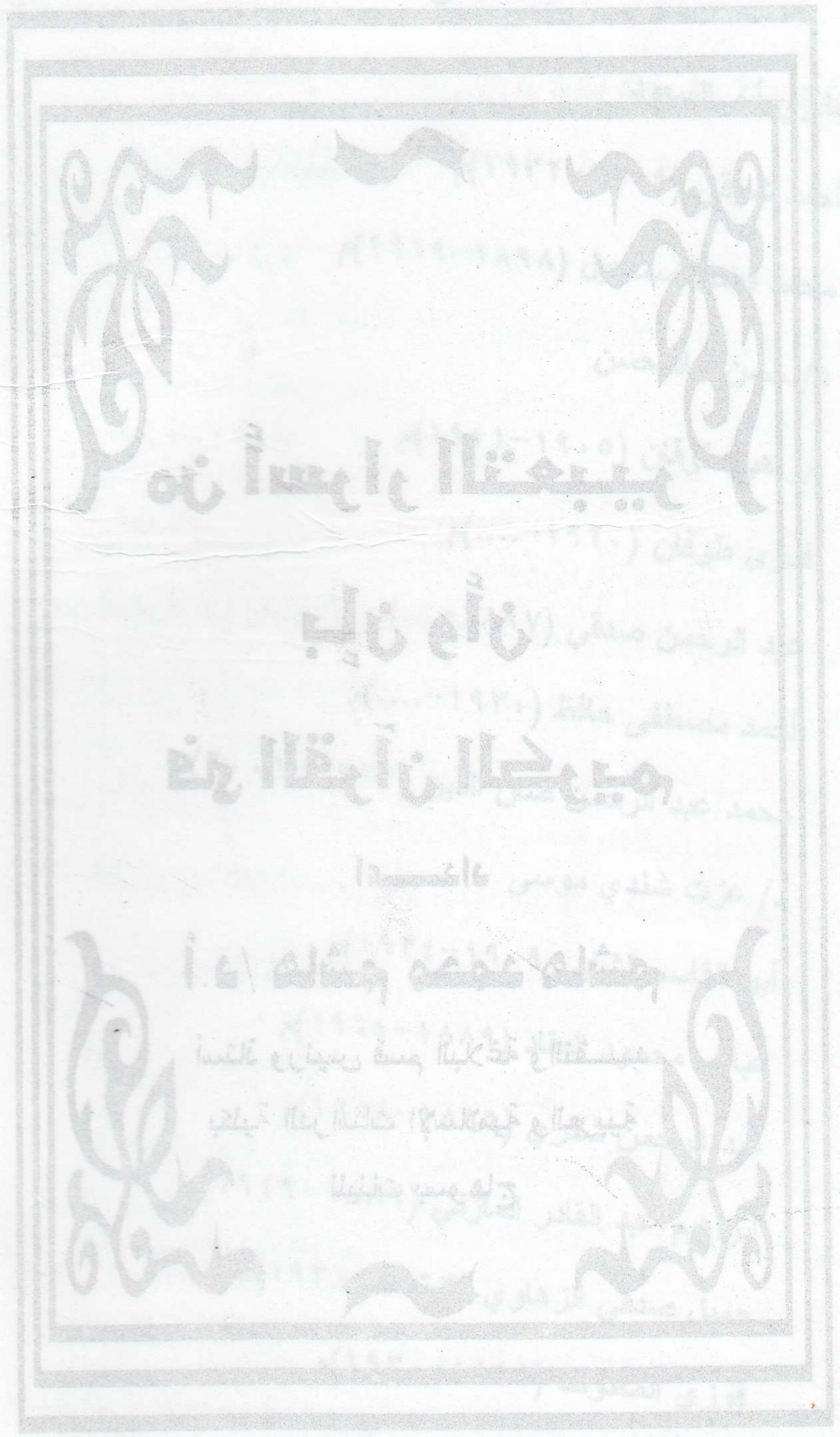




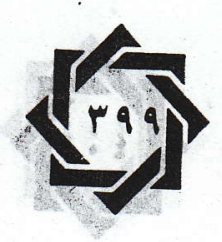

إن المكسيـورة أكثر أدوات التأكيد ورودأ في القرآن الكزيم، فقد وردت

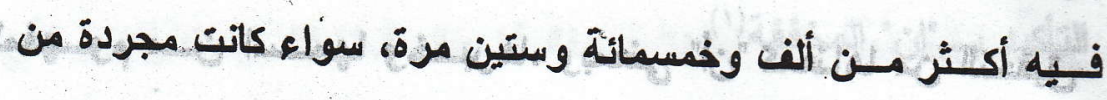
الضيائر، وحروف العطف، وما، أم كانت متصلة بها. وأن المفتوحة أقل وروداً من إن المكسورة فند وردت ثلأمائة وستين مرة تقريبا(1) وقد ذكر العلماء لأن تُلاحة معان:

\section{أولا التأكيد:}

وهــو أصـل معانــــها، وأكثرها استخدامأ فى القرآن الكريم، وجمهور النحويين، والبلاغيين، والمفسرين على أن (إن) و (أن) تفيدان التأكيد

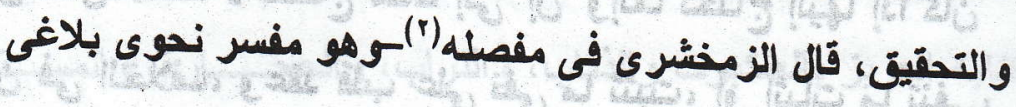

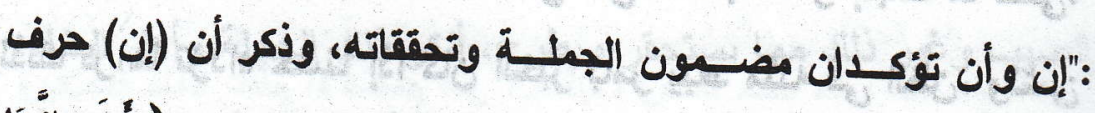
تحقيق مؤذن بثبات الأمر وتمكنه عند كلامه عن قوله تعالى (ألاَ إنَّهَا

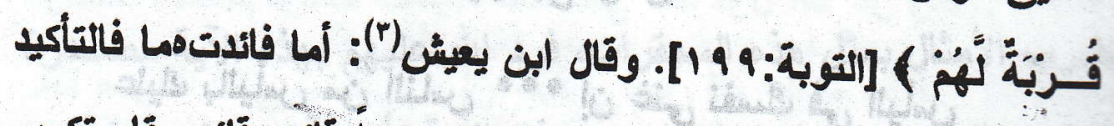
لمضـــون الجملــة، فــإن قول القائل: إن زيداً قائم، قائم مقام تكرير

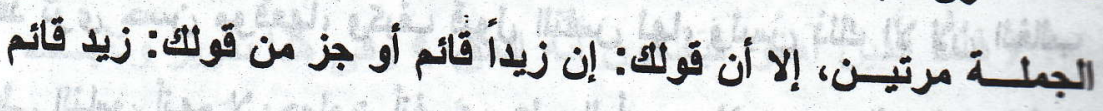
زيد قائم مع مصول الغرض من التأكيا)

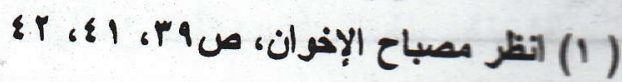

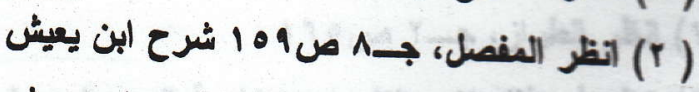

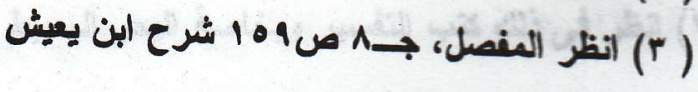




\section{匍}

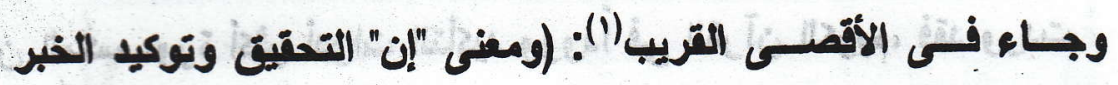

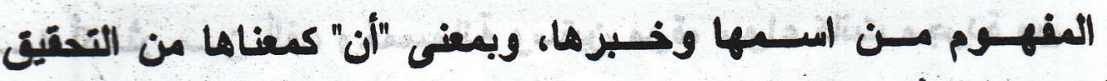

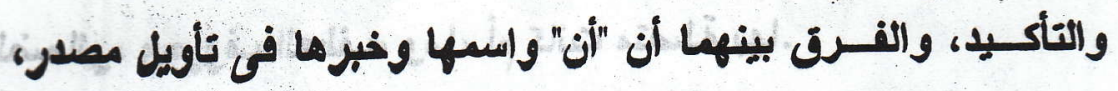
وليست إن كذلتص"

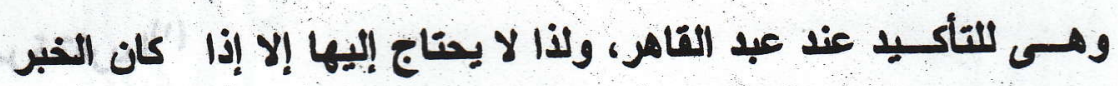

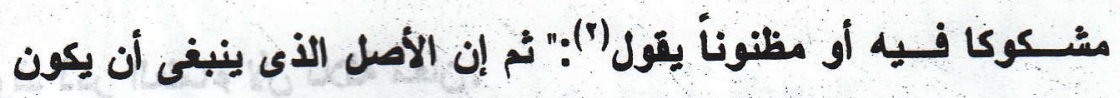
عابها هو الذى دون فى الكتب من أنها للتأكيد، وإذا كان قد ثبت ذلك،

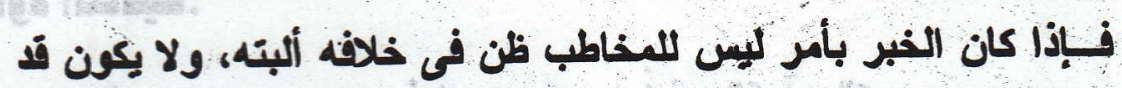
عتــ فى نفسه أن الأى تزعم أنه كائن غير كائن، وأن الذى تزعم أنه

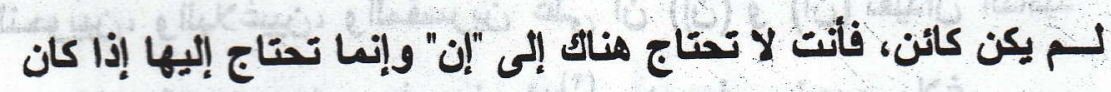

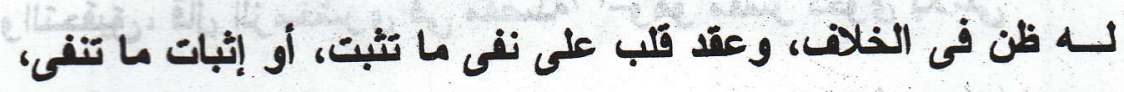
ولذلك تراها تزداد حسنا إذا كان الخبر بأمر يبعا مثله فى الظنه، ولشئ قد جرت عادة الناس بخلافه كقول أبى نواس. عليك بالياس من الناس " * "إن غنى نفسك فى اليأس

فتل ترى حسن موقعها، وكيف قبول النفس لها، وليس ذلت إلا لأن الغالب

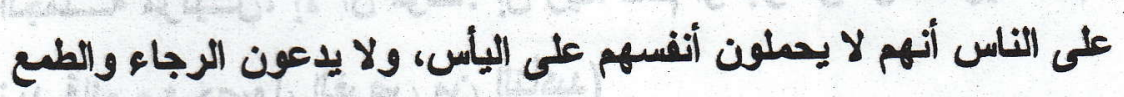
ولا يعـترف كـلـ أحد، ولا يسلم أن الغنى فى الياس، فلما كان كذلك كان العوضع موضع فتر إلى التاكيد فلألك كان من حسنها ما ترى.

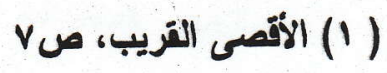

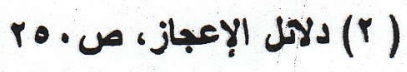




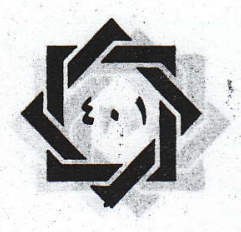

ونص على ذلت العوى، وذكز أن التأكيد بـ "إن" المشددة آكــــــن مـن

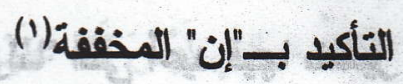

وخلاصة القول أن "إن" فائدتها تأكيد النسبة وتمقيقها، ولذك بتلى بها

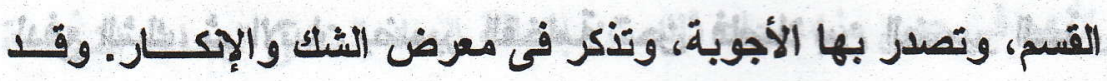

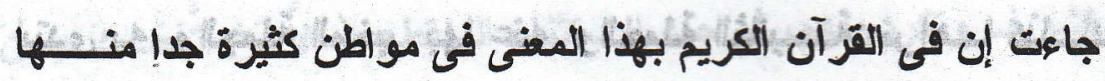

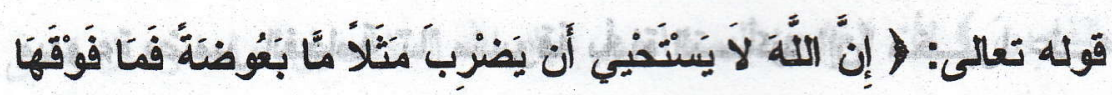

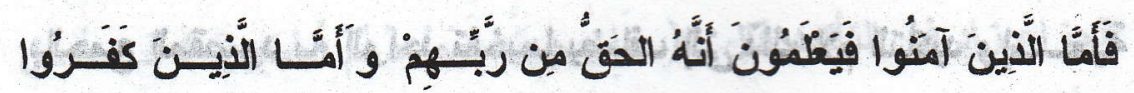

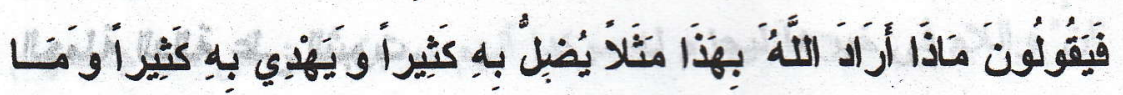

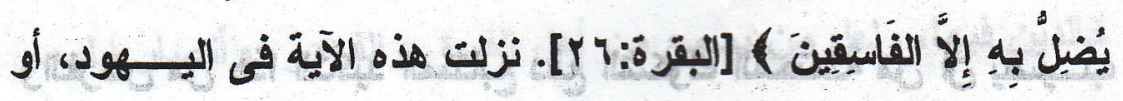

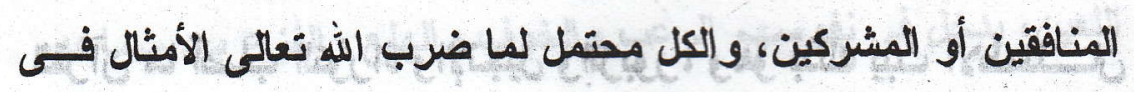

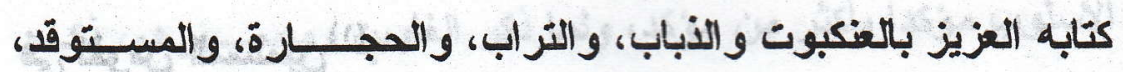
والصيب وغير ذلك مما يستحقز ويطرح، أنكر ذلك الجهلة وأهل العناد،

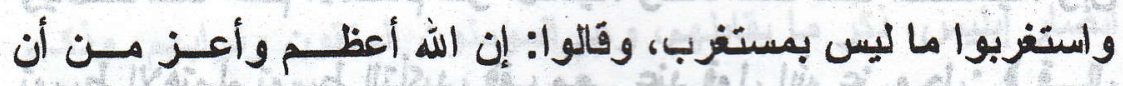
يضرب الأمثال بمثل هذه المحقرات، فرد اله عليهم بهذه الآية مصـدرة

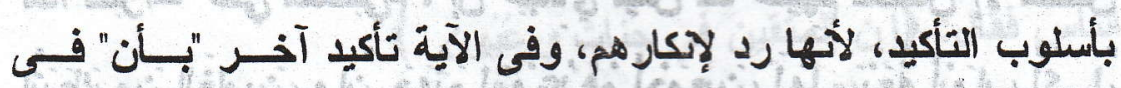

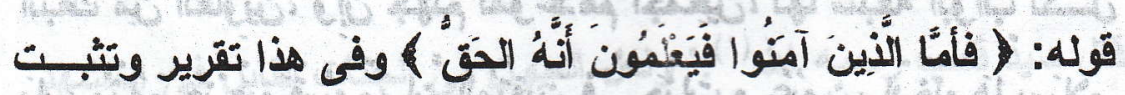

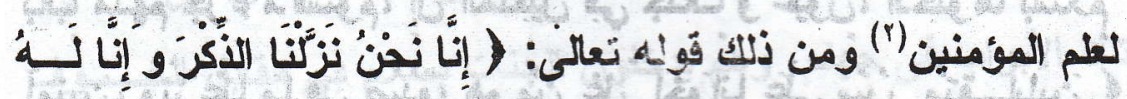
لَحافظظون ) [العبر:9] فأمام شدة إنكار المشركين إنزال القرآن مـــن

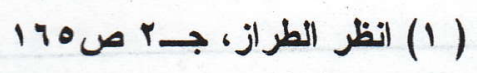

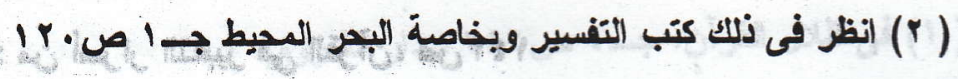




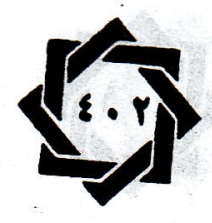

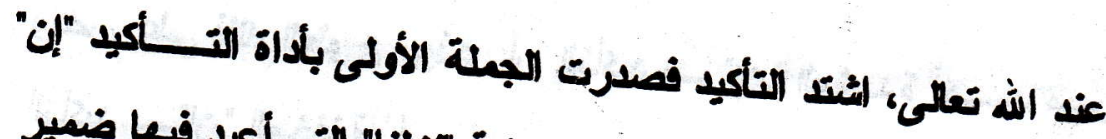

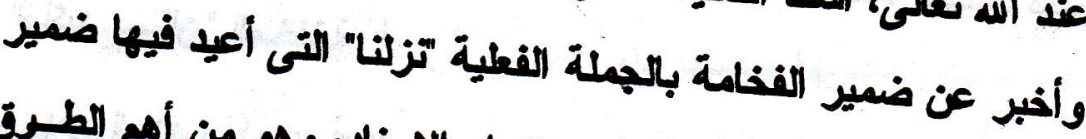

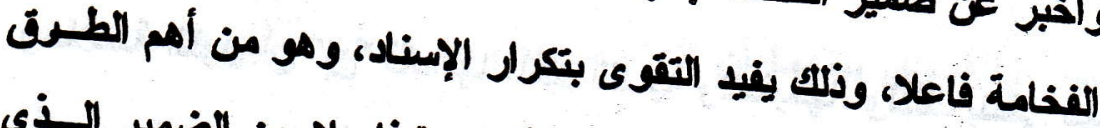

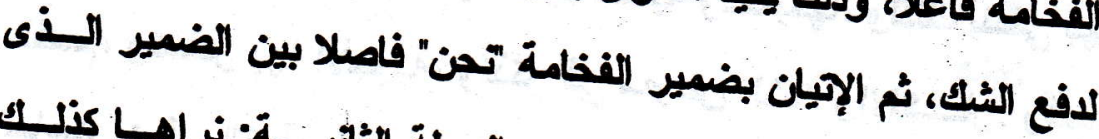

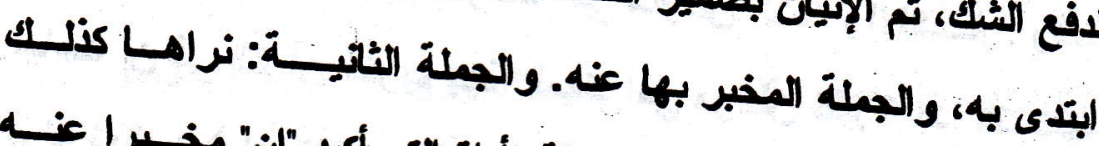

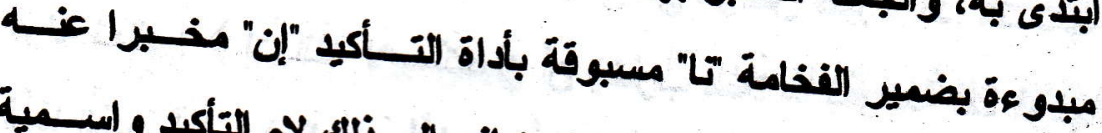

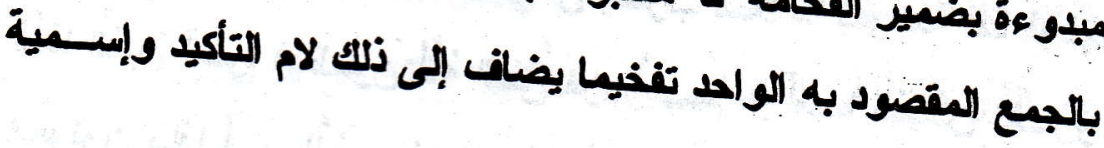
الجبلة الدالة على الثبوت.

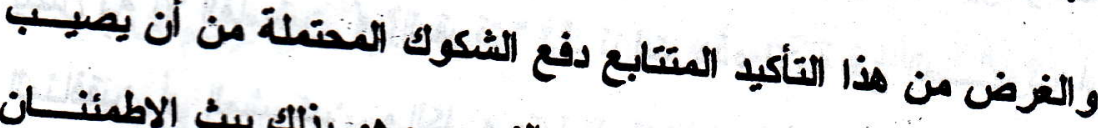
القرآن ما أصاب التوراة والإجيل وإلزيور، وهو بذلك يبث الاطهئــان

في نفوس المسلمين (1).

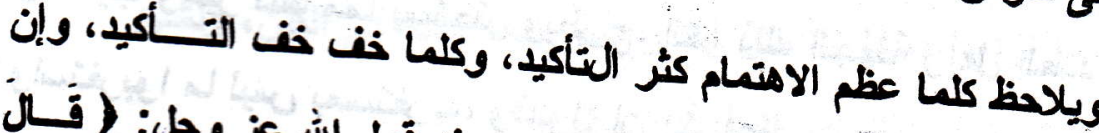

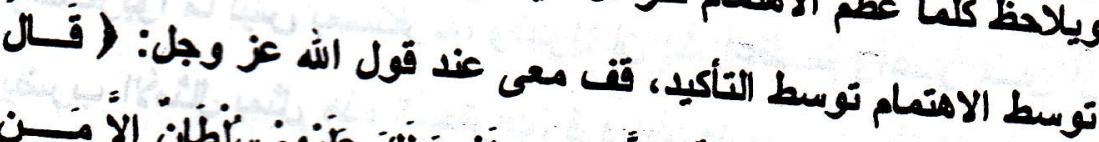

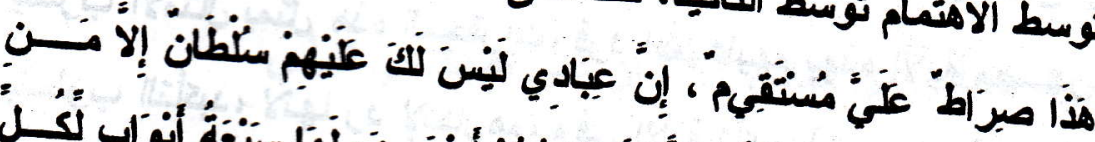

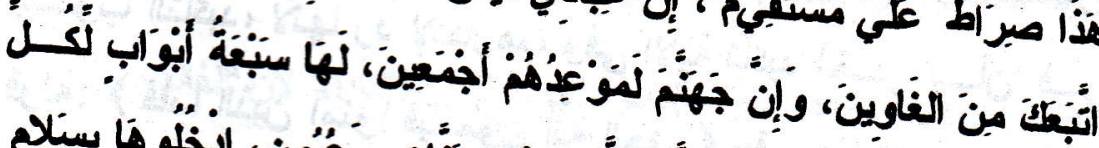

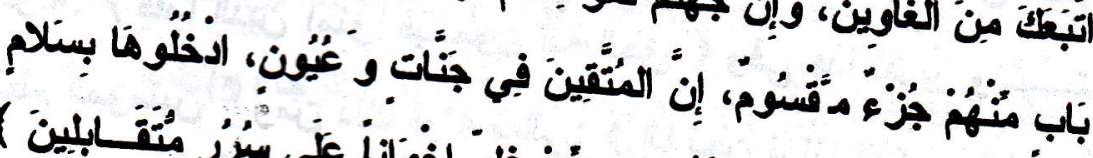

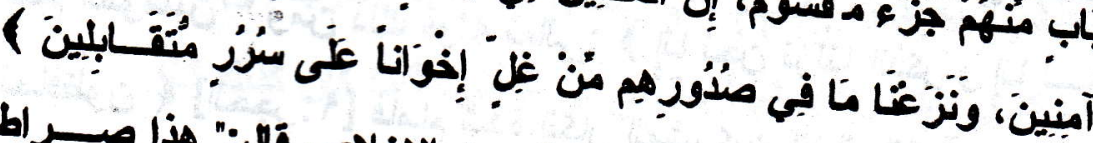

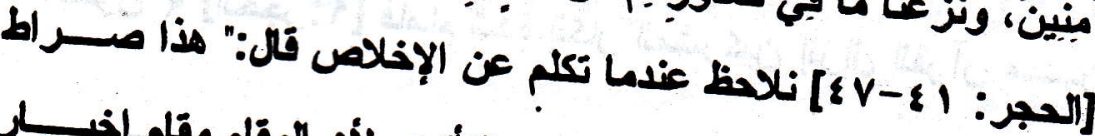
على مستميم " جاء الأسلوب خاليا من التأكيد، لأن العتام مقام إخبــار

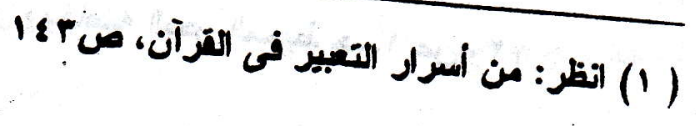




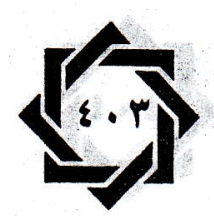

مطلق لا يحتاج إلى تأكيد، وعندما وجه الكلام إلى إيليس اللعين قـال:

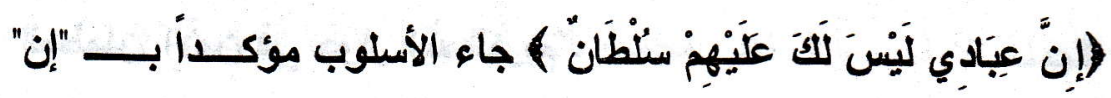

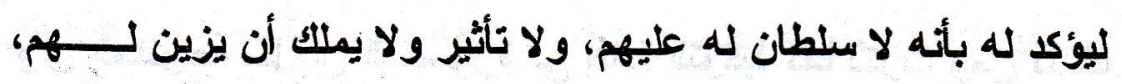

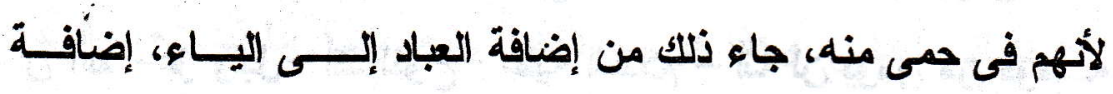

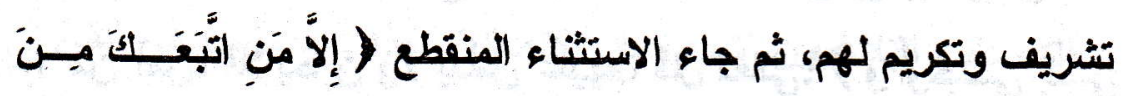

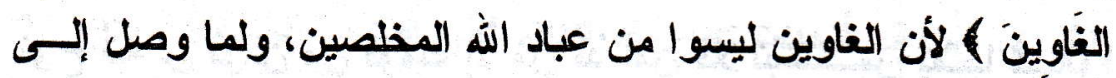

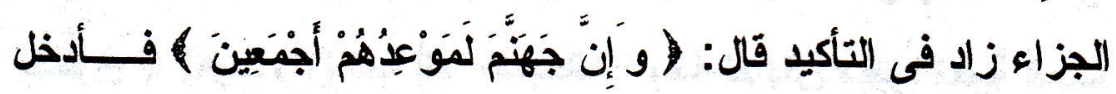

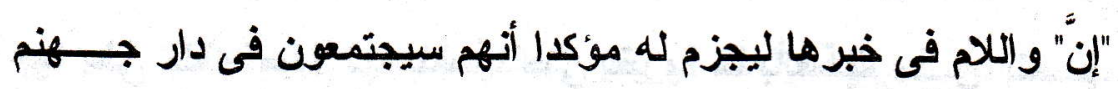

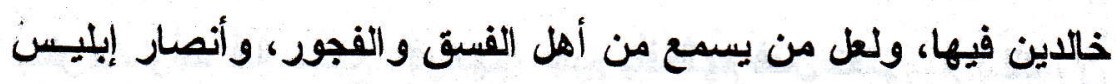
اللعين، يلخل فى نفوسهم الرعب والخوف و الهائع والفزع بع سماعهم

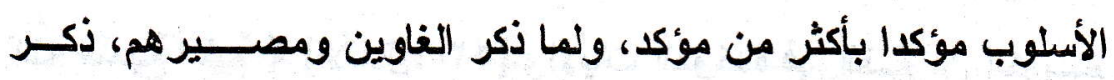

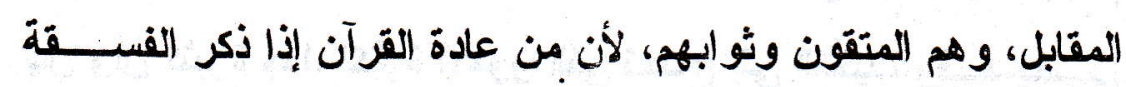
أنصار إبليس، ذكر ما يقابلهم، وهم المؤمنون المتقون وثوابهم، وذنكو

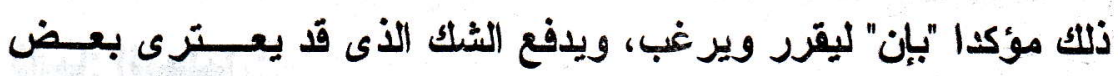

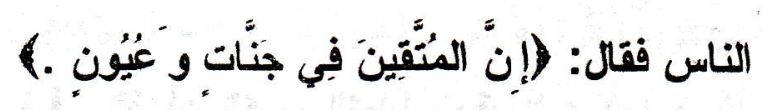

قال سيد قطب رحمه اله"'):" ولعل العيون فى الجنات تقابل فى المشهر

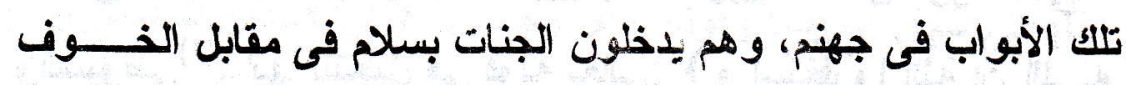

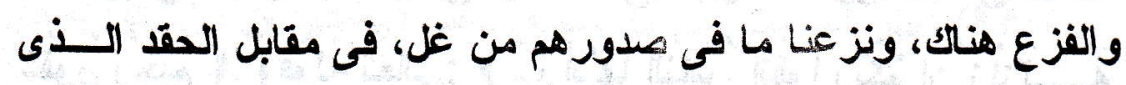

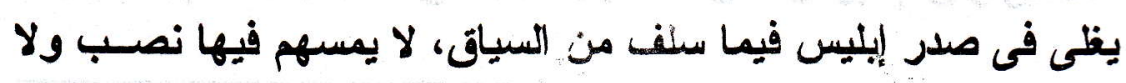




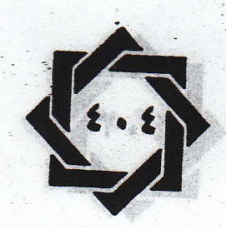

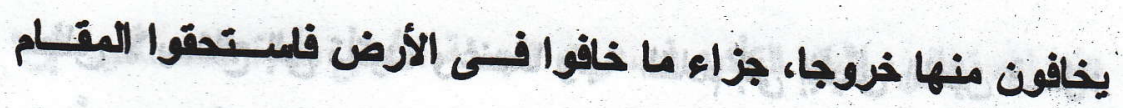
المطمئن الآمن فى جوار اله الكريم".

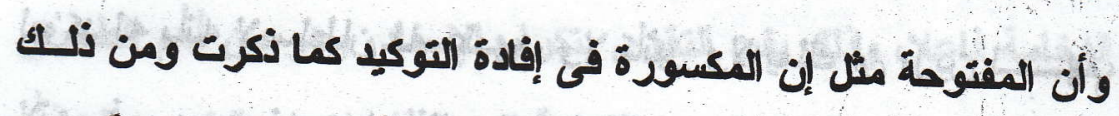

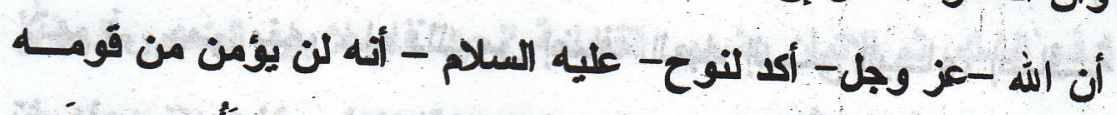

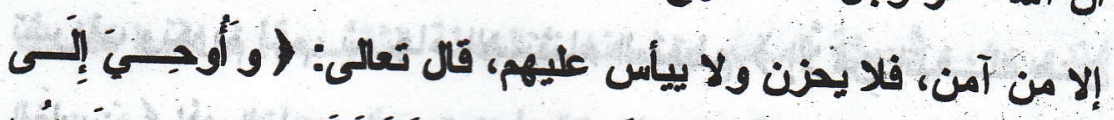

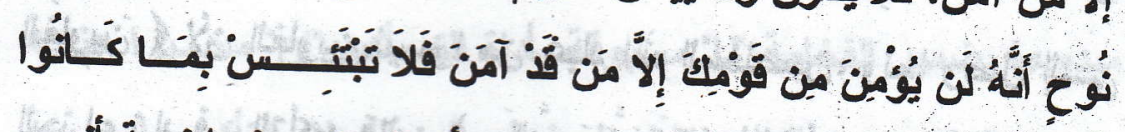

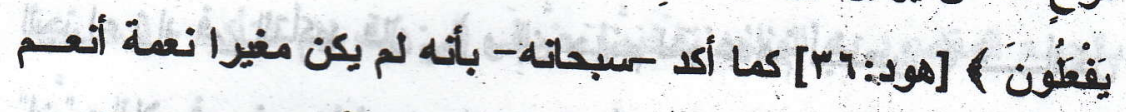

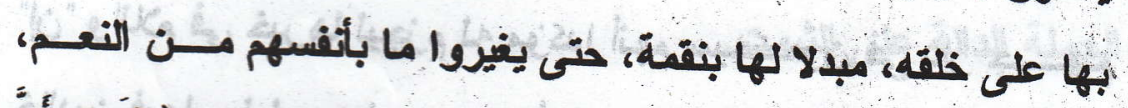

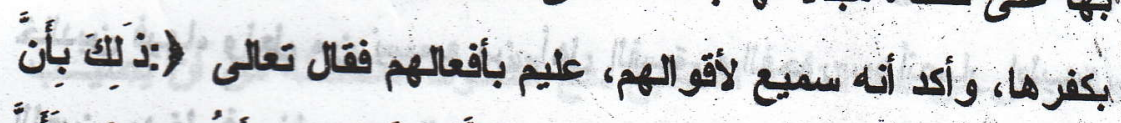

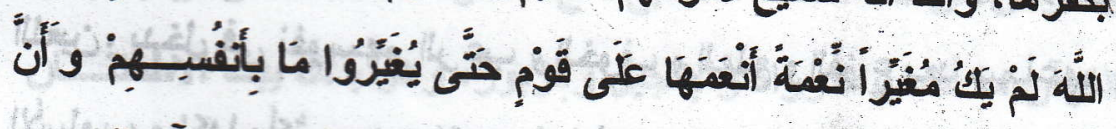

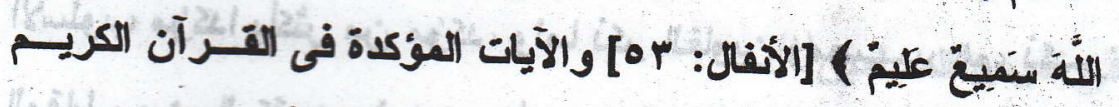

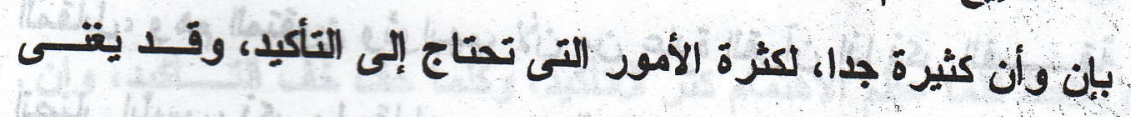
ذكر البعض فى هذا الموطن عن الكل.

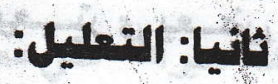

من معاتى "إن" العكسورة فى القرآن الكريم التعليل، وقد أثبت لها هــا

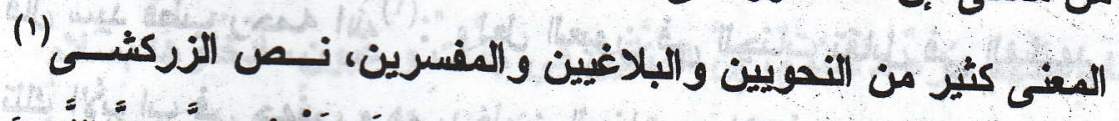

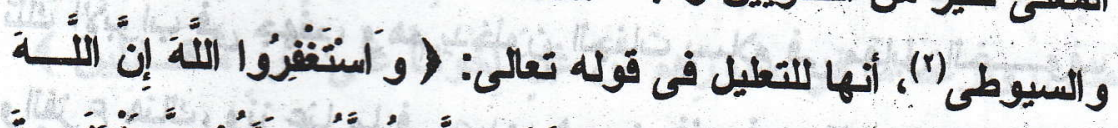

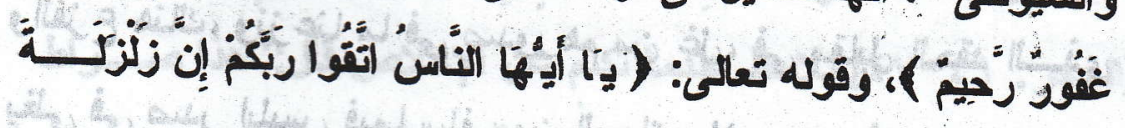

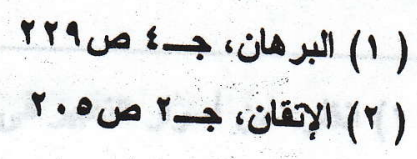




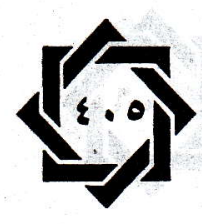

الستَّاعِة شَيْهُ عَظِيمُ ) [الحج: 1] وكثير من الآيات التــى يفـهم مـن الجملة الأولى سؤال تأتى الجملة الثانية جوابا عنه، أو كـالتعليل لــه، ويؤكد التعليل لتقوية مضمون الخبر وربطه بمـــا قباـــه عــن طريــن الاستئناف البيانى، وهذا هو سر الفصل بينه، وبين ما قبإسـه، والـــى يطلق عليه البلاغيون "شبه كمال الاتصال" وهذا باب متسع فى القــــآن الكريم، وسوف أتحث عنه عند الكلام على أضرب الخبر.

وأما "أن" المفتوحة، فلم يثبت لها أحـ هذا المعنى، بل قــالوا: جـــاءت بمعى لعل فى آية واحدة فى القرَآن الكريم وهى قوله تعالى: (وَمَتسـا

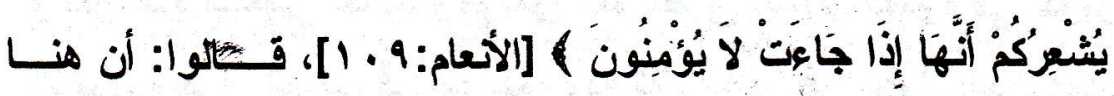

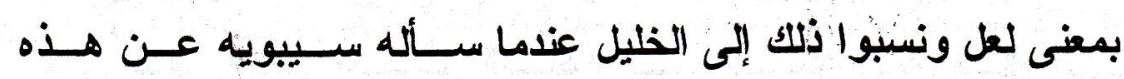
الآيةل(1)، وقال الزمخشرى (†): وقيل: أنها بمعنى لعها. من قول العرب: إئت السوق أنكت تشترى لحما، وقال امرؤ القيس: عوجا على الطلل المحيل لأنا *** نبكى الايار كما بكى ابن خذام وتقويها قراعة أبى " لعلها إذا جاعت لا يومنون ".

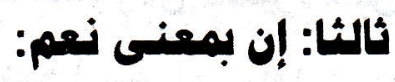

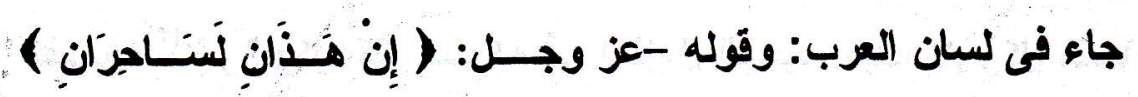

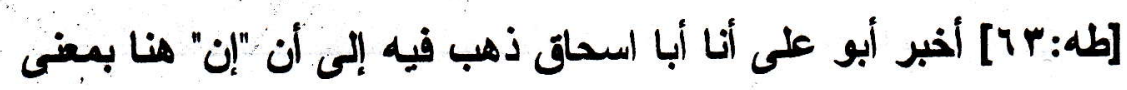




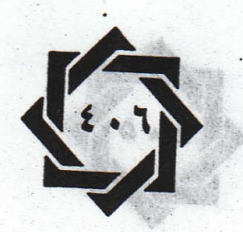

نعم، وهذان مرفوع بالابتداع، وأن البلام فى "لساحران" داخلة على غير ضرورة، وأن تقديرهم: نعم هذان ساحران. ونسبوا ذلات إلى سيبويد، والأخفش، والمبرد. وبعض النحويين قالواء: إنها بمغنى "ما" و الكلام بمغى "إلا"(1) و البلاغيون لم يتعرضوا لهذا المفى ولم بذكروه -على ح على -وإن فى الآية تفيد التأكيد، ويفه منها معنى الايجاب عند التشديد. وأرى أن الحق معهم ولا داعى للخلافات الكثيرة.

وأكثر هذه المعانى التأكيا وهو من أهم الطرق التشيت الفكرة فى نفوس

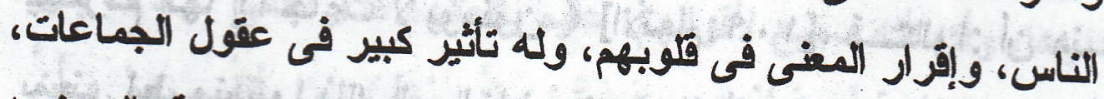

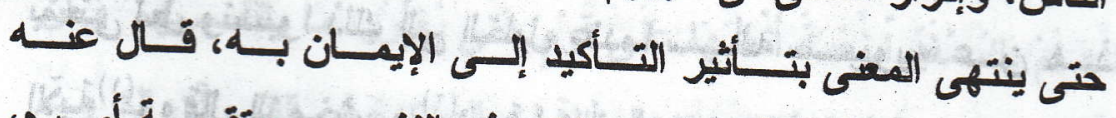

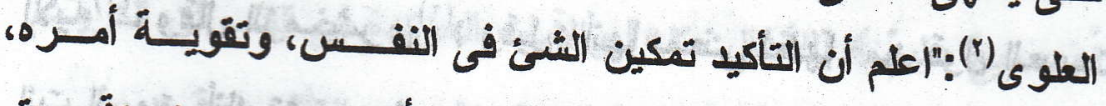

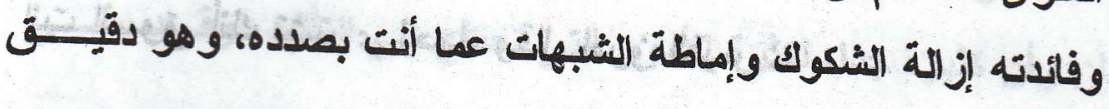
المأخذ كئر الفوائد". ولقد كثر هذا الأسلوب فى القرآن الكريم حتى أجمع جمهر الأمة على

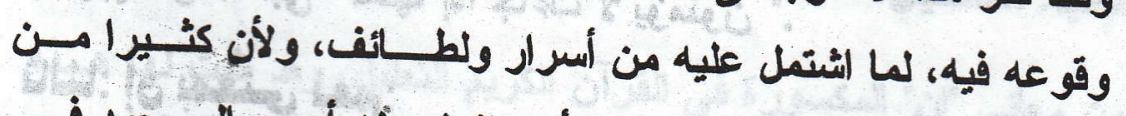

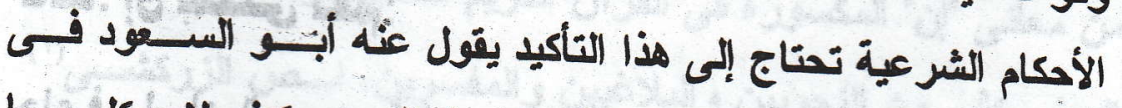

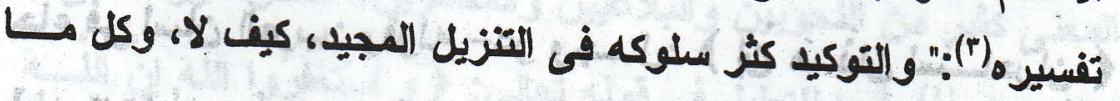

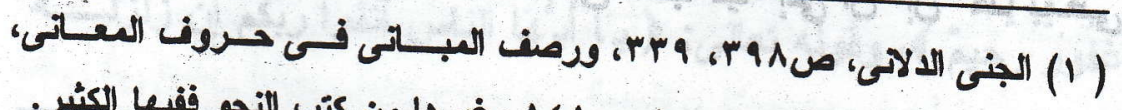

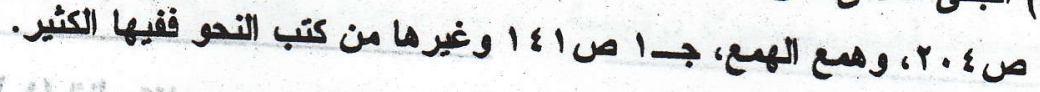

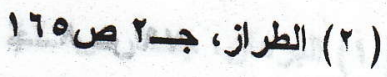

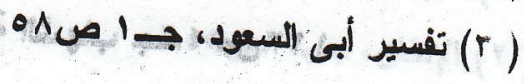




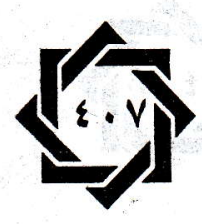

ورد فى تضاعيفه على العباد من الأحكام و الثر ائع وغير ذلك خطــوب جليلة حقيقة بأن تقشعر منها الجلود، فاقتضى الحال المبالغة و التأكيد. ومما دعا إلى وجوده فى القرآن الكريم أن كثيرا من الناس يكرهـــــــ

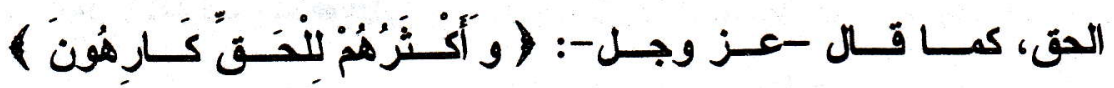

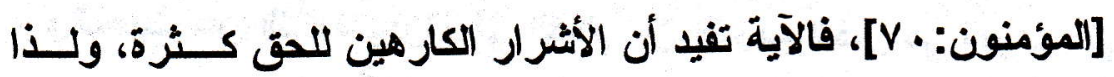

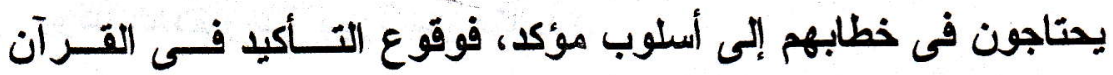

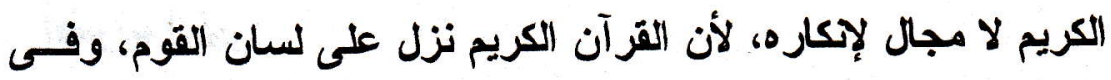

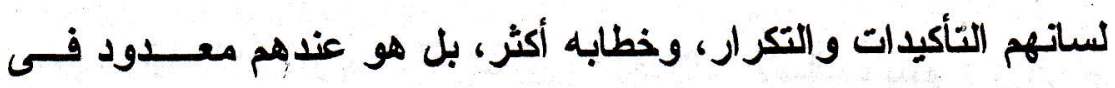

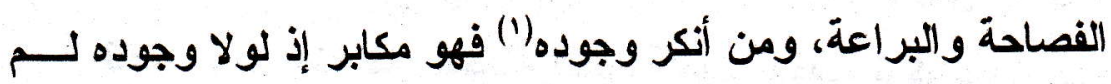
يكن لتسميته تأكيدا فائدة، فإن الاسم لا يوضع إلا لمسمى معلوم"(r) عناصر التأكيد وأدواته: عناصر التأكيد كثيرة، وأدواته متعددة قال عنها الدكتور محمــــــ أبـو

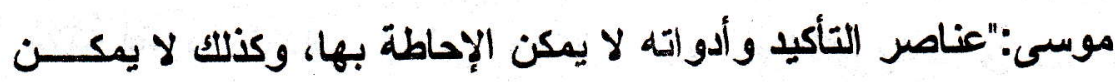
إحصاؤها، لأن كثيرا من طرق بناء الكلام تعطيه قوة ووكادة(r) أههـا:إن، وأن، وقد، و القسم، ولام الابتداء، وأحرف التتبيــهـه وهـى: ( 1) أنكر بعض العلم ، وجود النذكيدات فى القرآن والسنة، وقالوا: إنه لا فــائدة

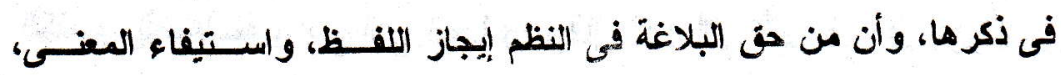

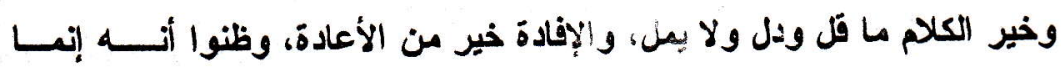
يجئ لقصور النفس عن تأدية العراد بغير تأكيد.

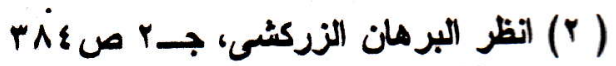

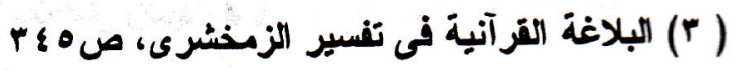




\section{$\sqrt{n-1}$}

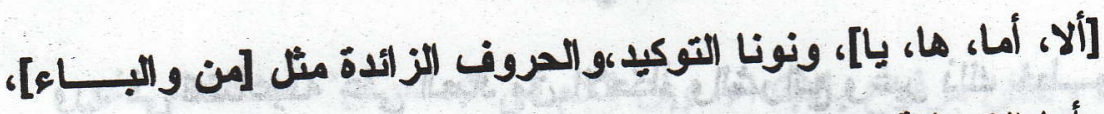

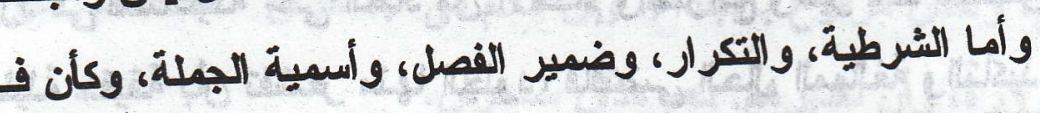

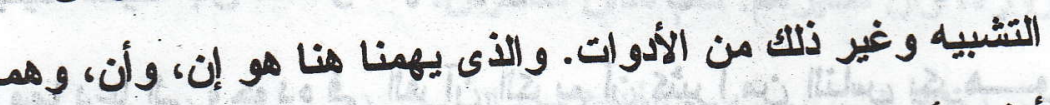
أكثر الأدوات استعمالا.

والحديث عن التأكيد يجرنا إلى الكلام عن أضرب الغبر كى نعرف منى يوكد الكلام ومنى بيرد من التأكيد؟. أضرب الهن:

من مزايا اللغة العربية دقة التعبير، واختلاف الاسايبب يتنوع الأغر اض

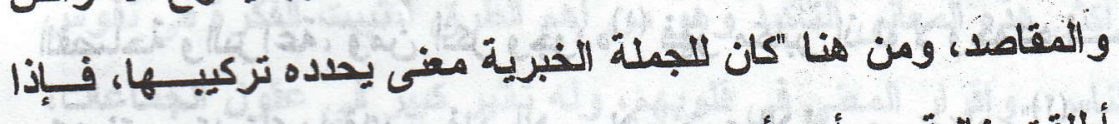

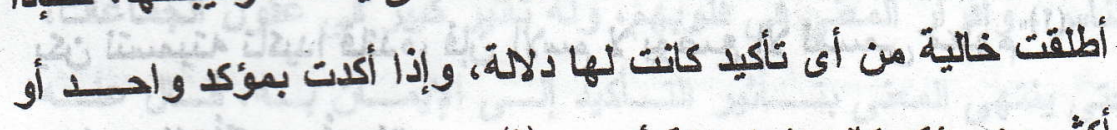
أكثر من مؤكد كانت لها دلالة أغرى. (1)

وقد تنبه البلاغيون إلى هذا فقسموا التبر حسب حالات الفخاطب إلـى

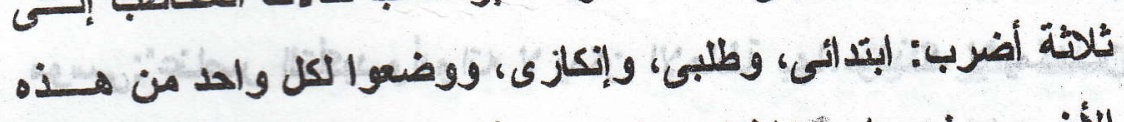

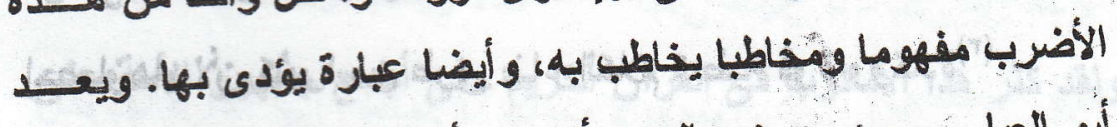

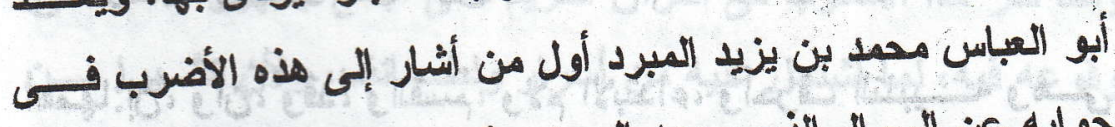

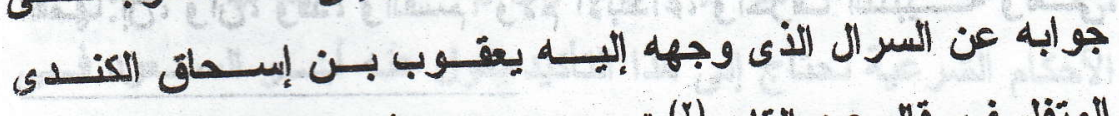

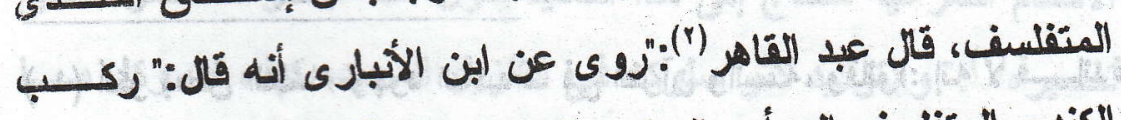

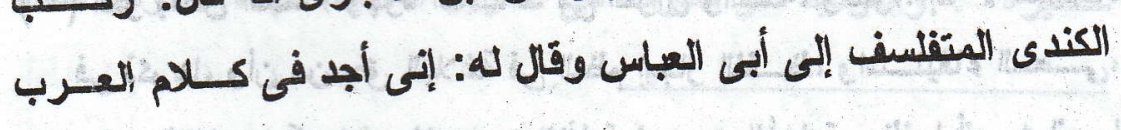




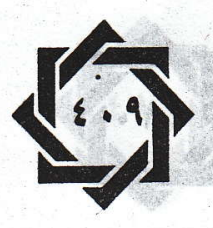

حشوا، فقال له أبو العباس: فى أى موضع وجدت ذلك ؟ فتــال: أجـــ

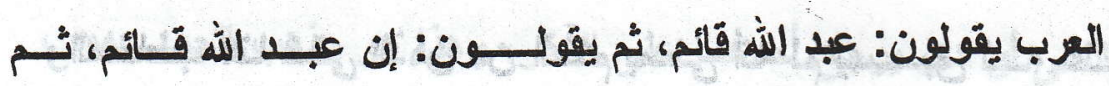

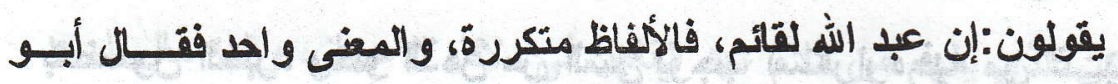

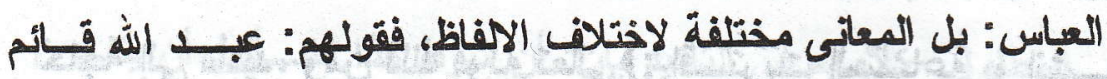
إخبار عن قيامه، وقولهم: إن عبد الله قائم: جواب عن سؤال ســـــائل،

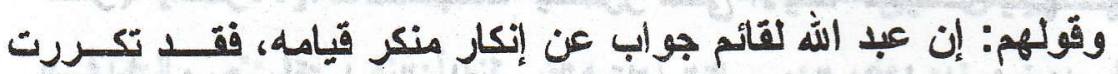

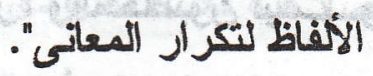
ومن هنا نعم أن العرب لاحظت أن يكون الكلام بمقار الحاجة، لازئدا

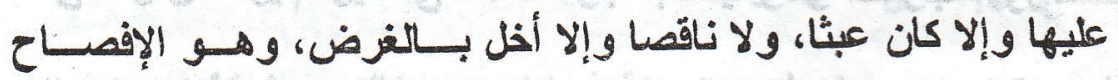
والبيان ونعلم أيضا أن المخاطب لا يخلو من أن يكون من ثلاثة. 1-خالى الأهن من الحكم، ومن التردد فيه، وعندئذ يلقى إليه الكـــلام

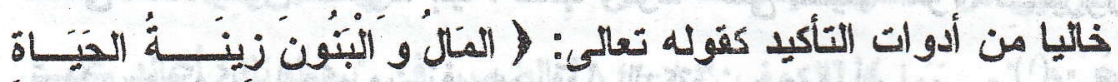

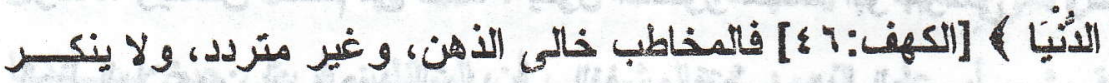

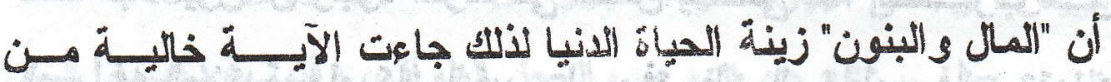

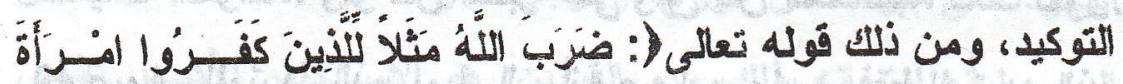

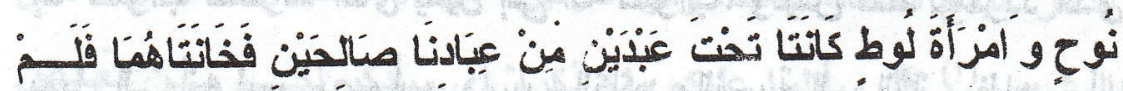

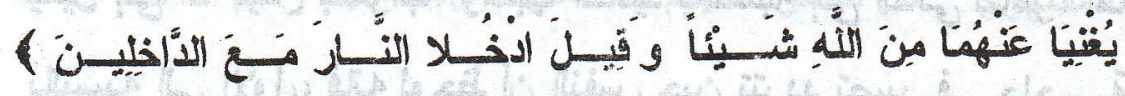
[التحريم: • 1] هذا مثل ضربه الله تعالىى لامر أتين كـــافرتين خـائنتين

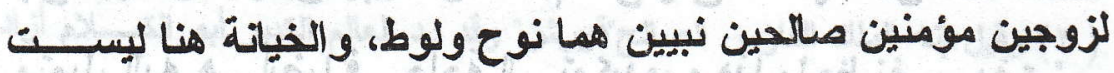
الزنا، لأن زوجات الأببياء لا يقعن فى هذه الجريمة، وخيانة امر أة نوح

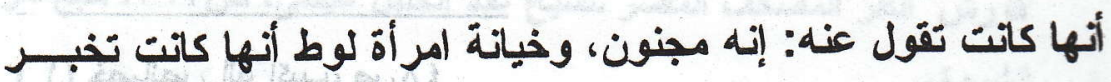




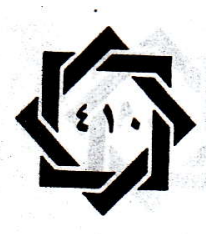

قومها عن ضيوفه، أو غير ذلك من الخياتات غــير جريــــة الزنــا،

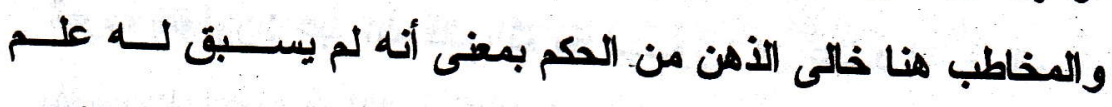
بفضمون الغبر، وخلو الذهن من الشئ يوجب استقراره فيه من غـير

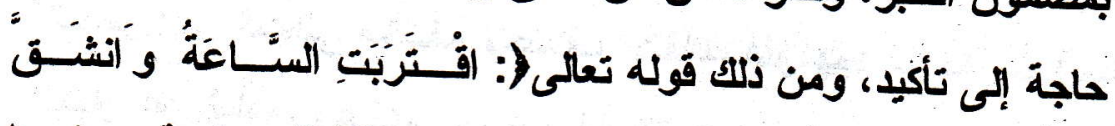

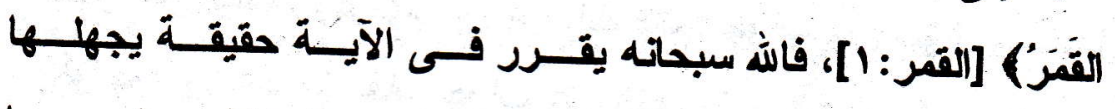

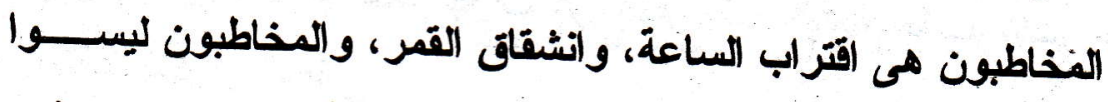
مترددين ولا منكرين لذا جاعت الآية خالية من التأكيل. وغير ذلك كثير فى القرآن الكريم، ويسمى هذا الضرب ابتدائيا وهو الضرب الأول. r-مترددا فى ثبوت الحكم وعدمه، سواء ترجع أحدهما على الآخـو أو

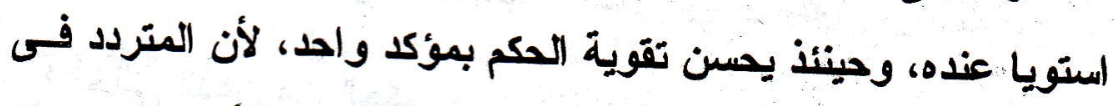
الشئ عادة يكون متشوقا إليه، طالبا وقوفه على حقيقة أمره، لـــيزول تردده، ويتمكن الحكم من نفسه، يقول الدكتور محمد أبو موسى (1):"وقد لحظ البلاغيون أن وجود التردد فى النفس يقتضى هذا الضـــرب مـن فئن الصياغة الموكدة، ولو كان الخبر على وفق ظن المخاطب، فأتت تقول: إنه صواب للمتردد الذى يميل إلى أنه صواب، وليس فقط للمتردد الذى كي يعيل إلى أنه ليس، بصواب، وسبب التأكيد بالنسبة إلى الثانى ظاهر، أما

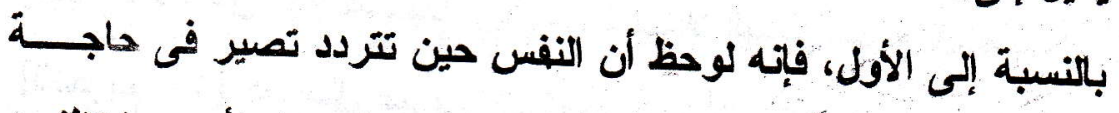

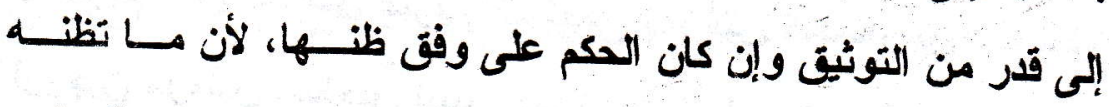

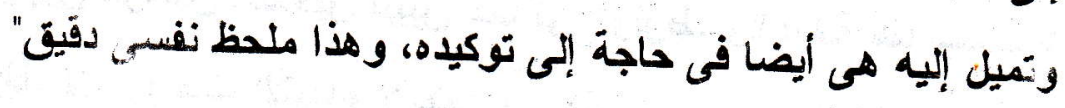




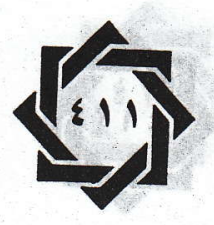

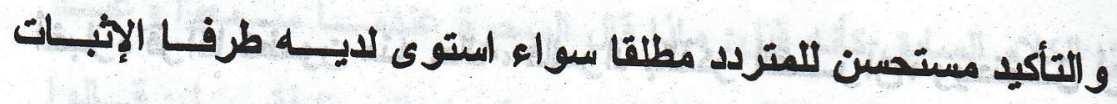

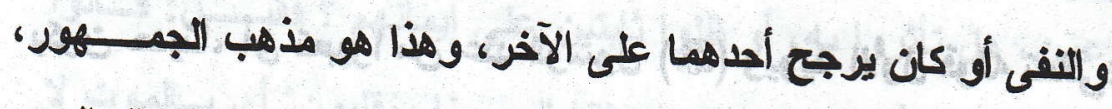

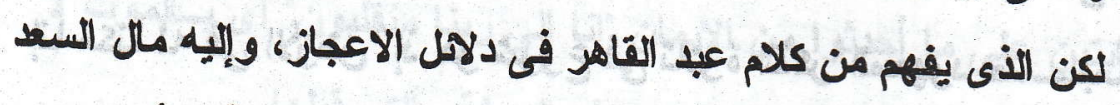

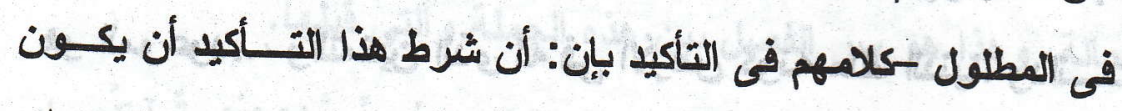

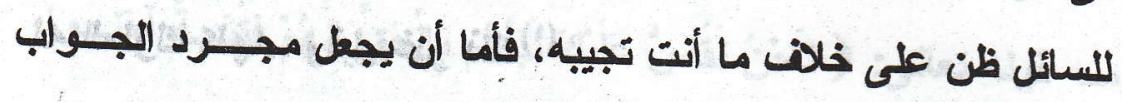

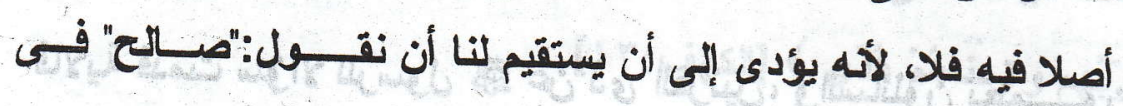

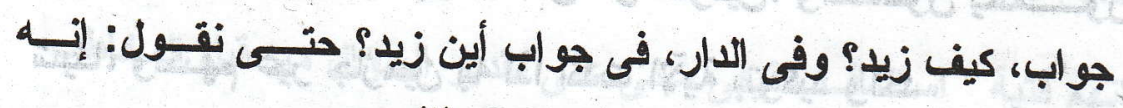

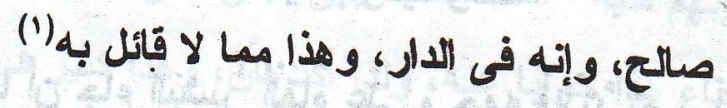

ويكثر هذا النوع إذا كاتت الجملة جوابا عن سؤال سواء كان صريحـا

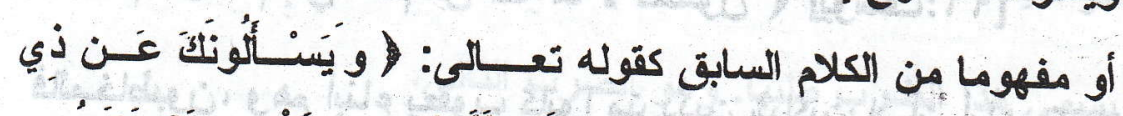

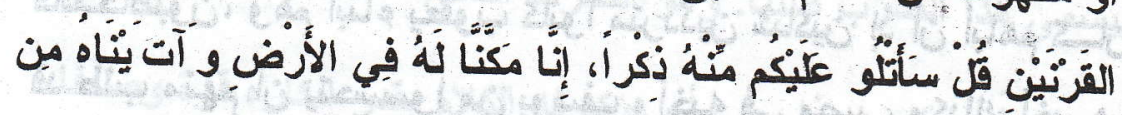

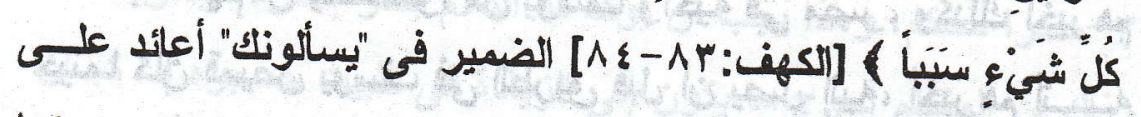

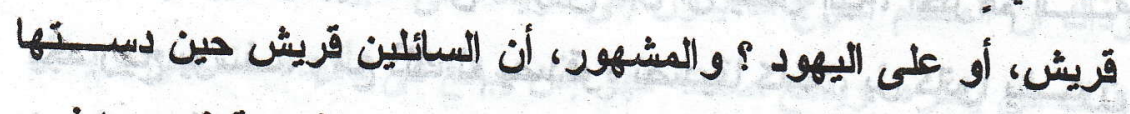

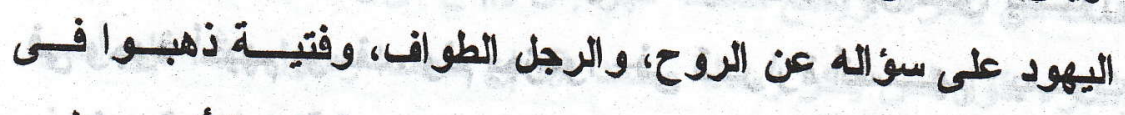

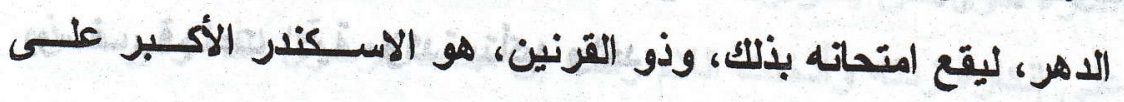

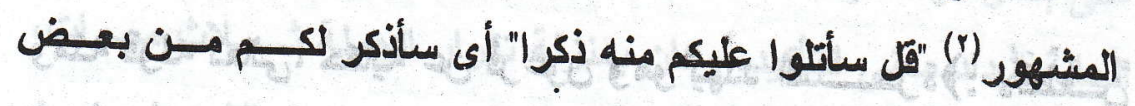

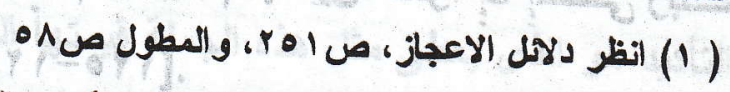

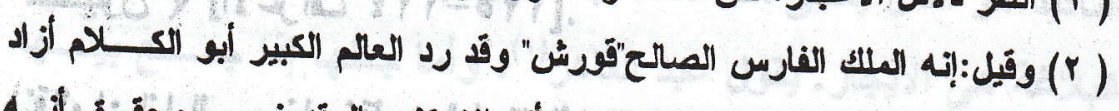

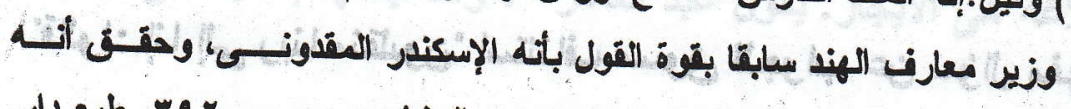

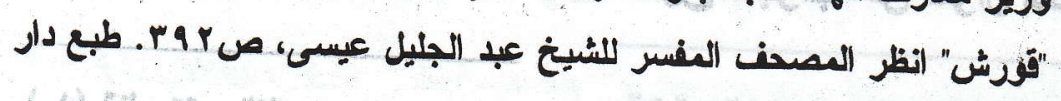




\section{相}

أخبار ه قرآنا تعمون منه حاله، فالمراد بالذكر القــــــآن، ويحتــل أن

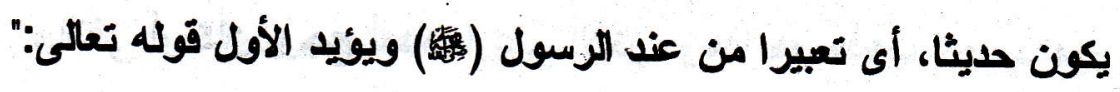
إنا مكنا له فى الأرض" إذ مو شروع فى تلاوة الأكر المعهود حســبما

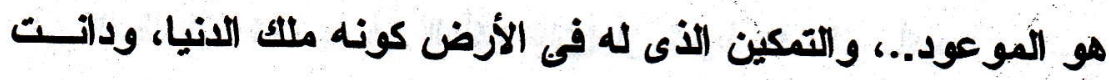

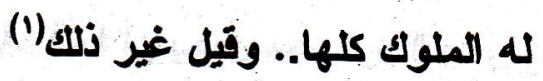

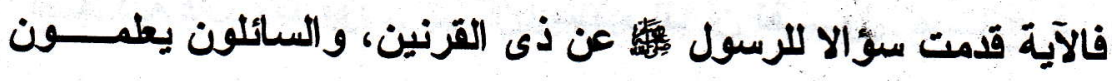
شيئا، ولكنهم غير جازمين به لذا أكدت الآية بتوكيد واحا

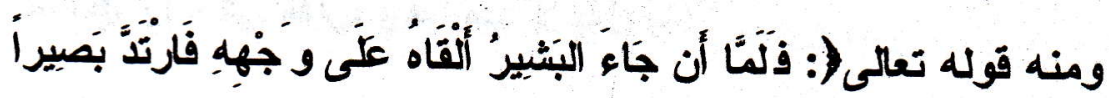

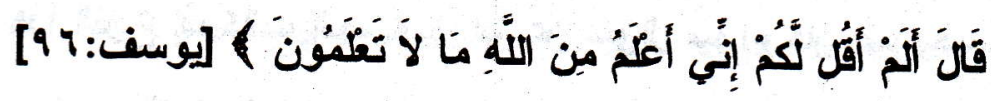
فالمخاطبون، وهم أبناء يعقوب كانوا مترددين شاكين إذ أن أباهم كــان قد طلب منهم أن يتحسوا من يوسف وأخيه فى مصر ، وكنلك أخبرهم

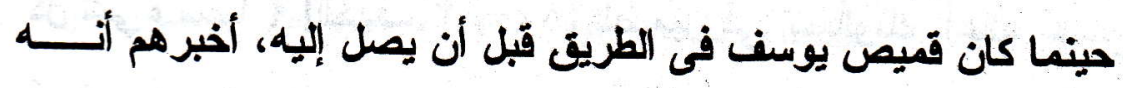
يجد ريع يوسف، ومع ذلك لم يصدقوه تصديقا كاملا، بل كاتوا يشكون

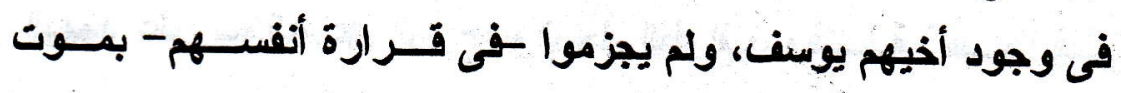

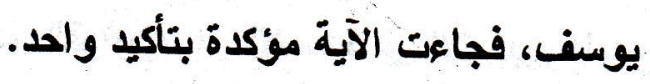

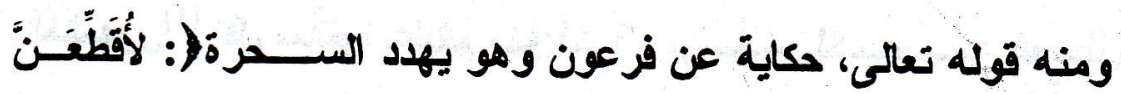

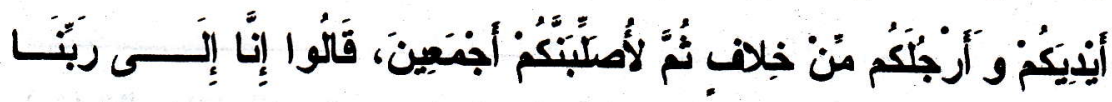

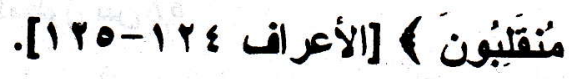

"تالوا: إنا إلى ربنا منملبون" استئناف مسوق للجواب عن سؤال مغهوم 


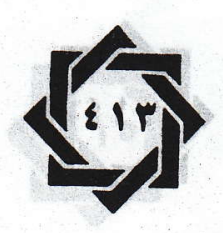

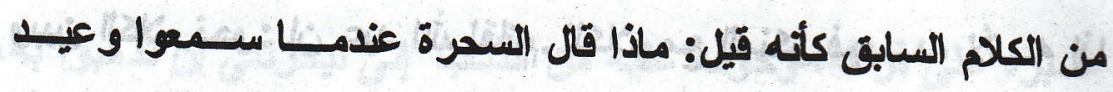

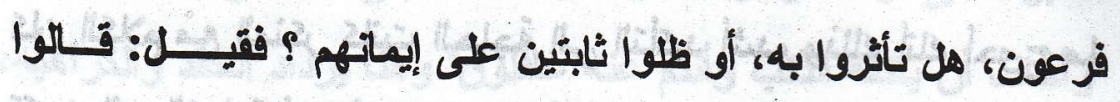

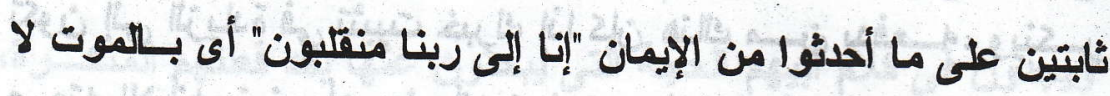
محالة، وهذا هو سر الفصل بين هذه الجملة والتى قبالها.

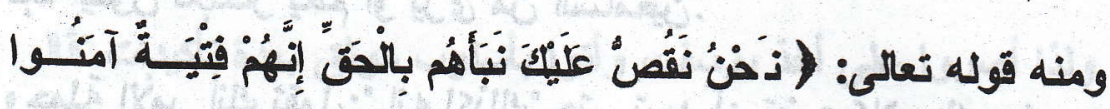

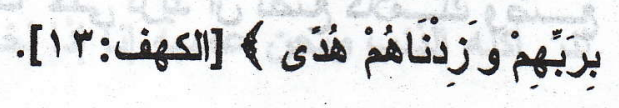

"إنهم فتية " اسنئناف حقيفى مبنى على تقدير السؤال من قبل المخاطب

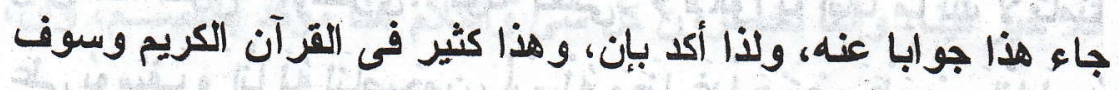
أذكر شيئا منه عندما أتحدث عن تنزيل غير السائل منزلة السائل.

$$
\text { ويسمى هذا الضرب طلبيا. وهو الضرب الثانى. }
$$

r-rنكرأ للحكم، وهذا يجب أن يؤكل له الكلام بقدر إنكاره قوة وضعفا،

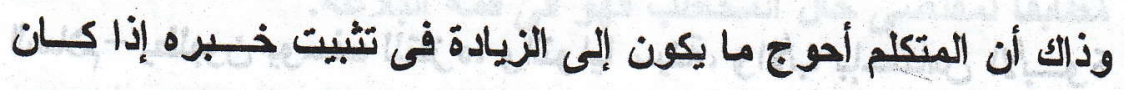

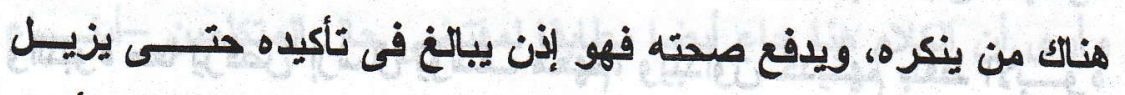

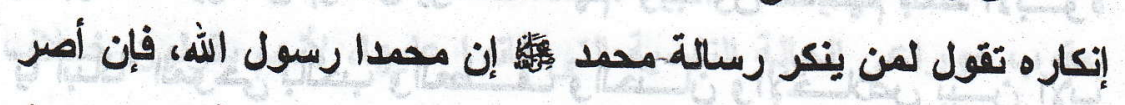

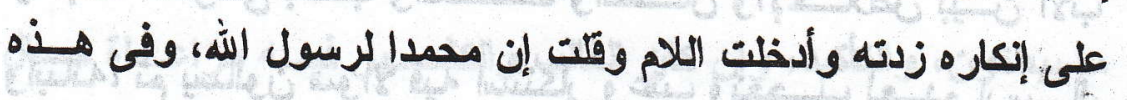

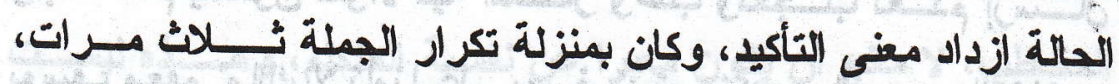

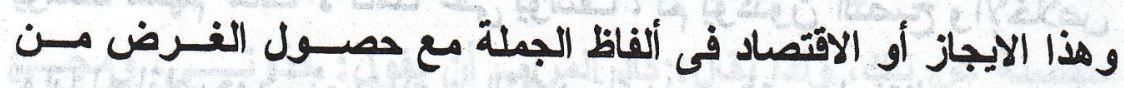

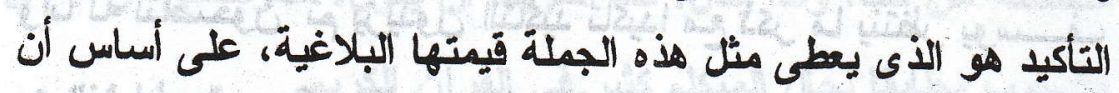

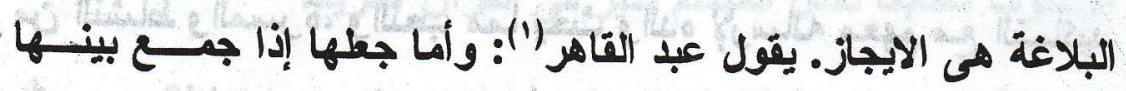




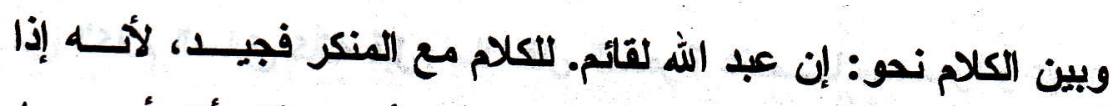

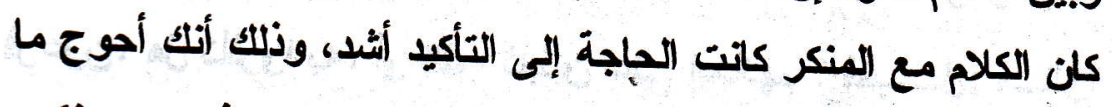

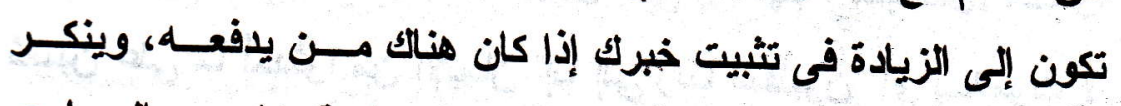

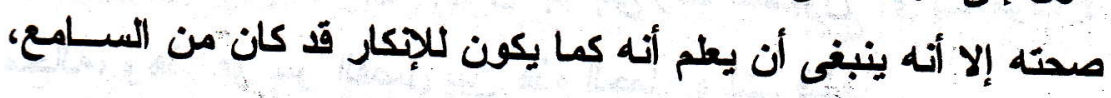
فإتها يكون للإنكار يعلم أو يرى من السامعين.

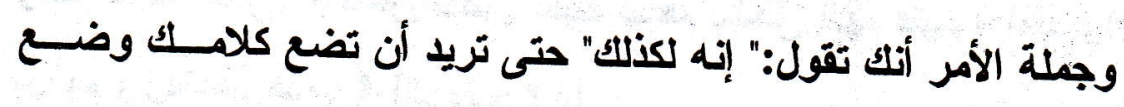
من يزع فيه الإكار.

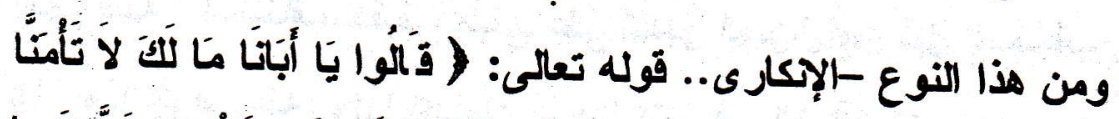

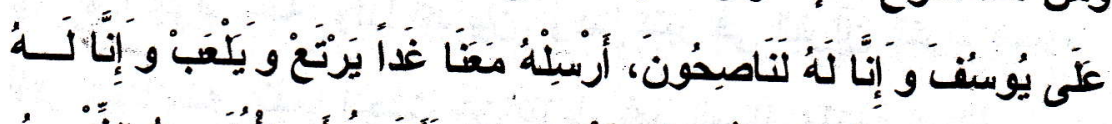

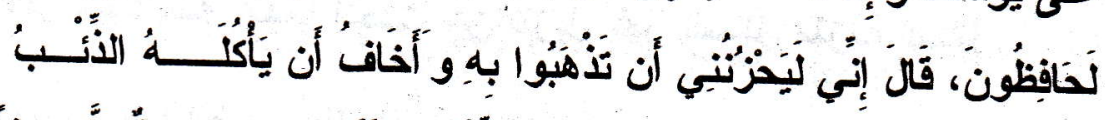

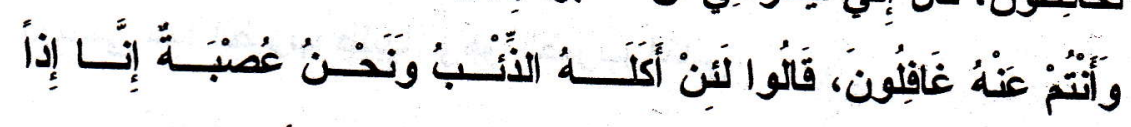

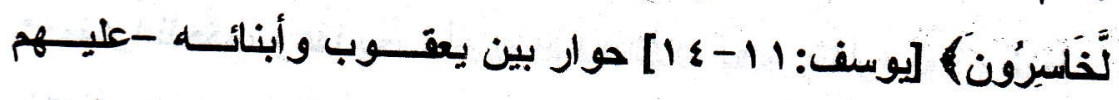

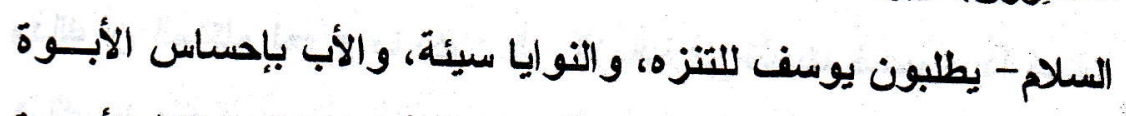

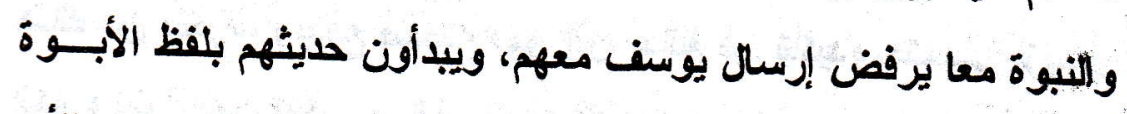

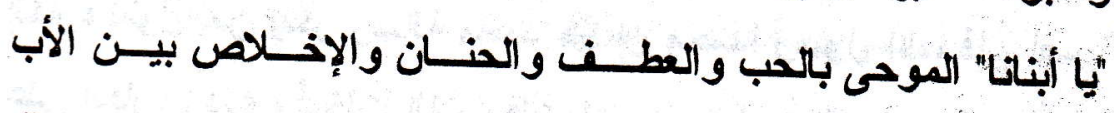
وأبنائه، ثم يسألون سؤالا فيه استنكار وعتب وتعجــب لعــم إرســال يوسف معهم "مالك لا تأمنا على يوسف"، ثم يؤكدون النصح والإخلاص

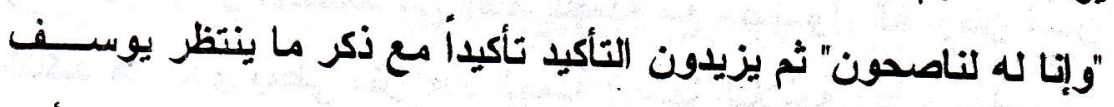
من النشاط والمسرة، واللعب مما يحث والده لإرساله معهم ميع التـأكبا

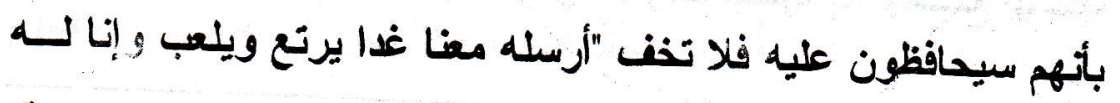
لحافظون" ولكن يعقوب - بليه السلام - يرفض ويعلل عدم إرساله بقلة 


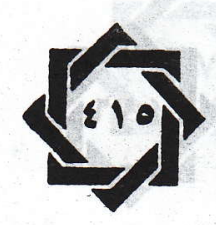

صبره على فراله، وخوفه عليه من النئاب "إنى ليحزننى أن تذهبو ابه، وأخاف أن يأكله الأتب وأتتم عنه غافلون" وهنا يزداد الحتّ والكراهية، ويجدون فى كلام أبيهم الحجة التى يبحثون عنها بع فعتهم المنكــرة، وكأن أباهم لقته الغذر، ووجدوا في كلامه الجواب الذى بيحقون عنه، ولذا. أصروا على أخذ يوسف، وأتوا بأسلوب موثق بعة تأكيدات "قالوا

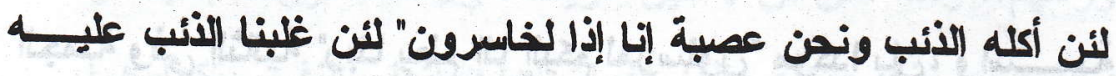

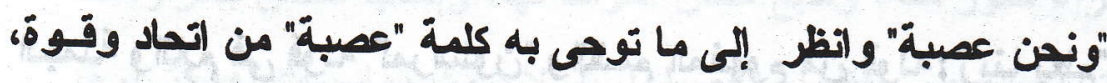
فلا خير فينا، وإنـا لخاسرون كل شئ والكلام هنا مؤكد بالقســم، وإن، واللام، وإسمية الجملة، حتى يصلون إلى غرضهم الأى يسعون إليه. والمخاطب يعقوب -عليه السلام- وهو يرفض وينكر إرسال يوسـلـف معهم، فجاء الأسلوب مؤكدا له بأكثر من مؤكد، وبهذا يكون جاء الكلام مطابقا لمتضى حال المخاطب فهو فى قمة البلاغة. وأرى أن الكلام هنا جاء أيضا مطابقا لمقضى حل المتكلمين -أبنــاء

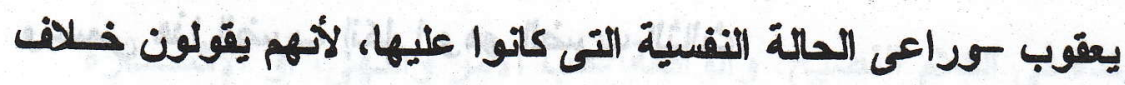

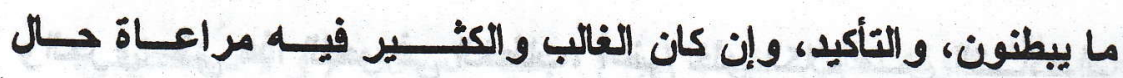

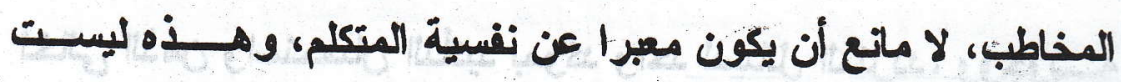

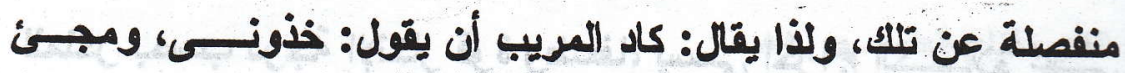
الأسلوب مطابتا لحال العتعلم كثير فى القرآن الكريم. ومن الآيات المطومة فى ذلك ما قصل اله - عز وجل - حكاية عن رسل

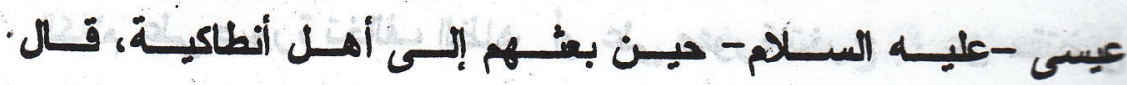




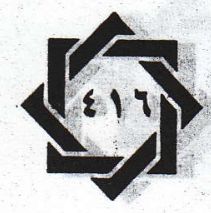

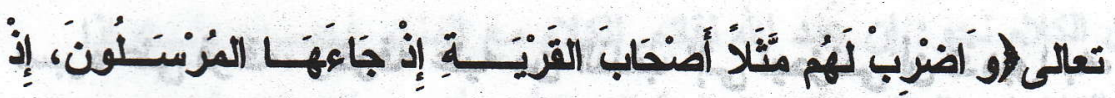

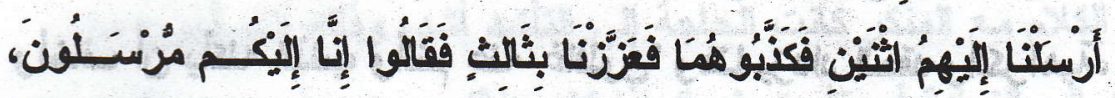

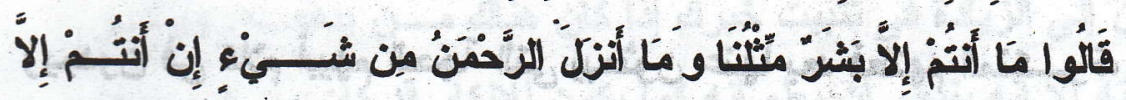

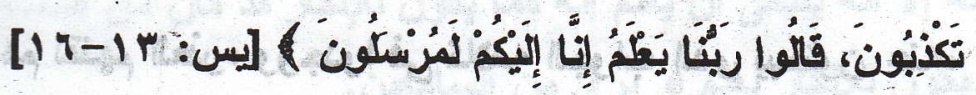

حيث قالوا فى المرة الأولى:"إنا إليكم مرنطون" ومؤكدا بـإن وإبـمية

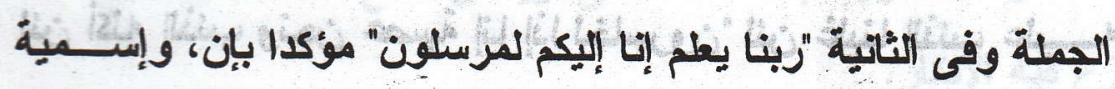
الجملة واللام في قوله "مرسنلون" والقسم المفهوم من قوله:"رينا يطم"

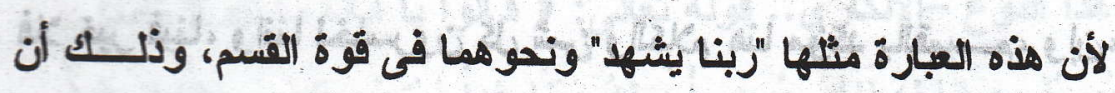

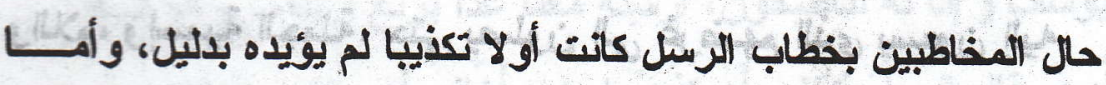
الحالة الثانية فكاتت تكذيبا على سبيل الكناية التئ هى كدعوى الثنـئئ

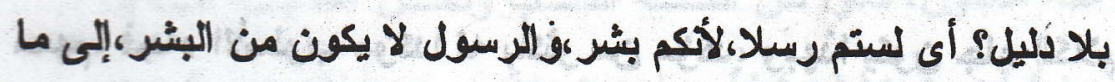

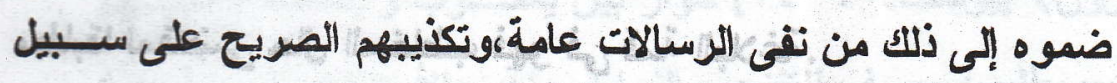
القصر والتضصيص مما يضاعت من أمر تكنيهم وإنكار هم كما وكيفا.

\section{ويسمى هذا الضرب إنكار اوهو الضرب الثالث.}

والجرى على هذا النحو فى الخطاب، أغنى خلو الكلام مـن التـاكيلات

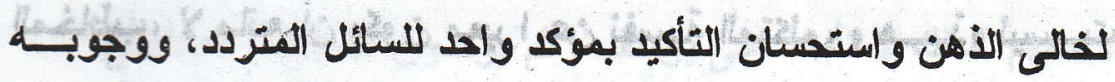

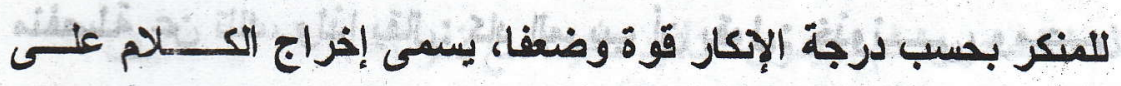

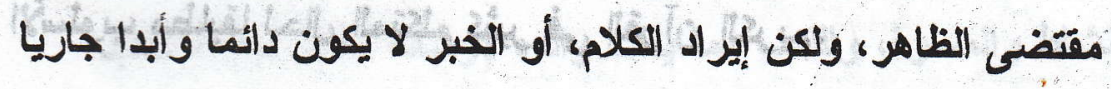

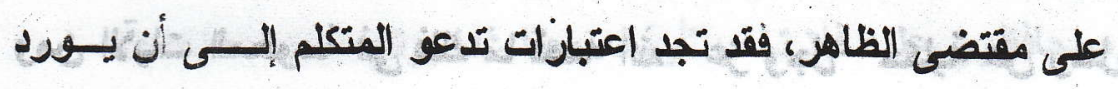

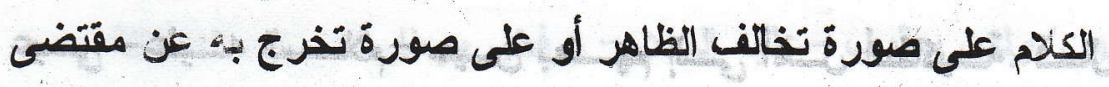




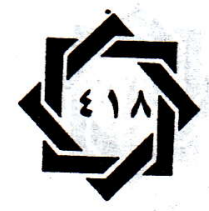

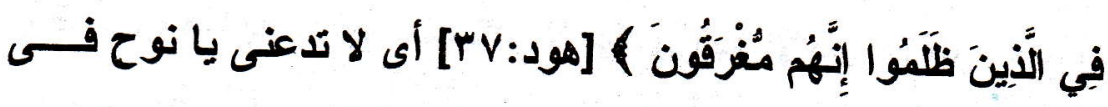
شأن قومك، واستدفاع الغذاب عنه بشفاعتك.

فنوح -عليه السلام- خالى الذهن عن الحكم الذاص بالظالمين، وكسان

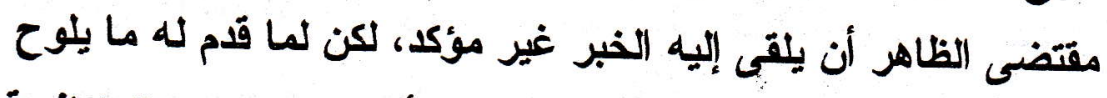

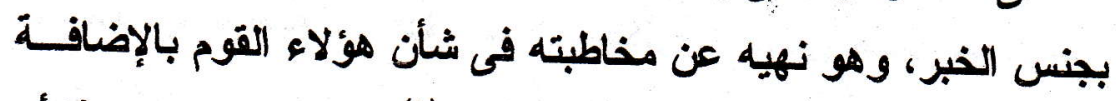

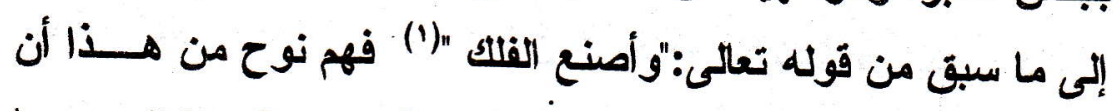

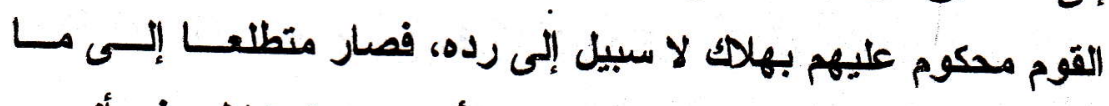

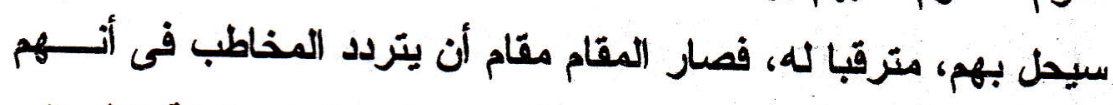

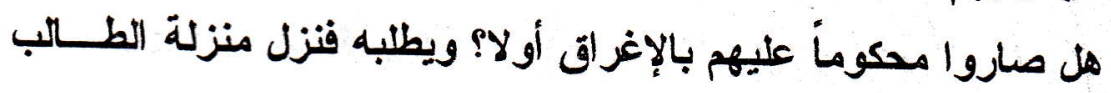

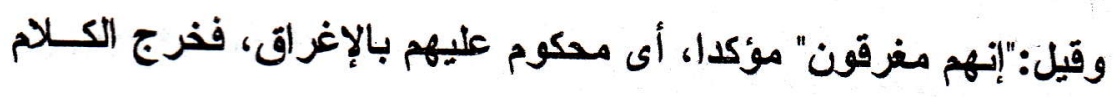
على خلاف مقتضى الظاهر

ويلاحظ أن "إن" هنا أفادت بجاتب التأكلي، والربط بين الجملتين، التعليل

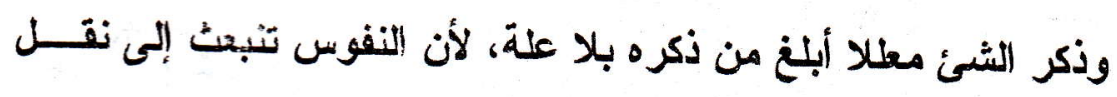

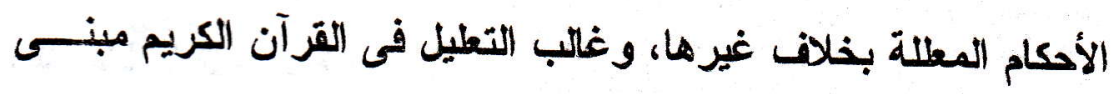

( ) إذا نظر إلى "ولا تخاطبنى" فقط كان هناك إشارة إلى جنس الخبر، وإذا نظرنـا

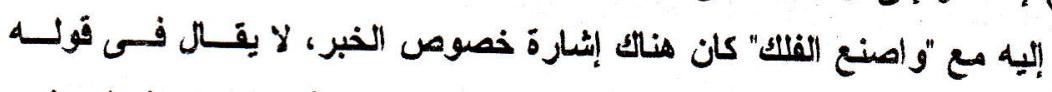

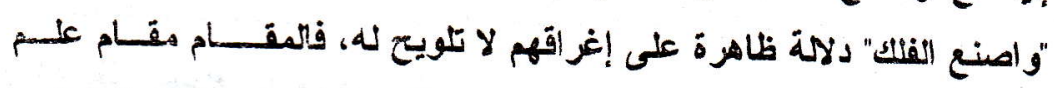

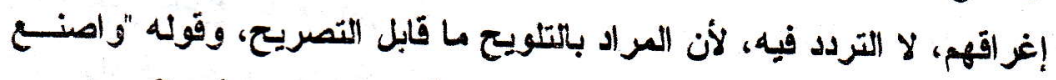

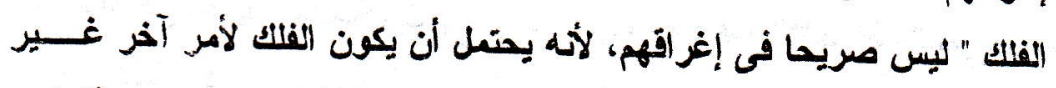

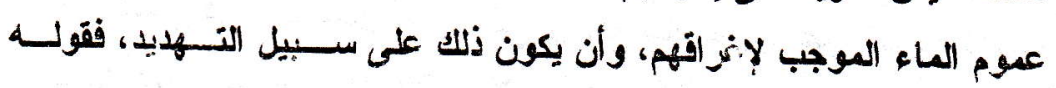

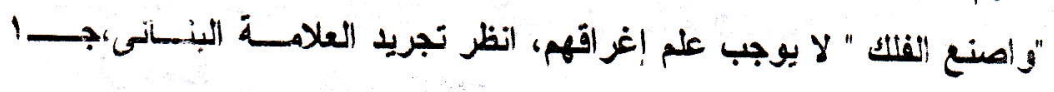




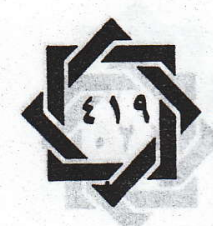

على تقدير جواب سؤال اقتضته الجمله الأولى، وهو سؤال عن العلة(1) وهذا هو سر الفصل بين الجملتين، وهو ما يعرف فى البلاغة "بثَــبه كمال الاتصلال.

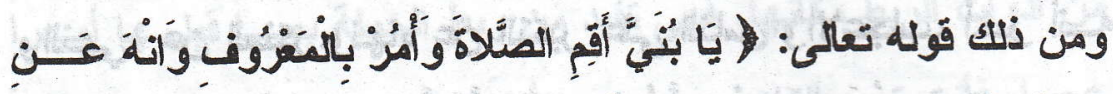

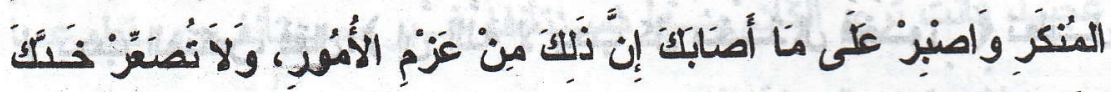

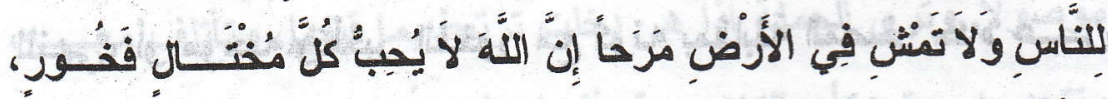

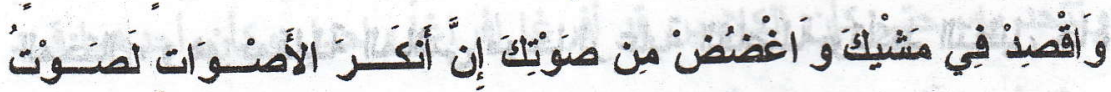

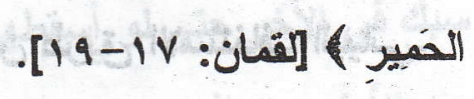

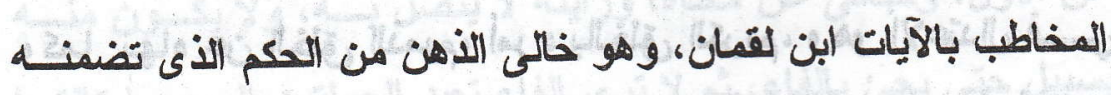
الخبر وكان مقتضى الظاهر أن يلقى إليه الكلام خاليا من التأكيد، ولكن الكن

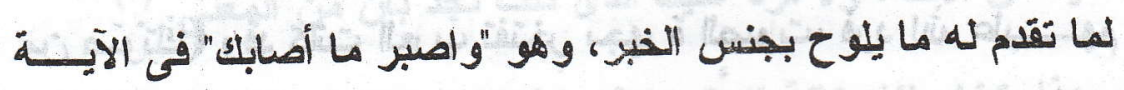

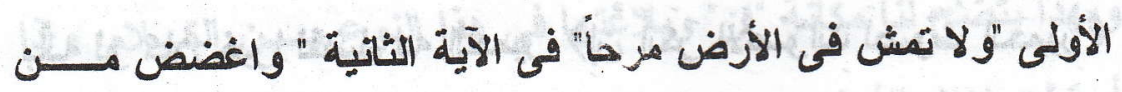

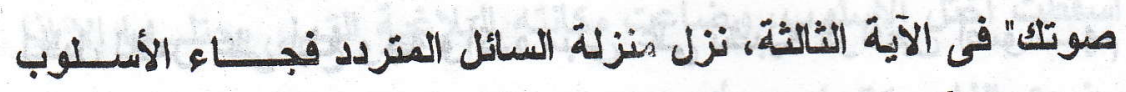

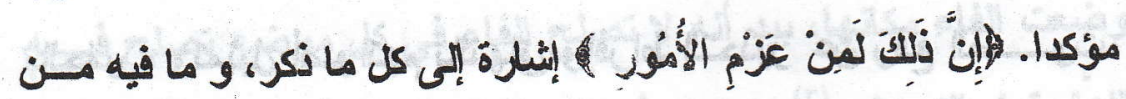

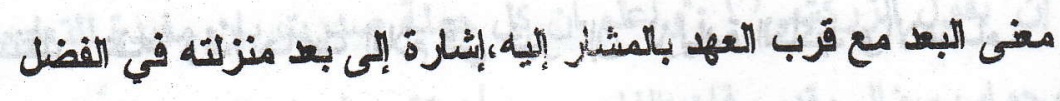

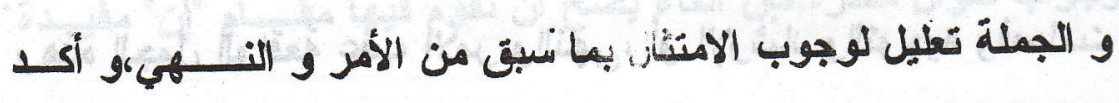

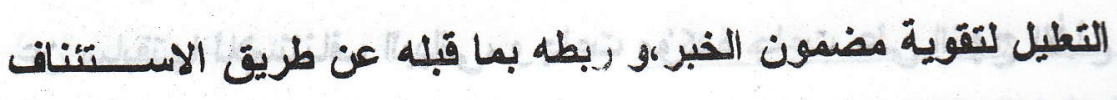
البياتي المؤكلهو هذا هو سر الفصل. 


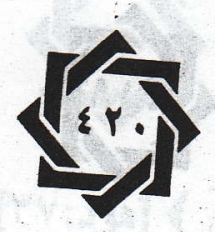

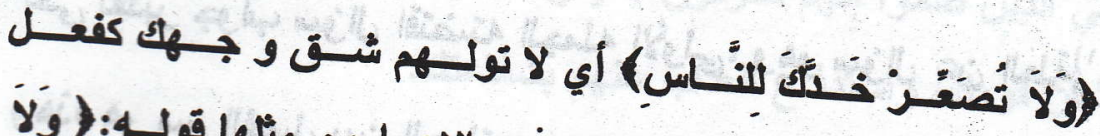

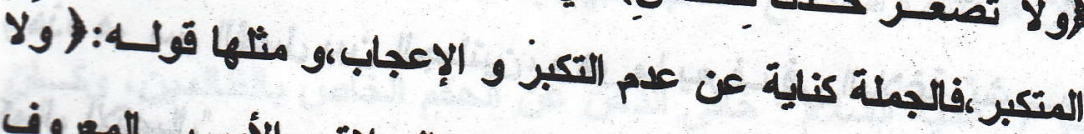

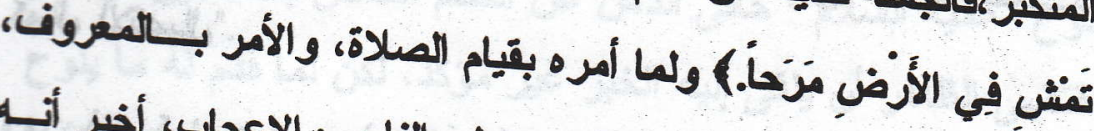

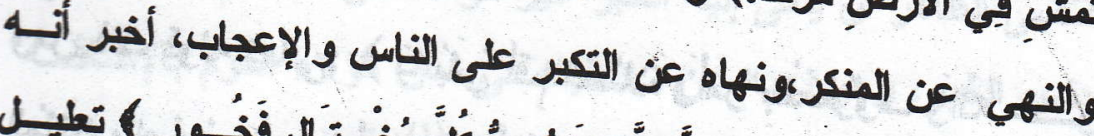

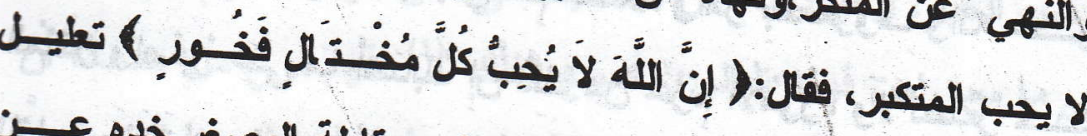

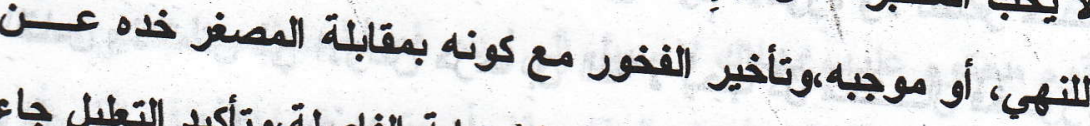

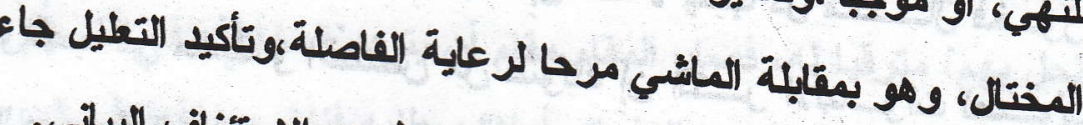
لتقوية مضسون الثبر وربطه بعا قبله عن طريق الاستئناف البياتي.

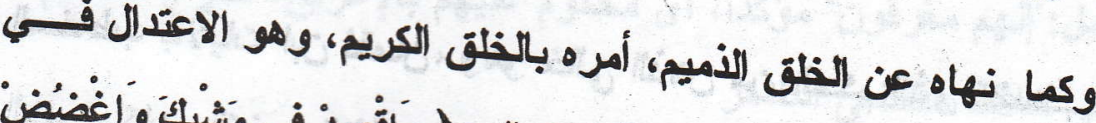

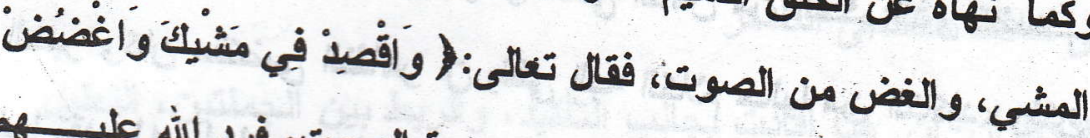

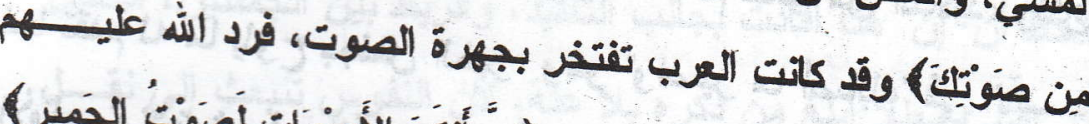

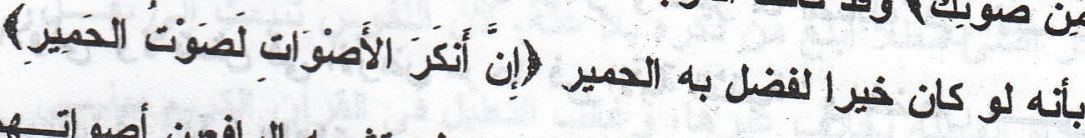

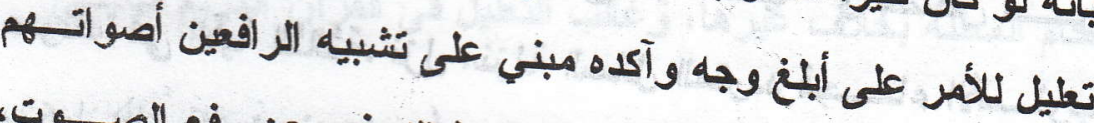

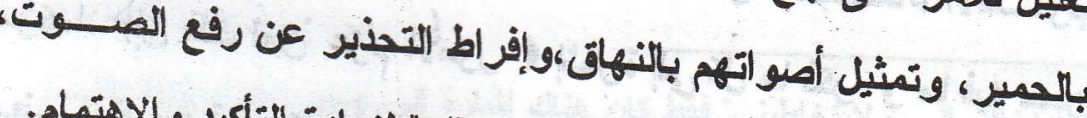
والتنفير عنه، ولذا جاءت اللام في خبر "إن" لزيادة التأكيل والاهتمام.

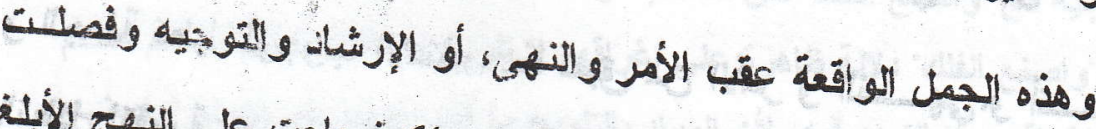

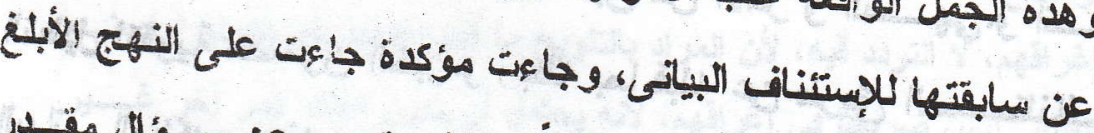

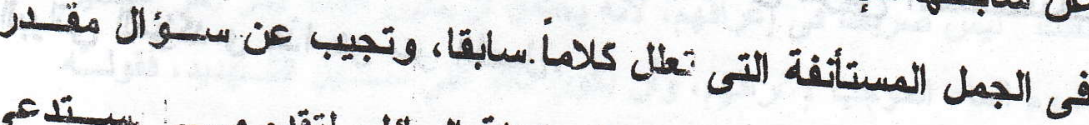

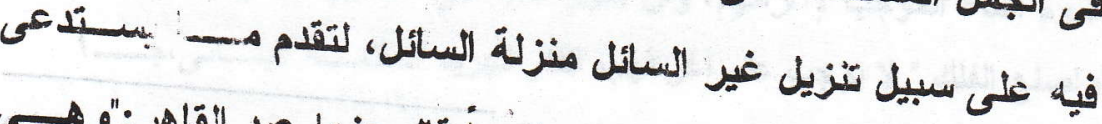
يؤالا، وهى فى القرآن الكريم كثيرة جدأ قال عنها عبد القاهر :"ولهى 


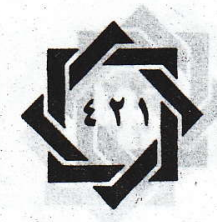

على الجملة من الكثرة بحيث لا بلركها الإحصاء"((1)

و"إنَ" فى مثل هذه المواقع بجانب إفادتها التاكيد و التعليل تربـــ بـــن

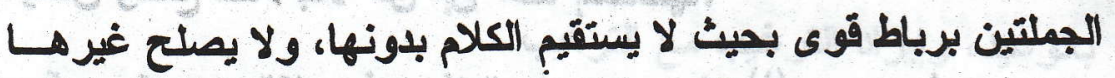
من أدوات الربط مكانها، فهى تفيد من ربط الجملة بـــا قبــــها أمــراً

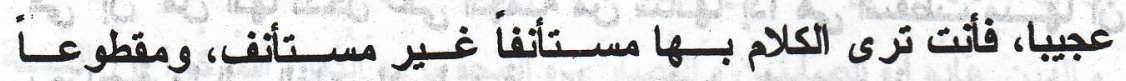

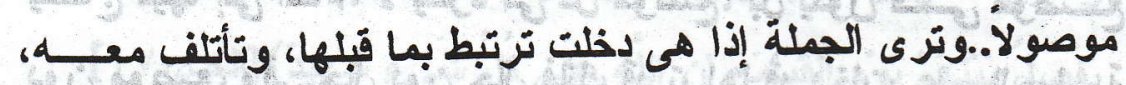

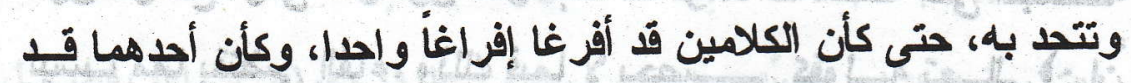
سبك فى الآخر حنى لو أسفطها في مثل ذلك رأيت الثانى منهما قد نبـأ

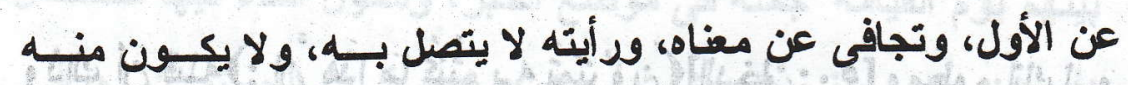

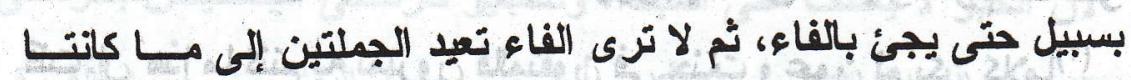

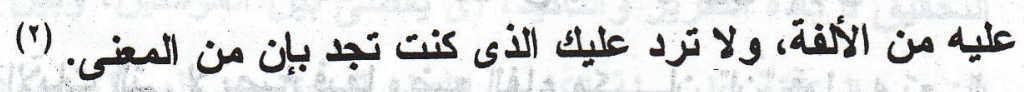
وبهذا يتضـح لنا مكانة "إنَّ" وبلاغتها في هذا النوع مـــن الكـلام، و إذا

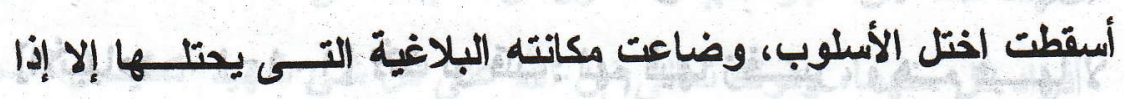

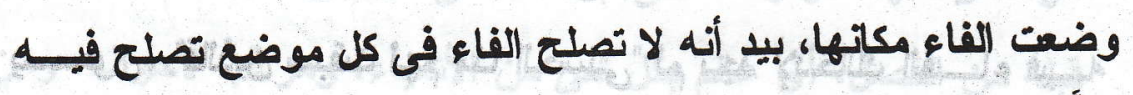
"إن" يقول الزركشى (ז) :"واعم أن كل جملة صدرت بإن مفيدة للتعليله،

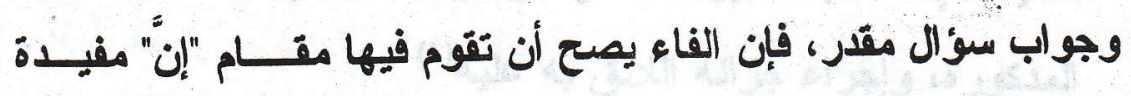

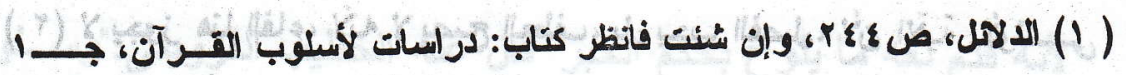
891-897ט r\&ru (r)

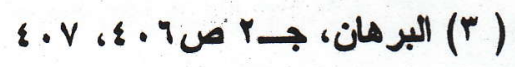




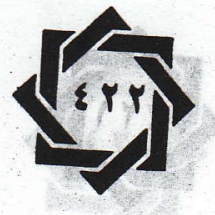

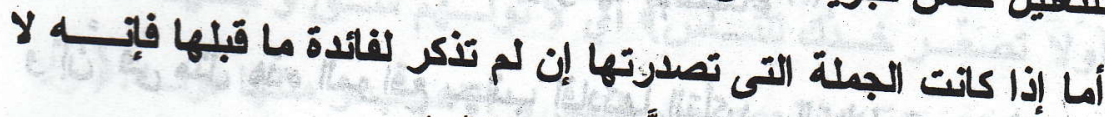

للتعيل حسن تجريدما عن كونها جوابا للسؤال. يكن وضع الفاء بدلا عن "إن" عند إسقاطها.

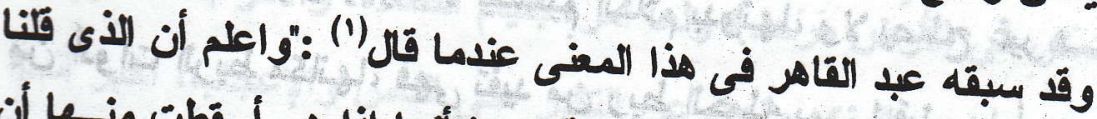

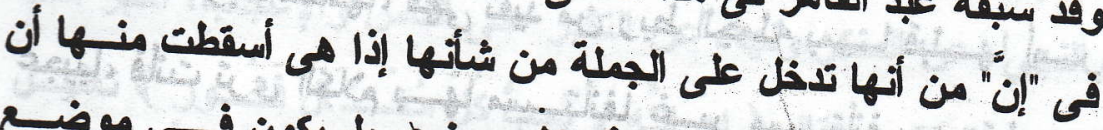

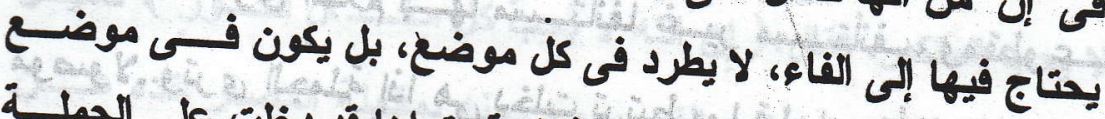

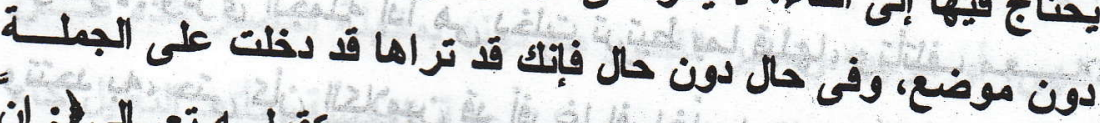

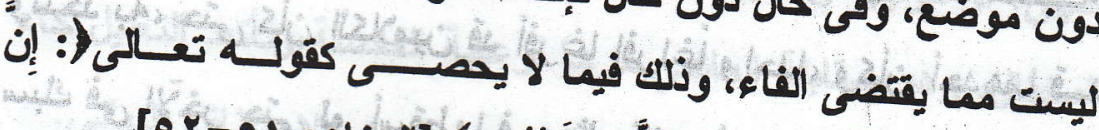

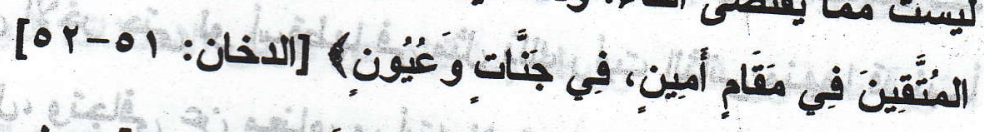

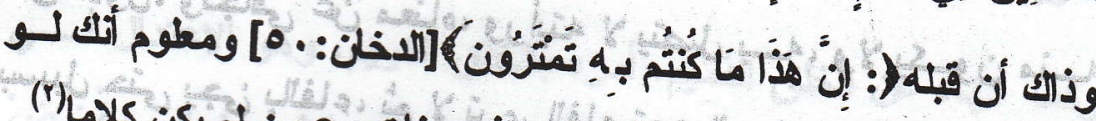

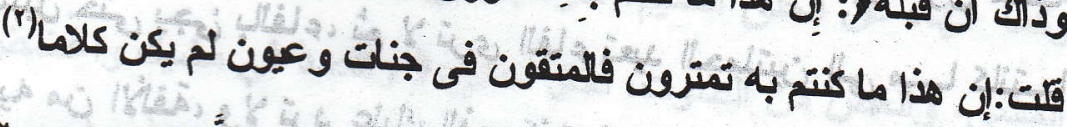

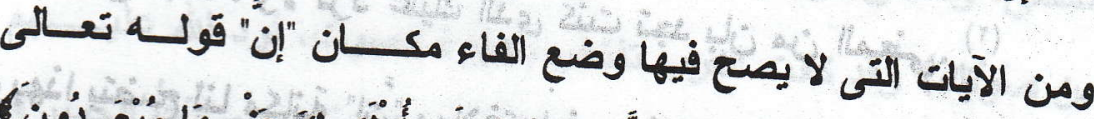

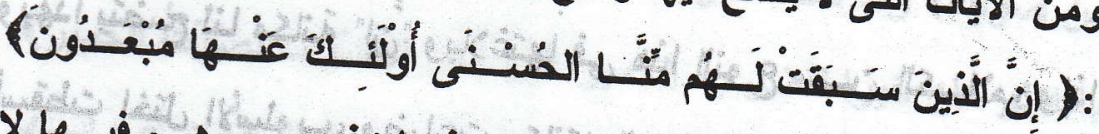

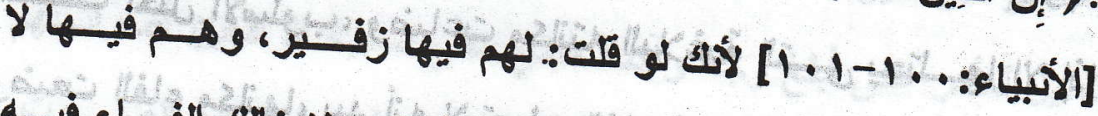

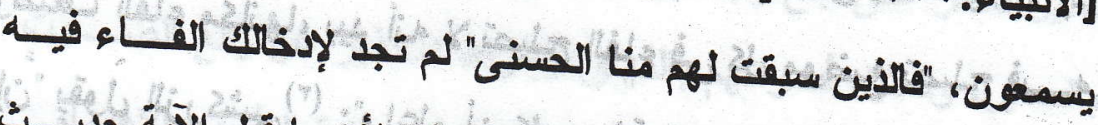
وجها، لأحة لا يصع العطف، بل يجب الفصل، لأن ما قبل الآية حديــــ

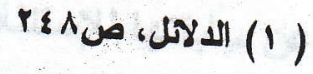

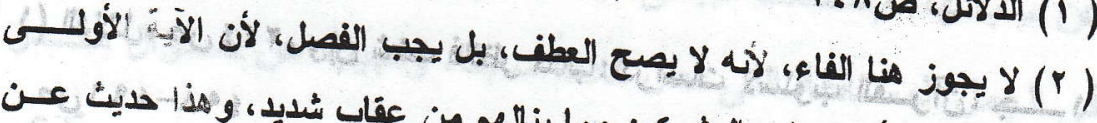

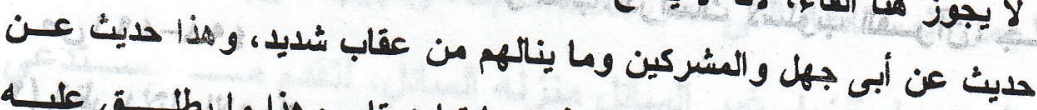

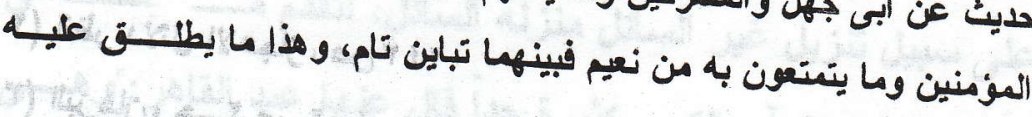
كال الانطاع. 


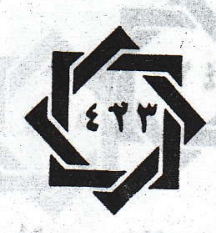

عن الكاقرين، وما يلقون من عذاب، ثم شرع فى بيان حال المؤمنيــنـ

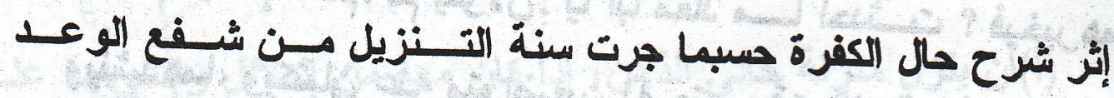
بالو عبد، وإيراد الترغيب مع الترهيب.

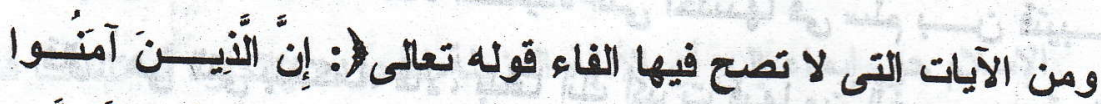

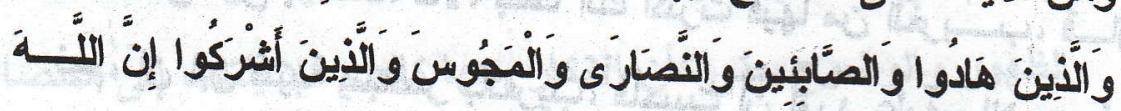

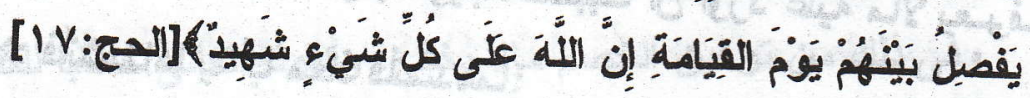
"الأين آمنوا" اسم "إن" وما بعده معطوف عليه، وقوله "إن الله يفصــل

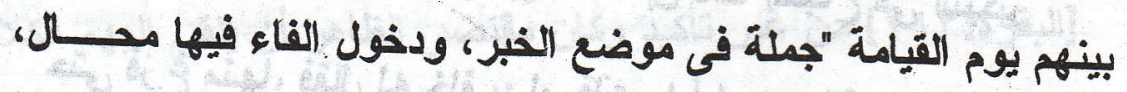

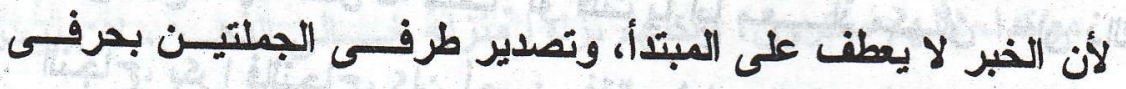
التحقيق لزيادة التقريز والتأكيد، أى يقضى بين المؤمنين، وبين الفـون الخمس المنفقة على ملة الكفر، بإظهار المحت من المبطل، وتوفيه كل

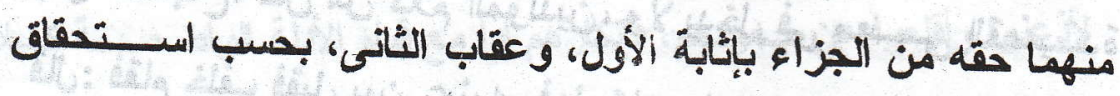
أفر اد كل منهما، وقوله تعالمى:"إن الله على كل شئ شهيد" تعليـلـل لهـيا.

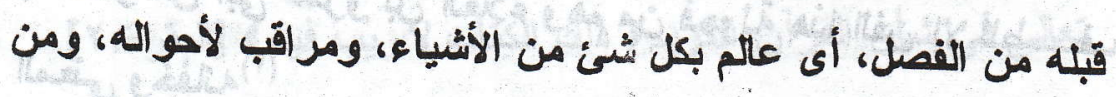

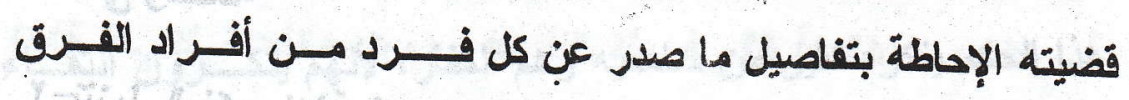
(المذكورة، وإجراء جزائه اللهق به عليه وهنا النوع من الكلام - أغنى تنزيل غير السائل منزلة السائل المتردد،

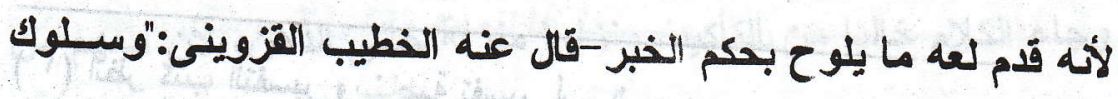

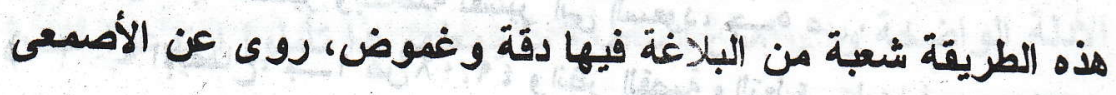




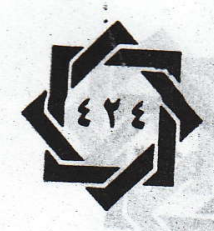

كال:كان أبو عمرد بن العلاء، وخلف الأحمر يأتيان بشــاراً فيسـلمان

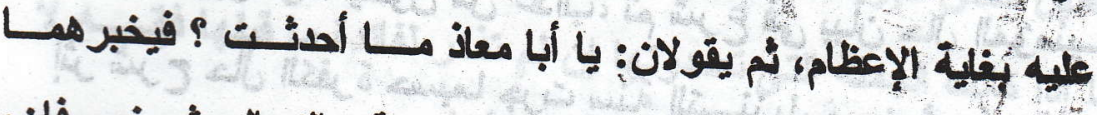
وينشا ولا، ويكتبان عنه متواضعين له حتى وقت الزوال، ثُم ينصرفان،

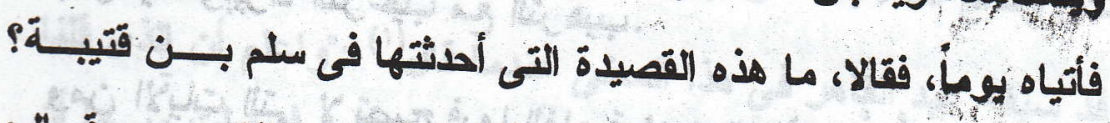

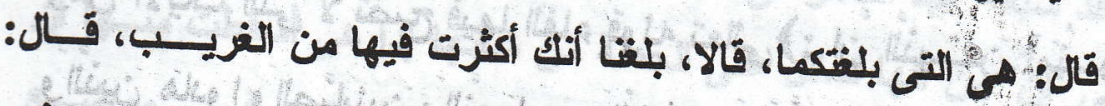

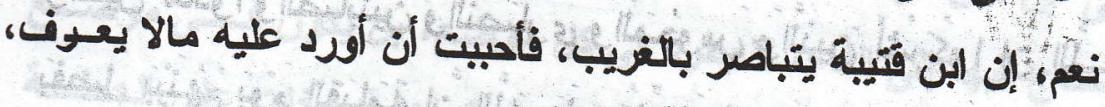

\section{قالا: فأسشدناها يا أبا معاذ فأتشده هما:}

بكرأ صاحبى قبل الهجير ** * إن ذالك النجاح فى التبكير

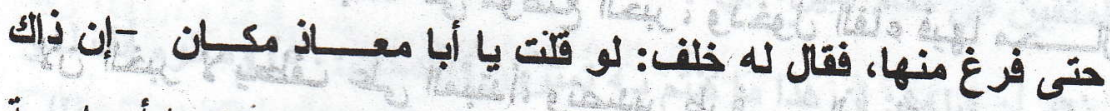

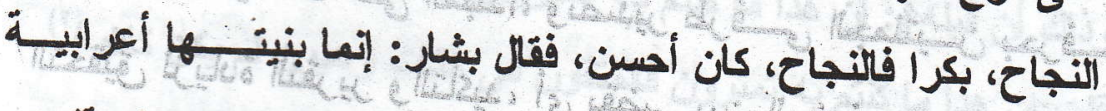

وحشية، فمتت: إن ذاك النجاح كما يقول الأعراب البإويون، ولو قلـت:

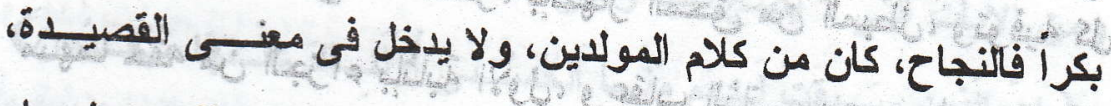
قال: فقام خلف فقبل بين عينيه، فهل كان ما جرى بين خلف، وبئهيار

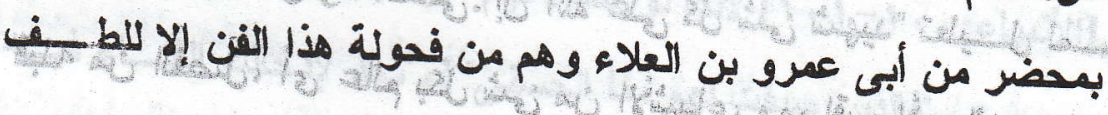

(المنفى وخفائه (r)

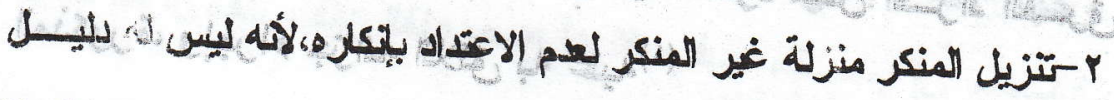

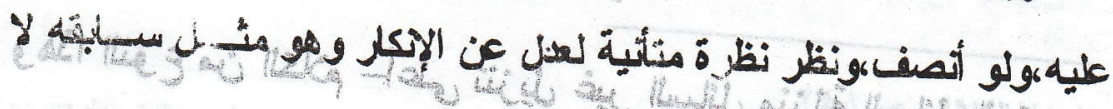

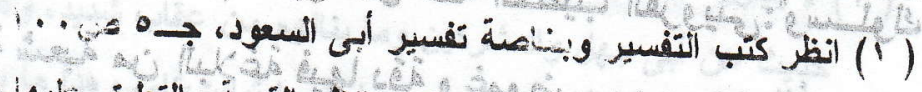

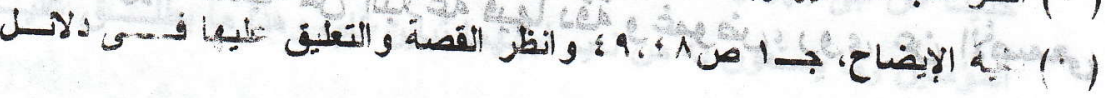

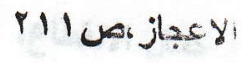




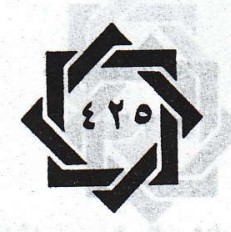

يهنى الليه إلا بصير بسيلسة الكلام،وهو منحصر فى صصرتين:

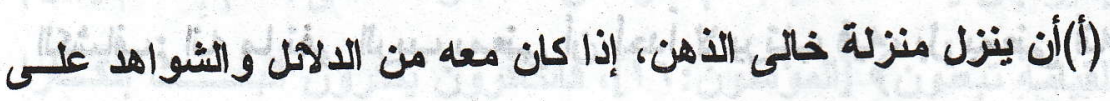

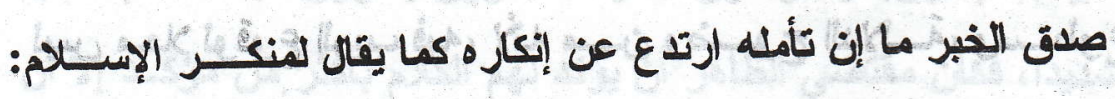
الإسلام حق إيماء إلى أن الأدلة المزيلة لجحودهو إنكاره قد تناهت فـى لئ الظهور والوضوح حتى كأن الانكار معها كالطظم فلا يلتفت إلى مقتضاه،

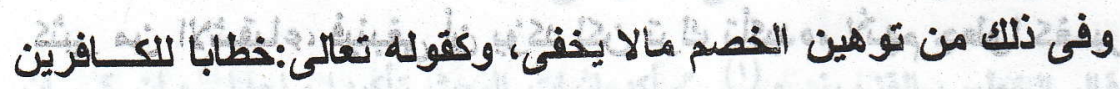

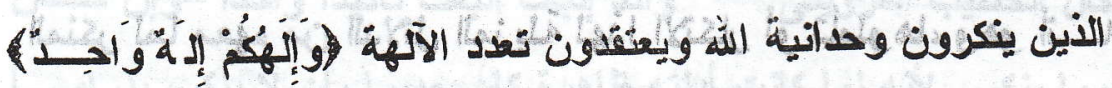

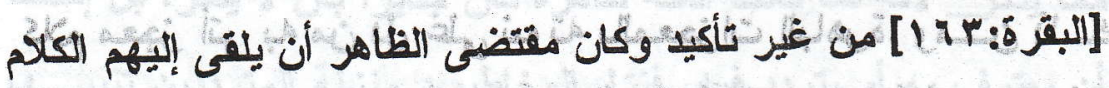

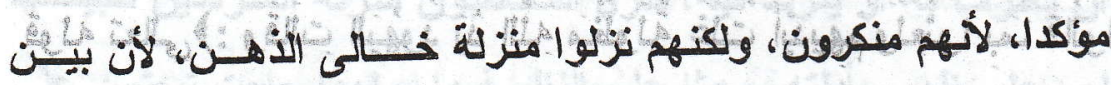

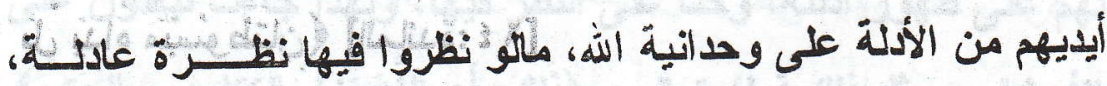

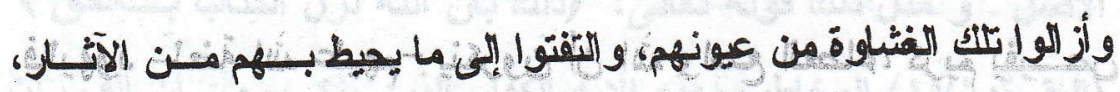

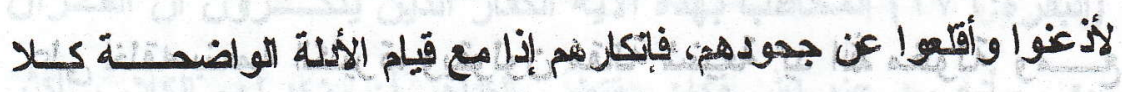

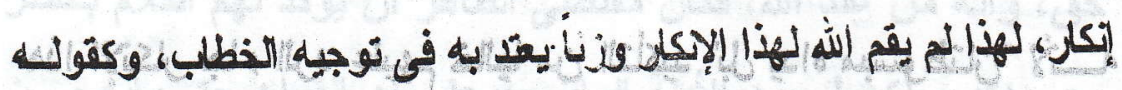

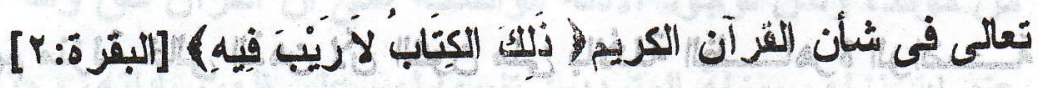

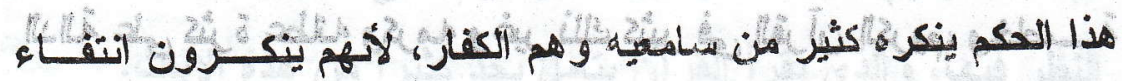

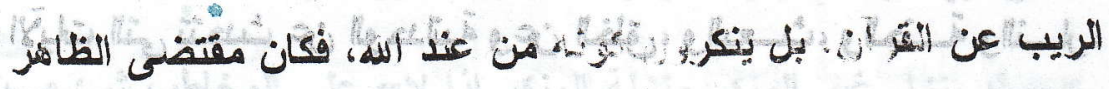

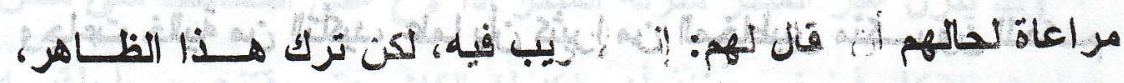

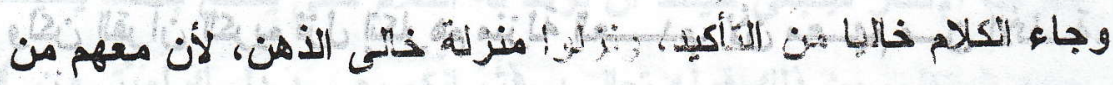

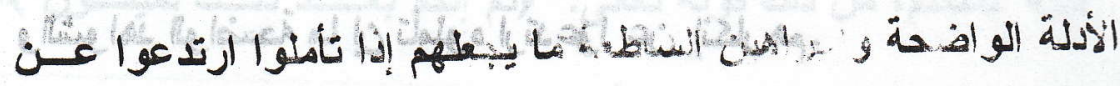

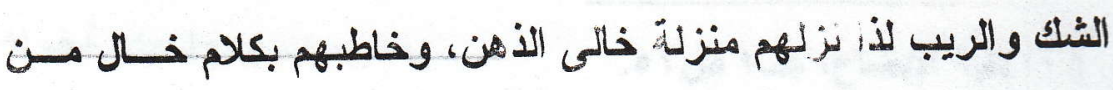




\section{进}

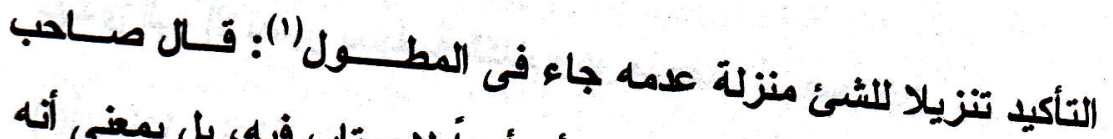

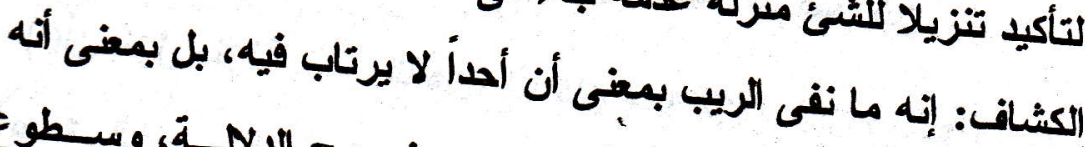

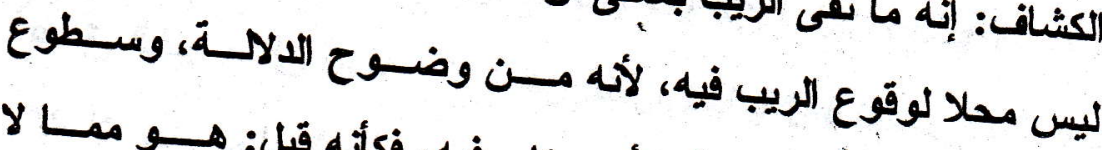

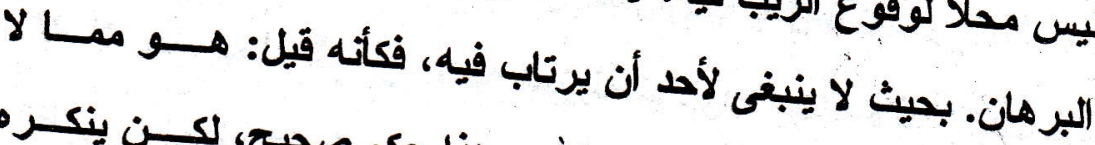

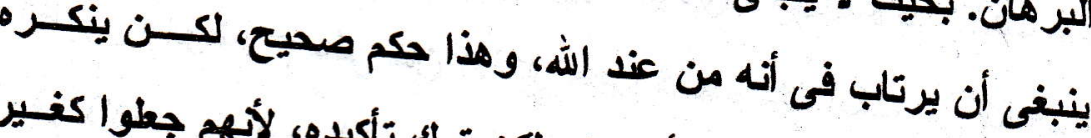

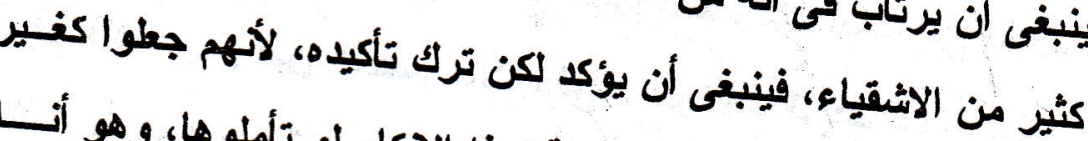

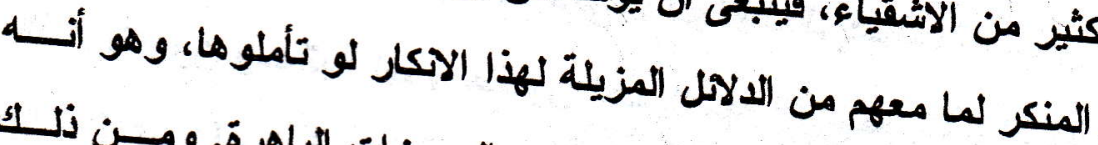

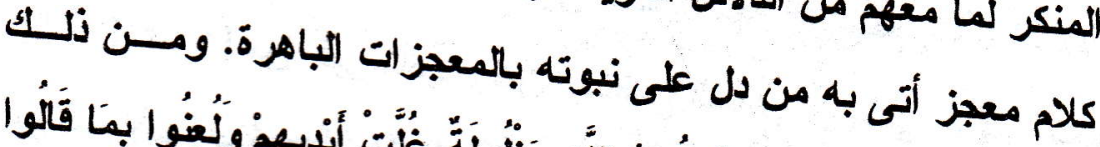

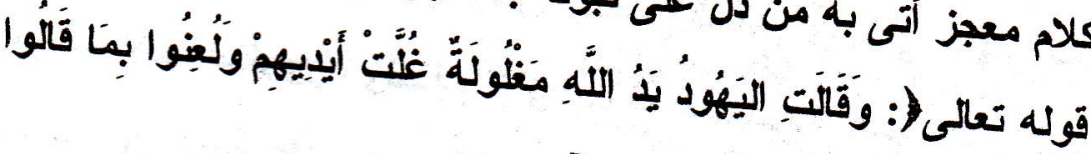

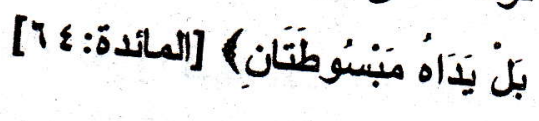

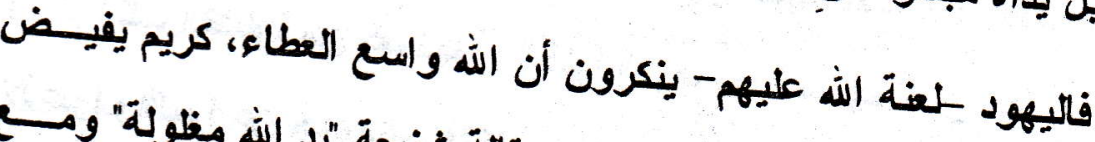

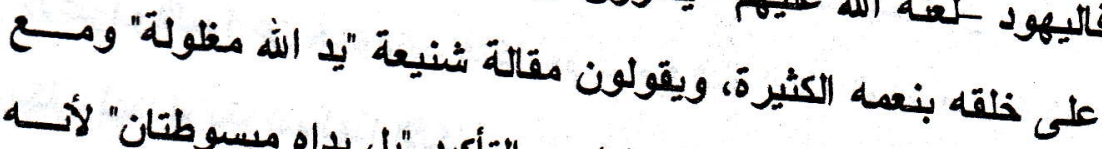

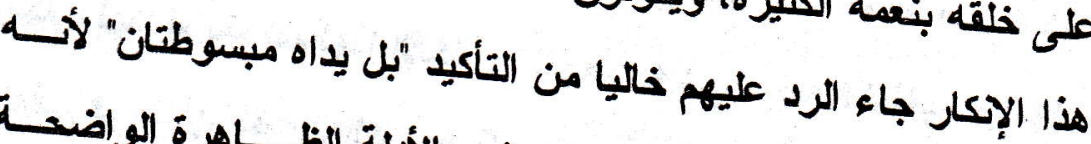

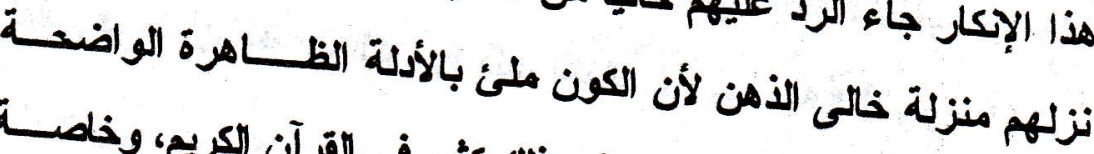

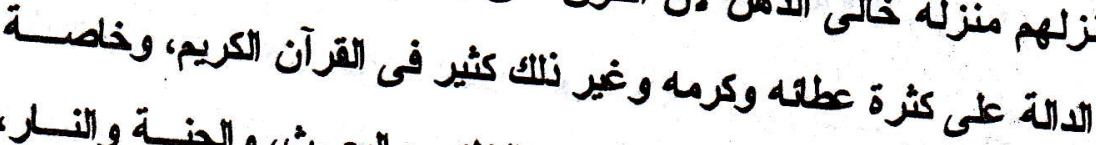

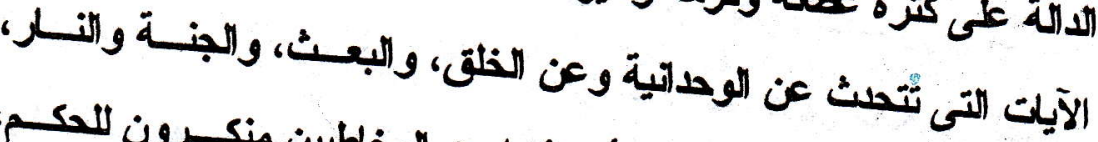

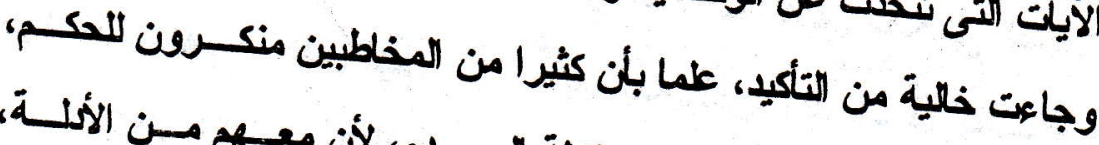

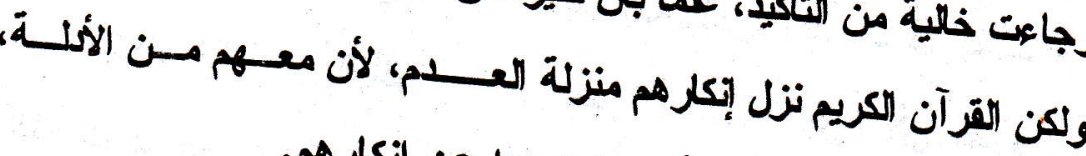
والشواهد الواضحة ما إن تأملوه ارتدعرا عن إنكار هم. 


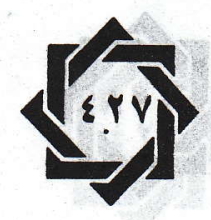

(ب)أن ينزل المنكر منزية السائل المتردد إذا كان معه من الأدلة كا هو

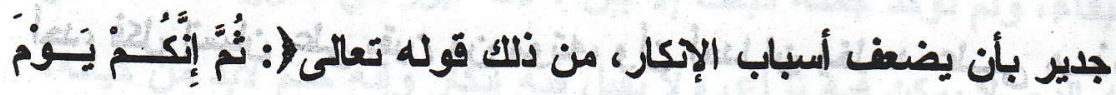

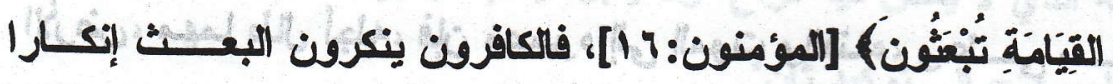

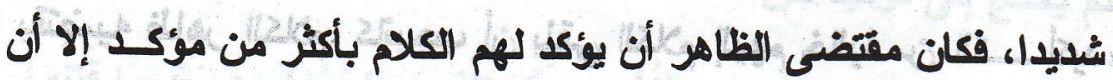
البعث لسا كاتت أبلته ظاهرة كان جديرا إلا ينكز، فنزل العخاطب منزبس السائل المتردد حثا له على النظر فى أدلته.

قال الخطيب القزوينى: (1) "وأكد إثبات البعث تأكيدأ واحدا -وإن كسان

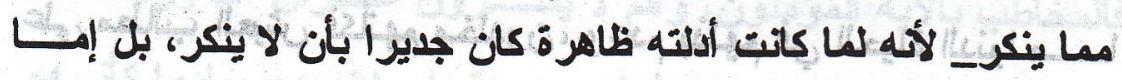
أن يعترف به أو يتريد فيله، فنزل المخاطبون منزئة المتردين تنبيـها

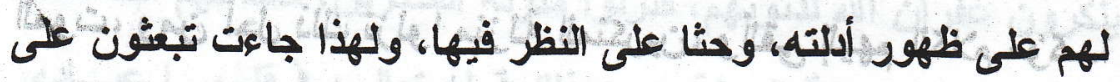

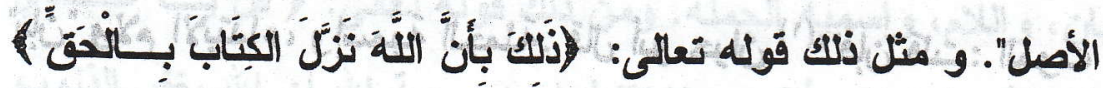

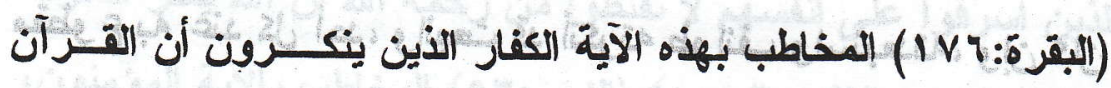

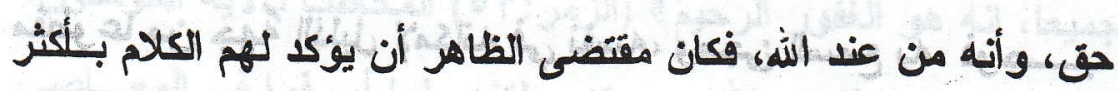

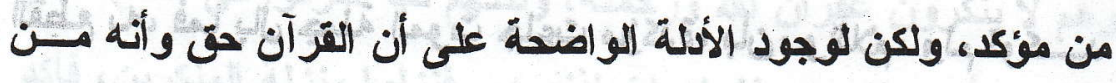

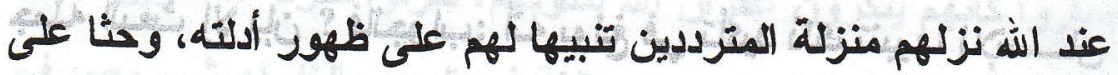
النظر فيها، والذي يقرأ القر آن بتأيلن يجد كثير امن هلهن الآيات. r-وقد ينزل غير المنكر منزلة المنكر إذا لاح على المخاطب شئ مـن

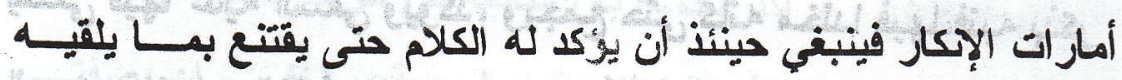

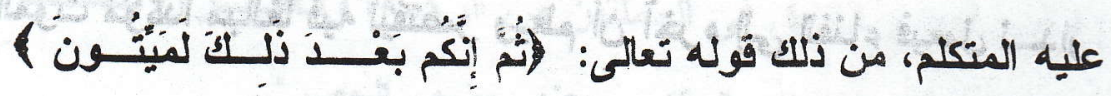




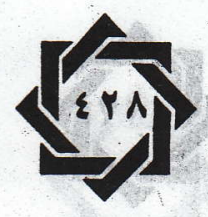

فالمخاطبون بهذه الآية الكريمة لا ينكرن الموت، لأن الموت لا ينكوه

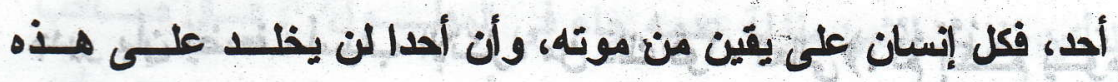

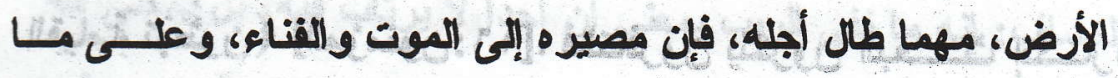
يقضيه ظاهر الكلام، كاتيجب أن يلقي الكلام إليهم خاليا من التــأكيد، ولكن الكلام قد خرج عن مقتضى الظاهر ، وألقى إلبــهم مؤكــا، فيـا السبب في ذلك؟.

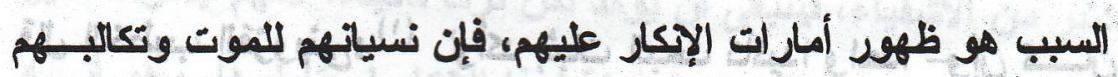

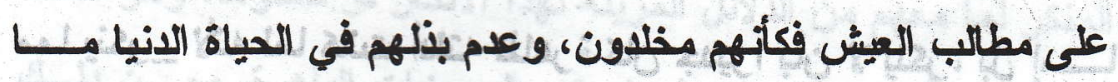

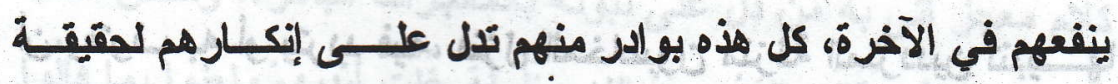
الموت، ومن أجل ذلتك نزلموا منزلة المنكرين، وألقى إيهم الكلام مؤكــا

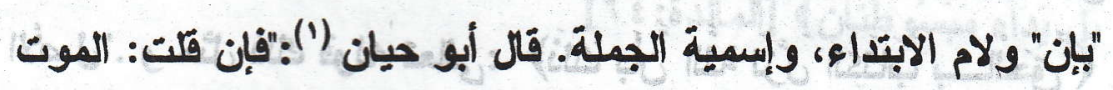
مضطوع به عند كل أحد، والبعت قد أنكرته طو أيف،واستبعته، وإن كان

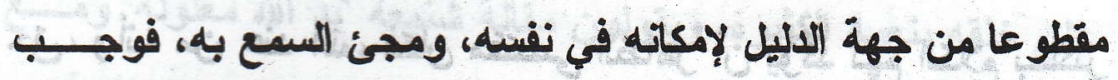

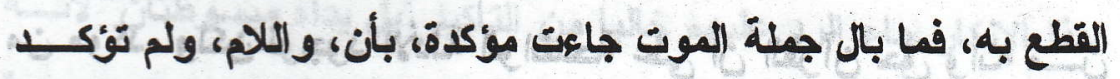
جملة البعث إلا بإن ؟ فالجواب: أنه بولغ في تأكيد ذلك تنبيها للإِسـان على أن يكون الموت نصب عينيه، ولا يغلل عن ترقبه، فإن مآله إليه، فكأنه أكد جملته ثلاث مرات لهذا المعن، لأن الإنسان في الصياة الانيـا يسعى فيها غاية السعي ويؤكد، ويجنع حتى كأنه مغلا| فيها،فتبه بذكر الموت مؤكدا مبالغا فيه ليتصر ويطم أن آخزه إلى الفناء فيعل لــار 


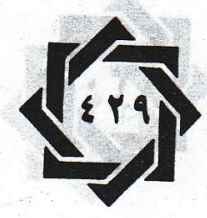

البقاء، ولم تؤكد جملة البعث إلا بإن ؛ لأهه أبرز في صورة المتطــوع به الذي لا يمكن فيه نزاع، ولا يقبل فيه إنكار وإته حتم لابد من كيانه، فلم بحتج إلى توكيل ثان".

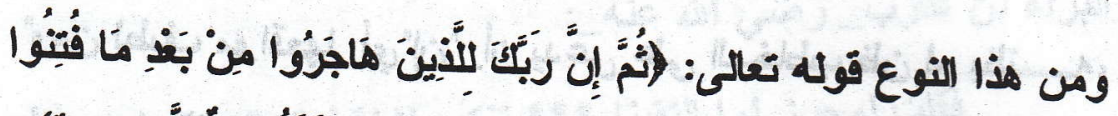

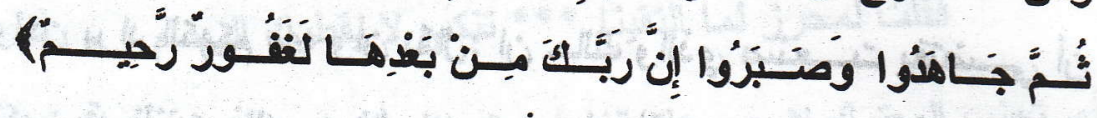

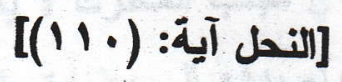

فالمخاطب بالآية المؤمنفن، وهم لا ينكــرون غنــران الله ورحتــه،

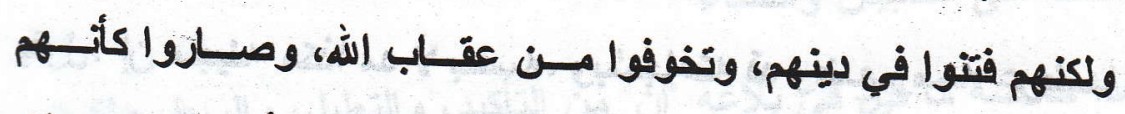

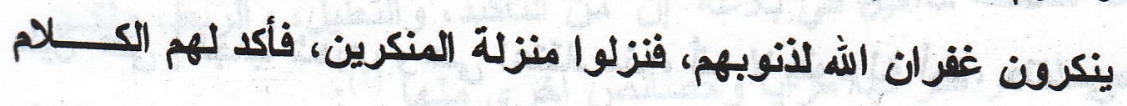
بإن، واللام، وإسمية الجملة. ومن ذلك قوله تعالى: ( قل يــانـ عبـادي

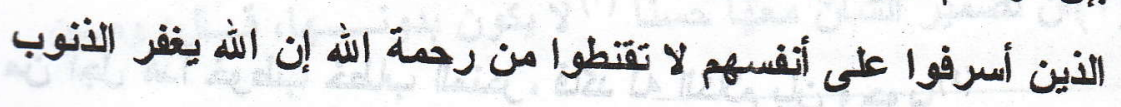

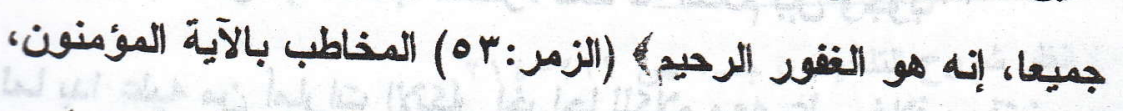

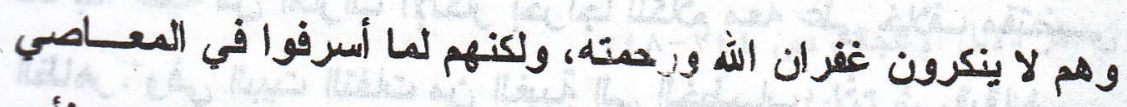
صاروا كأنهم ينكرون غفران الهه لذنوبهم، فنزلوا منزلة المنكرين، فأكد

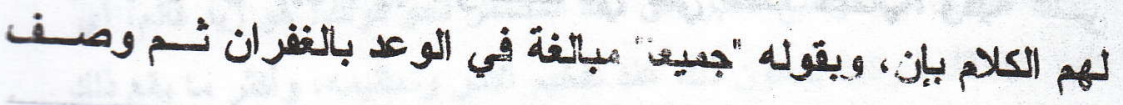

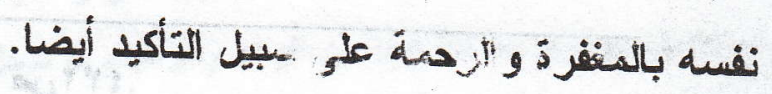

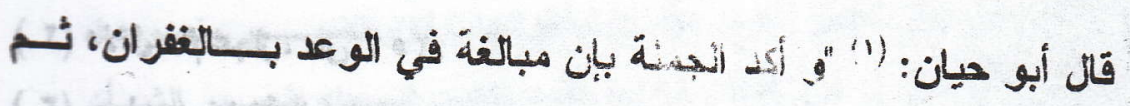

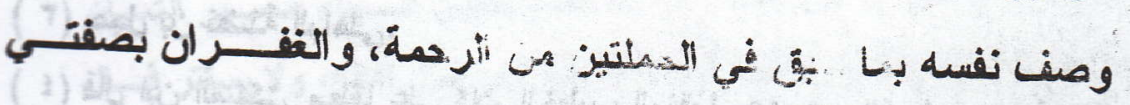
المبالغة، وأكد بلغظظ هو المقتديـ عند بهنهم الحصر". 
ويلخل في هذا النوح كثير من الآيات التي تخاطب الأببياء، والمؤمنين، ويأي الأسلوب مؤكدا.

قال عبد القاهر (v)

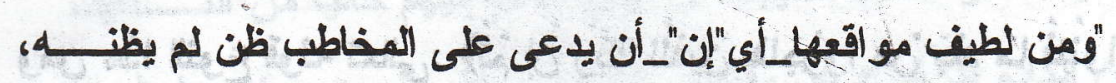

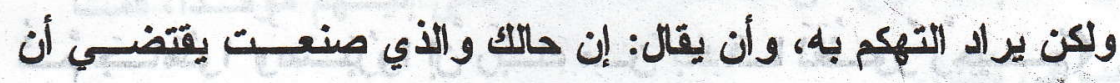
تكون قد ظنتت ذلك، ومثال ذلتك قول الأول (r):

جاء شقيق عارضا رمحه *"* إن بني عمك فيهم رماح

يقول: إن مجيئه هكذا هد لا بنفسه، وبشجاعته قد وضع رمحه عرضـا

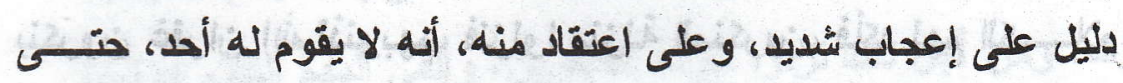
كأن ليس مع أحل رمع يدفعه به، وكأنا كلنا عزل".

من أجل هذا خوطب خطاب المنكر، فأكد له الكلام بإن وجوبا() لما بدا عليه من أمارات الإكار إخراجا للكلام معه على خلافت مقتضى

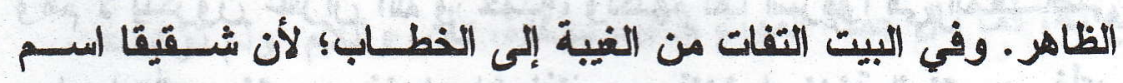
ظاهر ، وهو من قبيل الغيبة، والكاف في "بني عمك" خطاب، وفيه على لى لئ

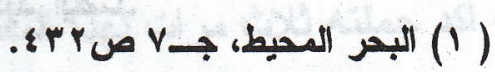

$$
\begin{aligned}
& \text { (r) دلاثل الإعجاز، ص rol (r) (r) }
\end{aligned}
$$

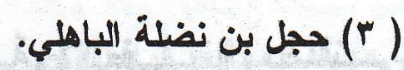

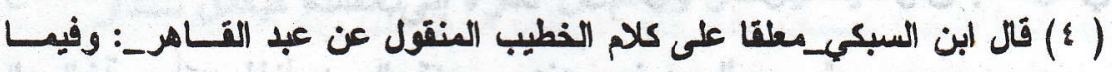

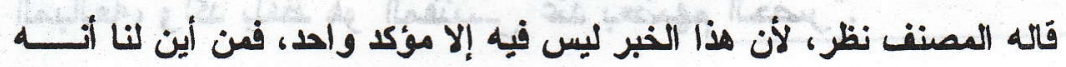

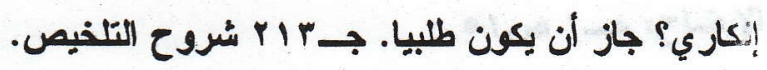




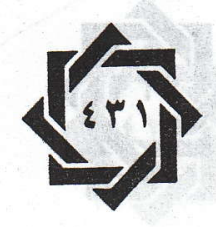

ما أثشار إليه عبد القاهر والمرزوفي.تهم واستهزاء كأنه يرميه بــأن

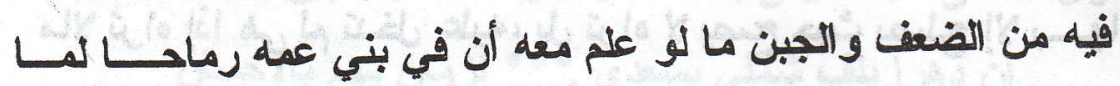

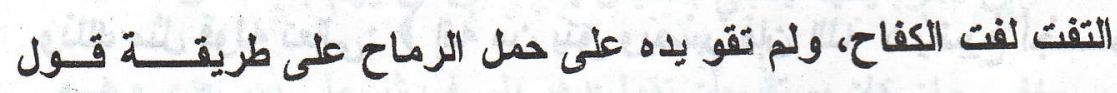

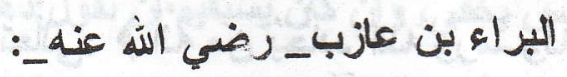
فتتا لمحرز لما التقينا *** تنكب لا يقطرك الزحام أي تجنب المعترك لا يصر عك الزحام، يرميه بأنه لم يباشر الثـــــــائد،

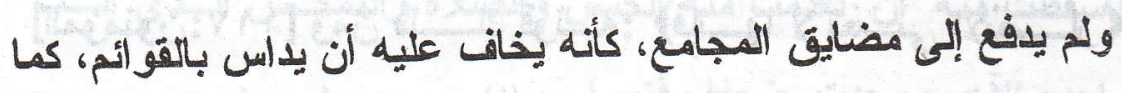

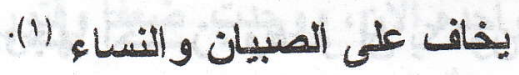
هذا خلاصة ما قيل في بلاغة "إن" هن التأكيد، والتعليل، و الربط، وركـن

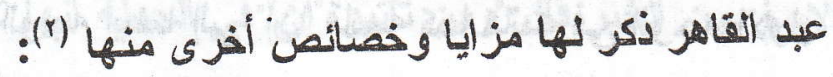

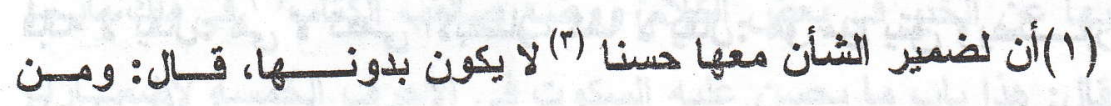

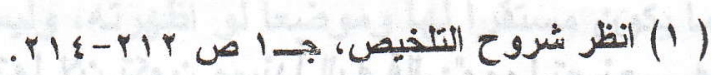

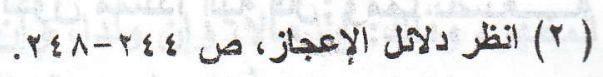

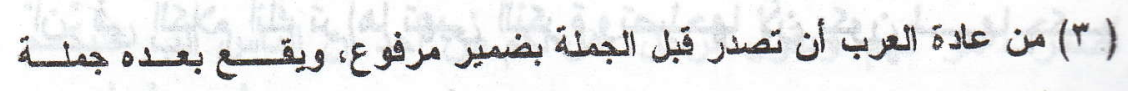

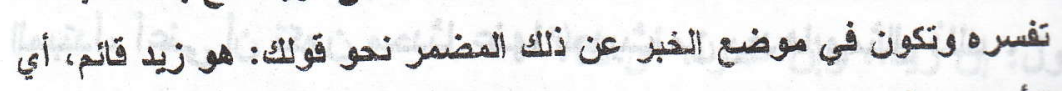

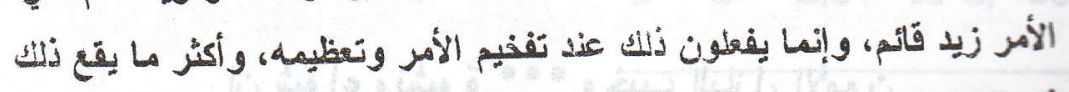

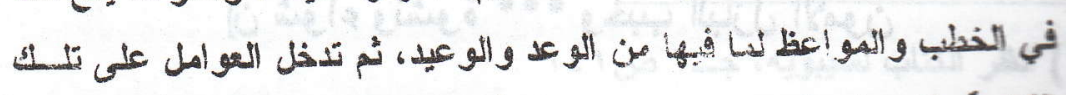

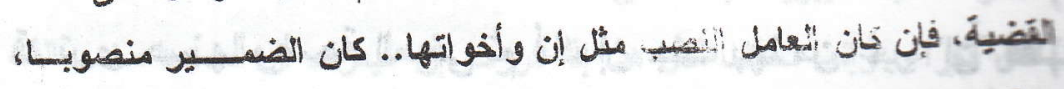

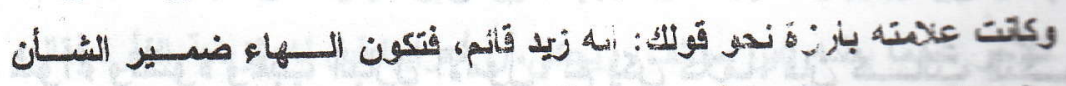

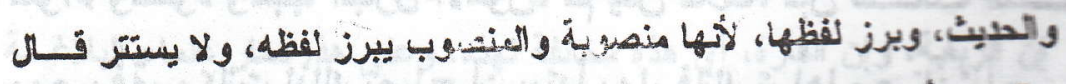

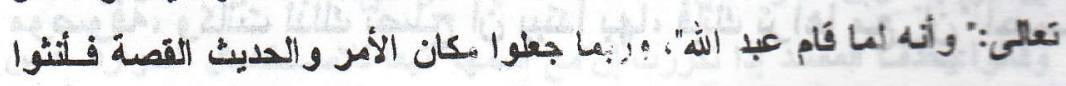

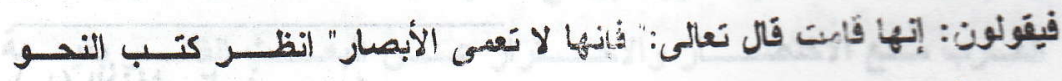
وبخاصة شر ح ابن يعيش، جـ V ص 1 ـ 1. 


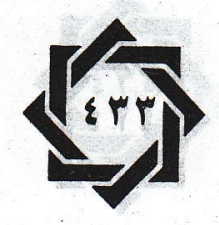

وترى المغى حينئ أولى بالصحة وأمكن، أقلا ترى إلى قوله: إن دهر ايلف شملى بسعى **: لزمان يهم بالإحسان

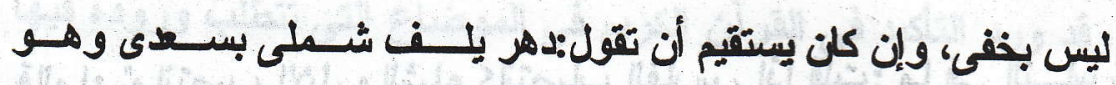
صلحجأن ليس الحالان على سواءهوكنلك بخفى أتك لو عدت إلى قوله:

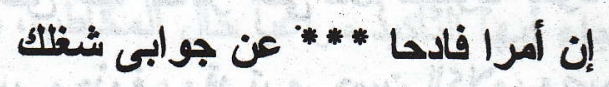

فأسقطت منه "إن" لعمت منه الحسن والصلاة والتمكــن الـــى أنــــ واجده الآن، ووجدت. ضعفا وفتورا.

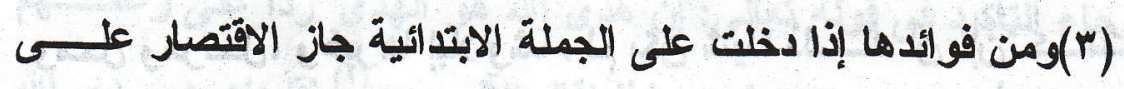

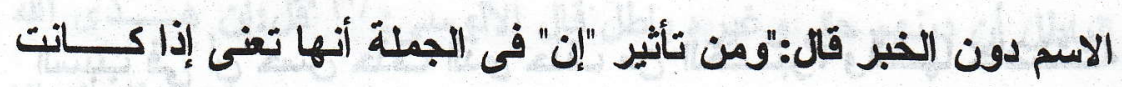

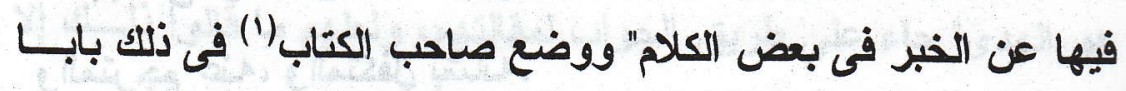

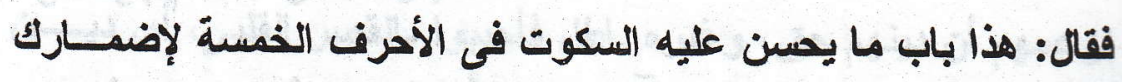

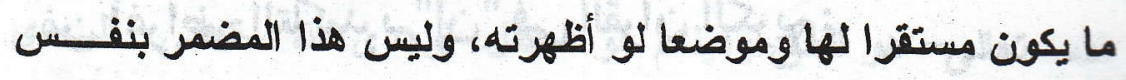

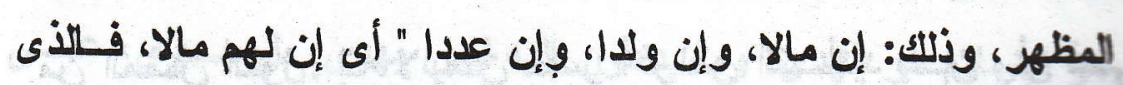

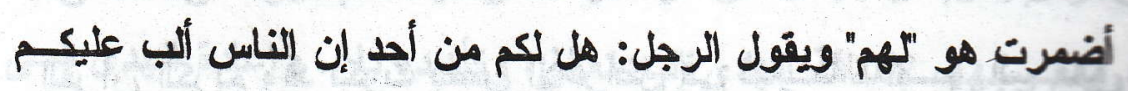

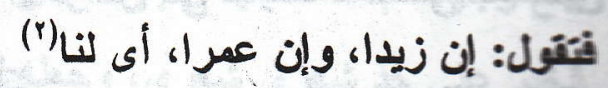

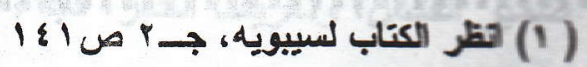

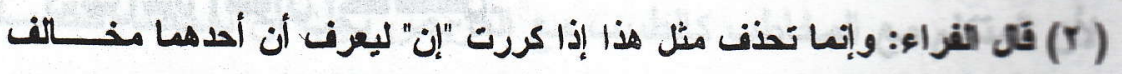

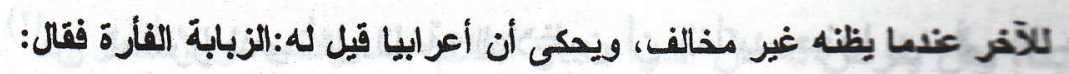

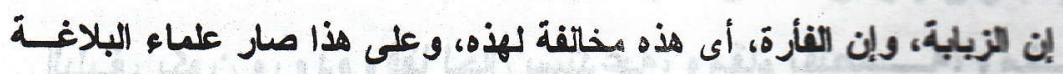

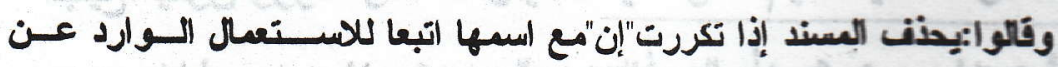

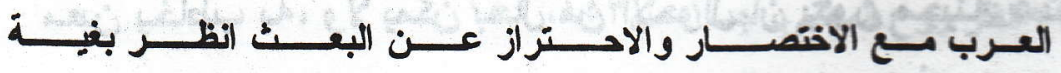

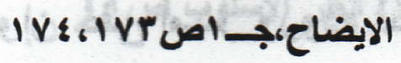




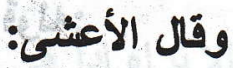

إن محلا وإن مرتحلا *** وإن فى السفر إذ مضوا مهلا

قالوا: "و انتصب الإبل و الثشاء كانتصاب الفارس إذا قلت: ما فى التـاس

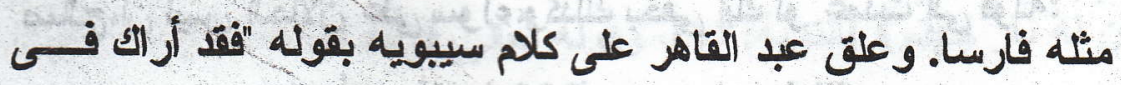

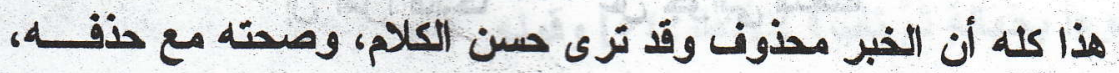

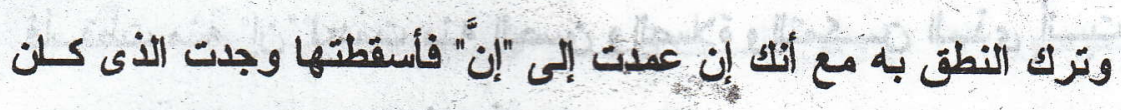

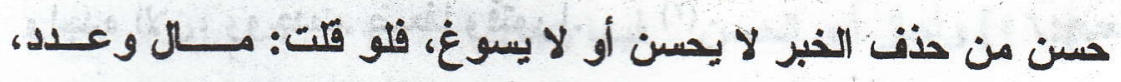

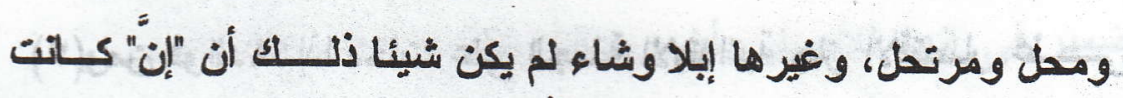

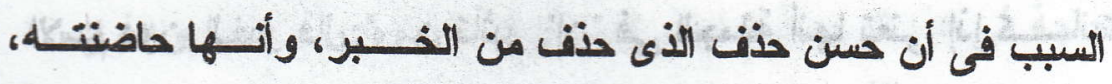
و المترجم عنه، و المتكلل بشأنه. من أغراض التأكيد بـ "إن" فى القرآن الكريم: من المكن القول: إنه لا يمكن حصر أغراض التـأكيد بـإن وأن فـى

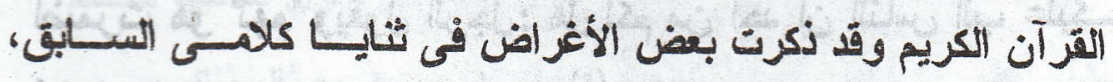
وأستطبع أن ألخص ذلك فيما يأتى:

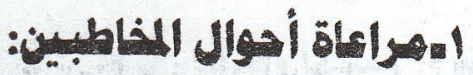

من المتقرر لدى أهل اللغة، البلاغيين أن التأكيد حينما يرد في العـلام

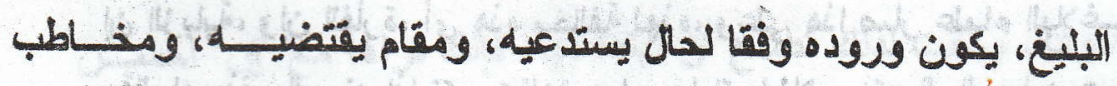
هعين بخاطب به، ولا يمكن بحال من الأحوال أن يكن مجيئه عبنًا فى لى الكلام،وزيادة يستفى عنها فى الجملة، وإن خفى أمبر وروده أحياتسا 


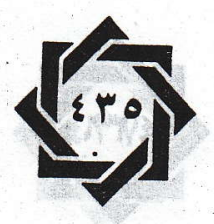

على من يتوقت بالكلمات عند ظاهرها، دون البحت عن المقام الأى جـايت بهاو السيأ الأى وربت فيه كما حلث للكندى مع أبى العباس المبرد. وقد ورد التأكيا فى القرآن الكريم فى الموضاع التى تتطلب وروده فيها فجاء على نهج فريد في مر اعاة الأحوال و المقامات، وقد ذكرت كثي فيرا

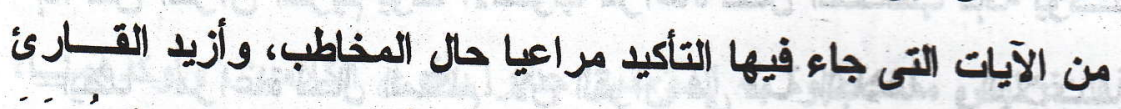

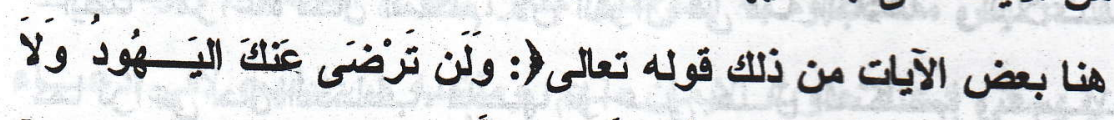

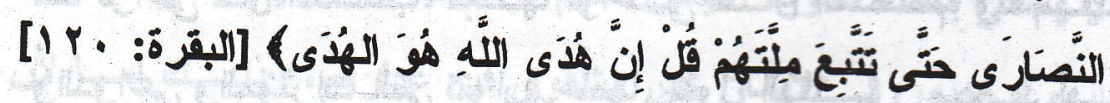

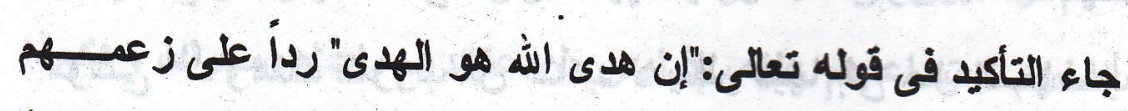

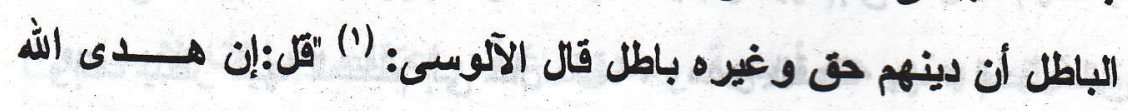

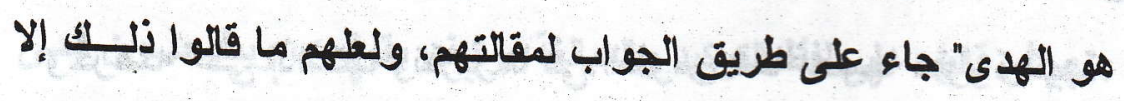

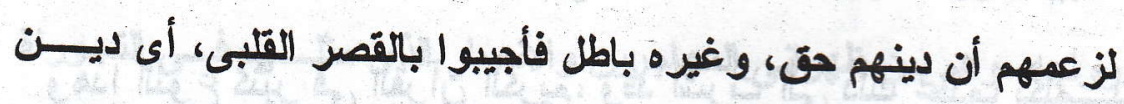

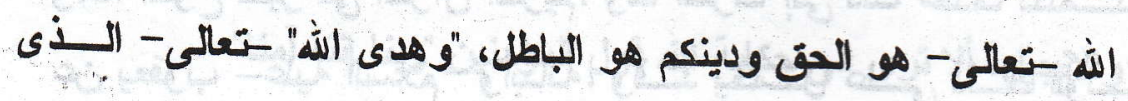

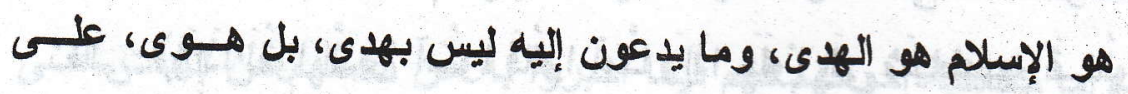

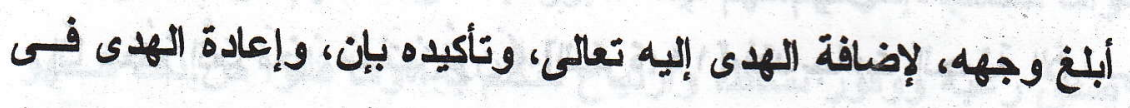

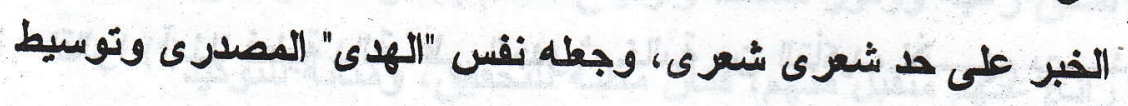

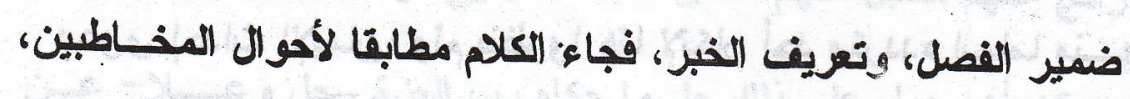
لأن المتكلم مع المخاطب كالطبيب مع المريض يجب أن يفصصه فحصـا دقيقا، وأن يفرض له من الاواء -أو الكلام- ما يلأممه و إلا أضر به(r)

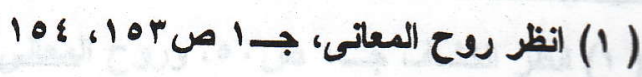

$$
\begin{aligned}
& \text { r) (r) (r) }
\end{aligned}
$$




\section{急}

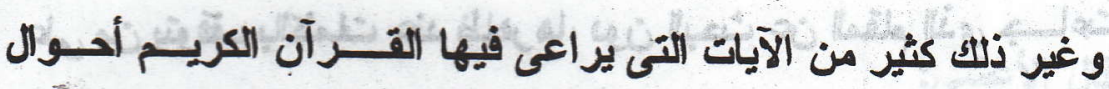
المخاطبين النفسية.

\section{:}

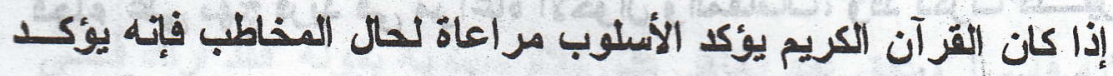

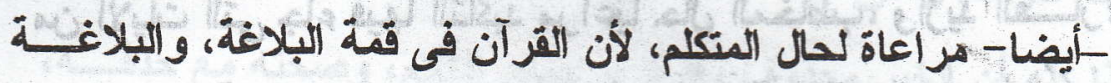

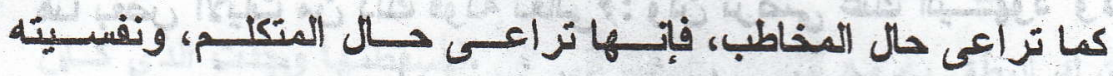

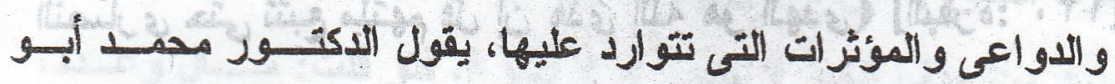

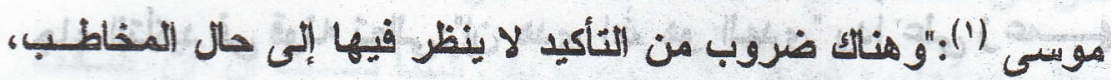

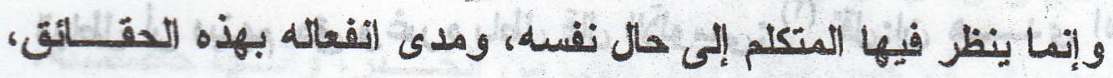
و هرصهل على إذاعتها وتقرير ها في النفوس كلا أحسها مقررة أكيدة.

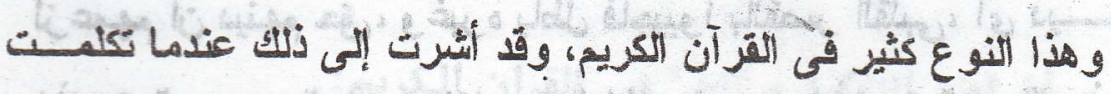

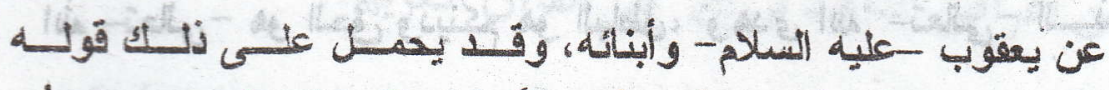

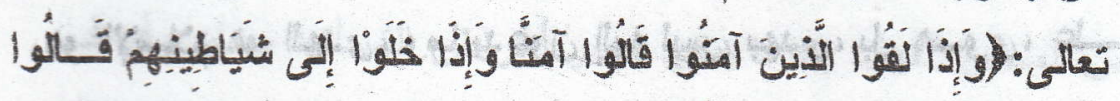

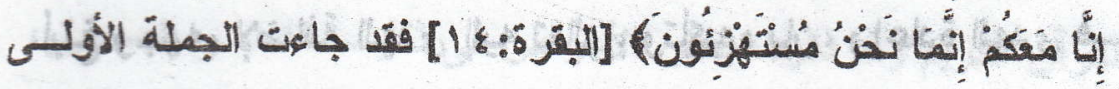

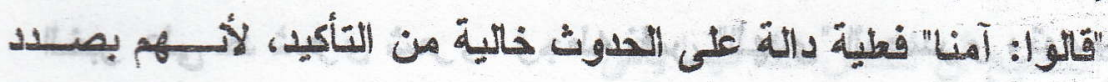

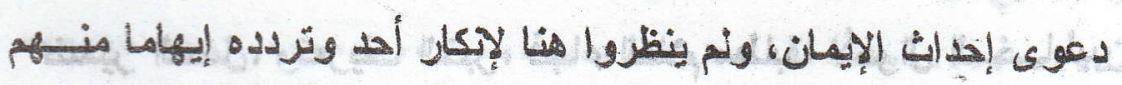
أنهم بهرتبة لا ينبفى أن يتردي في إيمانهم ليؤكدوا. وجاءت الجملة الثانية "إنا معكم" إسمبية ثبوتية مؤكدة بإن مراعاة لحال

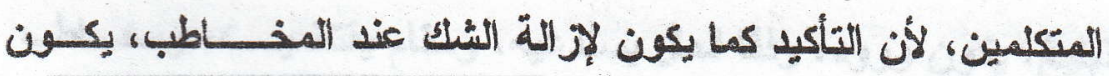




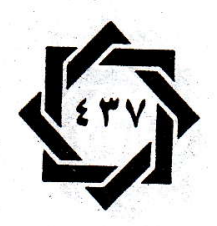

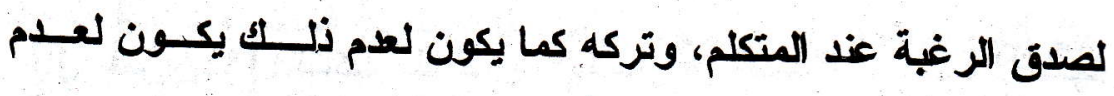
اعتناء المتكلم، فمن أجل الرغبة أكلوا، ولعمها تركواء

ولحظ ذلك الزمخشرى فقال: فإن قلت: لم كاتت مخاطبتـــم المؤمنيـن بألجملة الفعلية، وشياطينهم بالاسمبة محققة بإن ؟

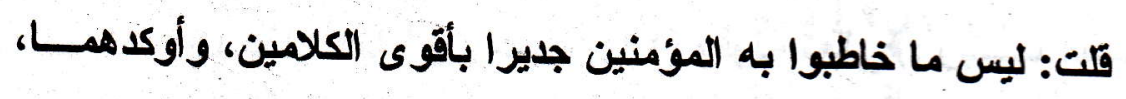
لأههم فى إدعاء حدوث الايمان منهم، ومنشئه من قبلهم، لافى ادعـــاء

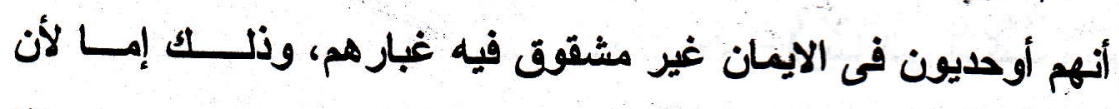

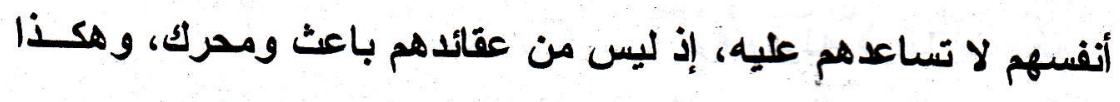

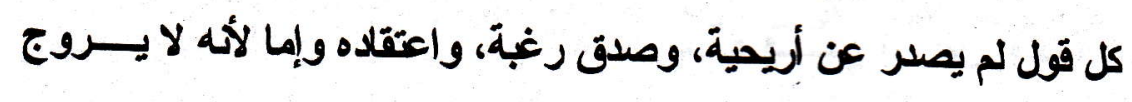

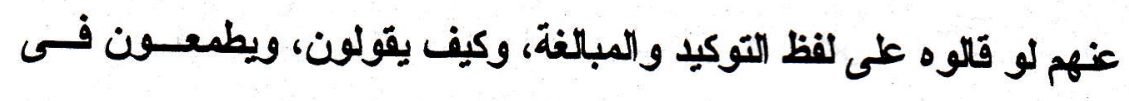

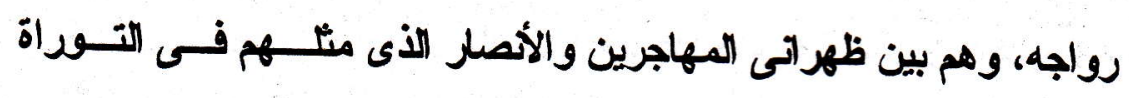
والاجيل، ألا ترى إلى حكلية الهه قول المؤمنين "رينا إنتا آمنا" وأما مخاطبة إخواتهم فهم فيما أخبربا به عن أنفسهم من الثبات عبى أنى

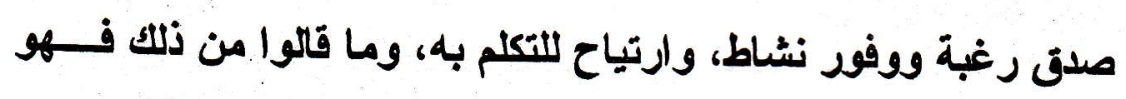

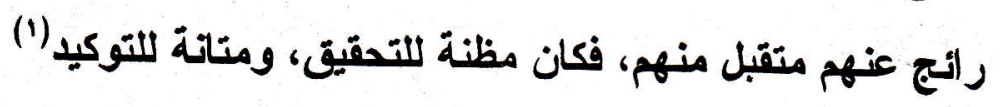
ويمكن أن بحمل على ذلك جل ما حكاه رب العزة -جل وعـــلا- عـن النبياء والمؤمنين متضر عين راجين داعين خالقهم كقوله تعالى (: ربَّنَا

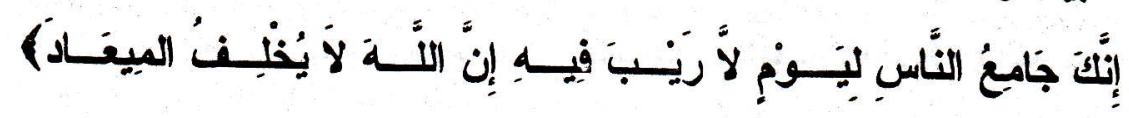

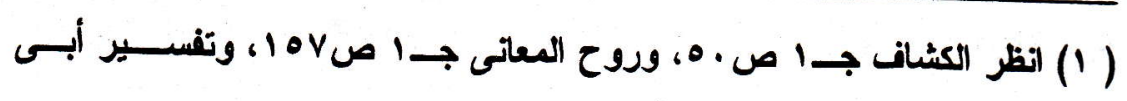

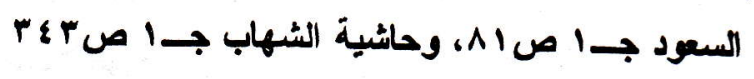




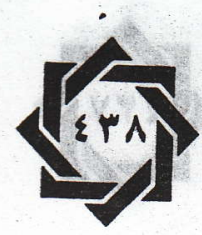

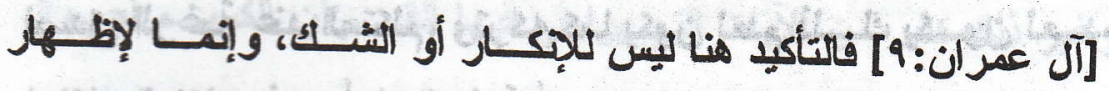
رغبتهم فى الاستجابة قال الآلوسىى (1):و التأكبي لإظهار ما هم عليه مـن

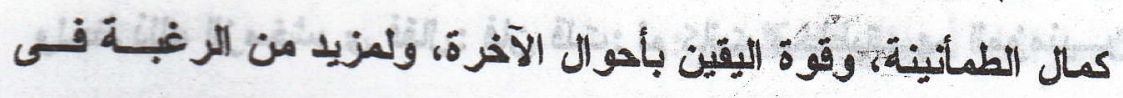

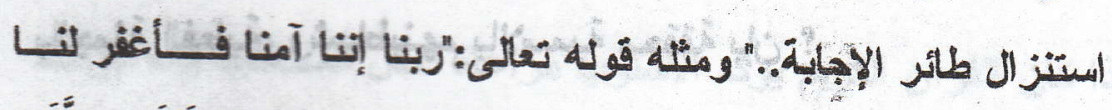

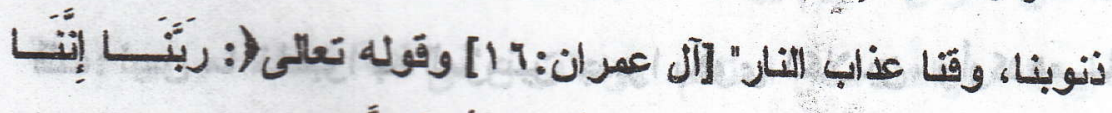

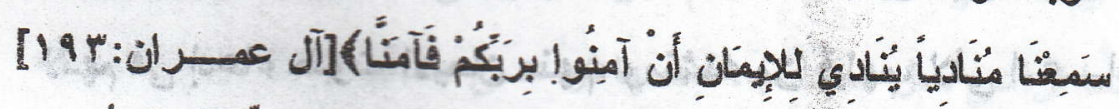

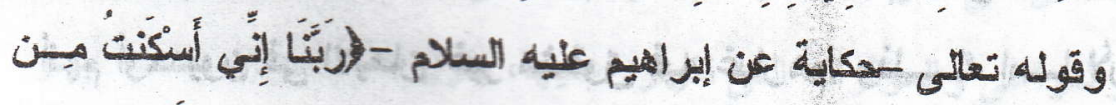

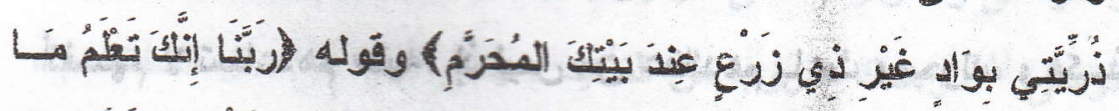

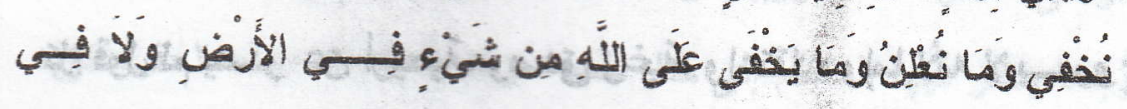

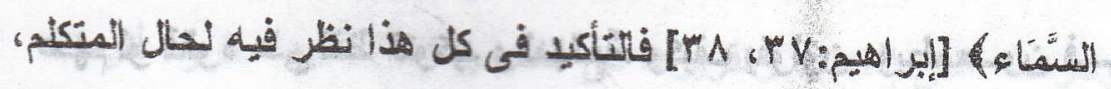

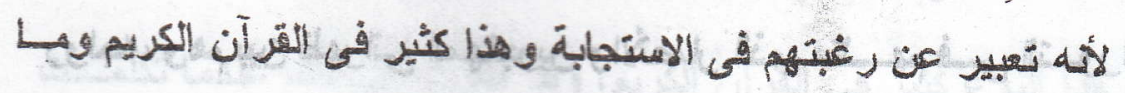
ذكرته فيه (أكفاية)

\section{:}

وقد يكون الغزض من التأكيد قصل تحقيق المخبر به، وتقوية مضمسون

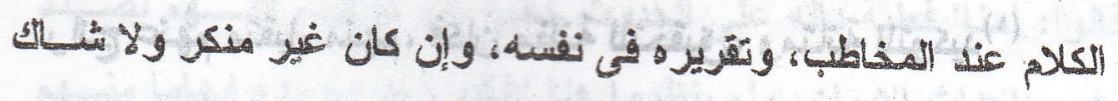

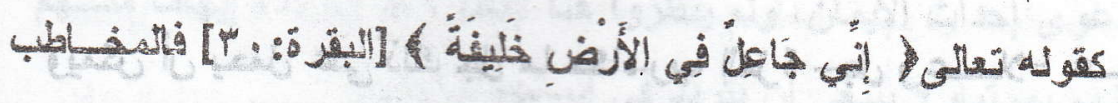

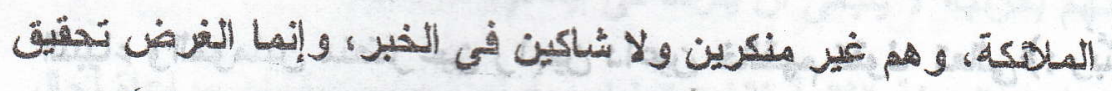

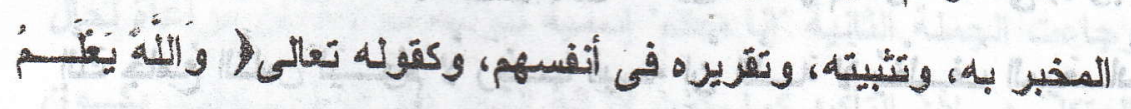

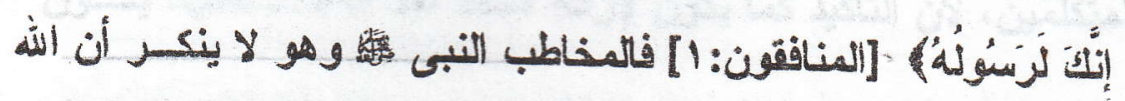




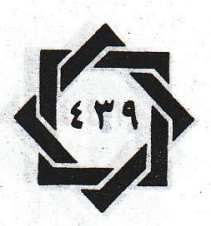

يطم أنه رسوله، ولا هو بموضع من ينزل منزلة المنكر وإنمــا جـاء

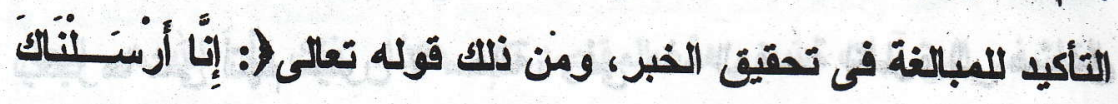

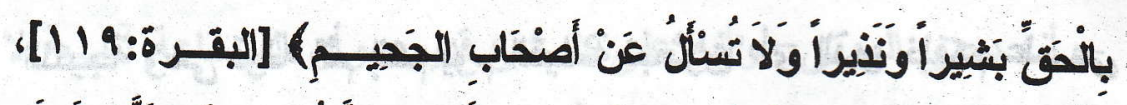

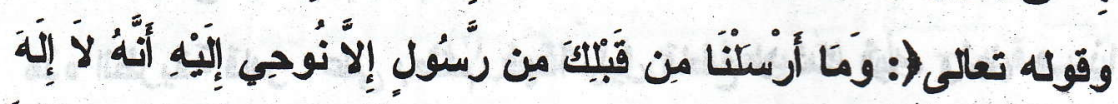

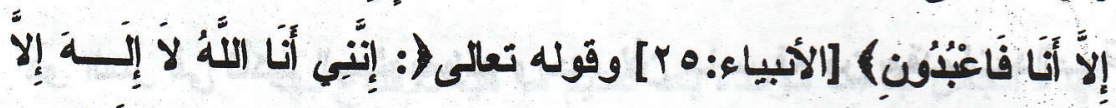

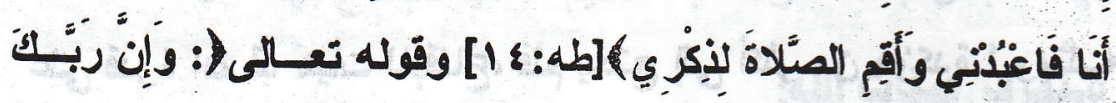

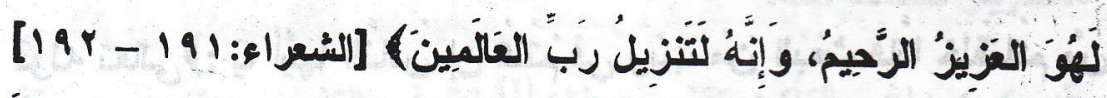

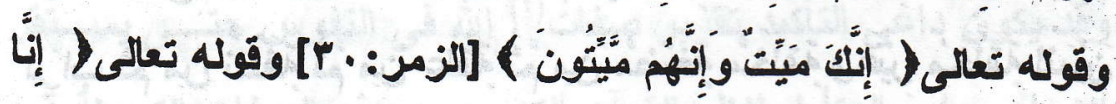

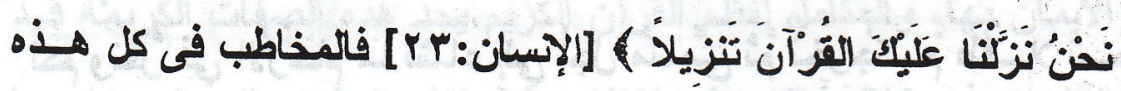

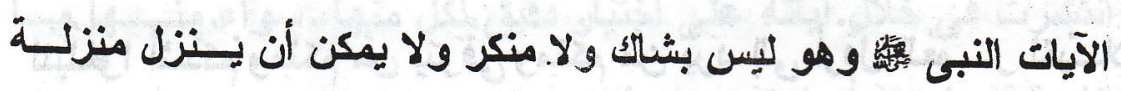

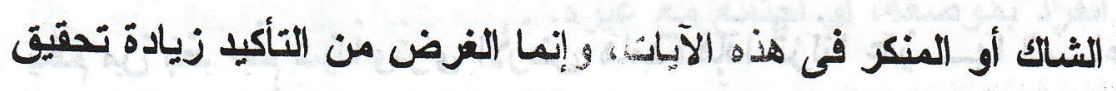

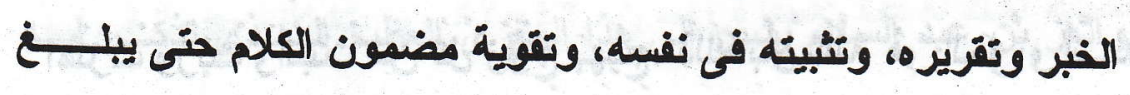
عين اليقين.

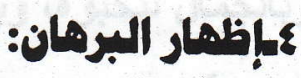

وقد يكمن داعى التوكيد إظهار البرهان الساطع، والداليل القاطع عـى صدى القضية انظر إلى قوله تعالى (: ولقد خلقنا الإسان مـن سـلالة

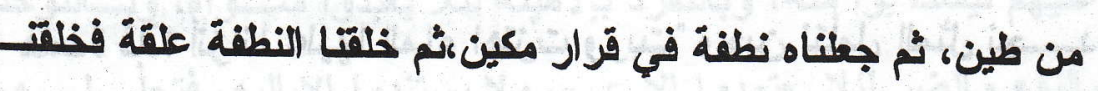

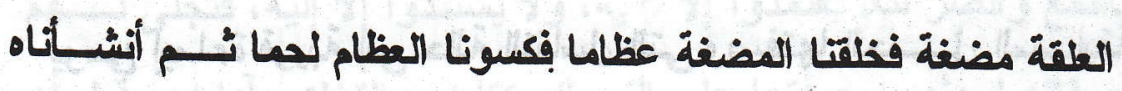
خلقا آخر فتبارك الله أحسن الخالقين، ثُم إنكم بع ذلاك لميتون، ثُم إنكم

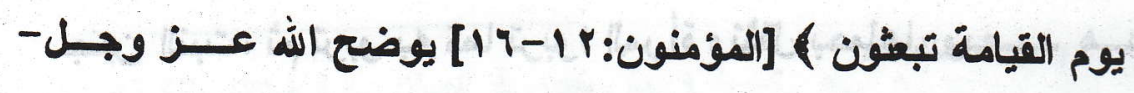




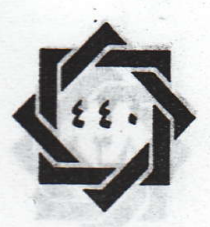

لعباده بعل بياته لظفهم على هذه الطريقة الدالة على التــدرة التـى لا

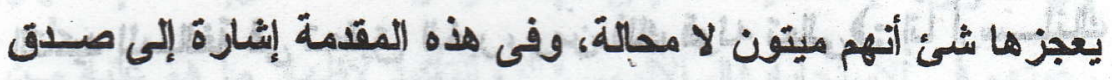

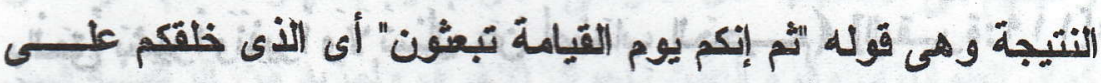

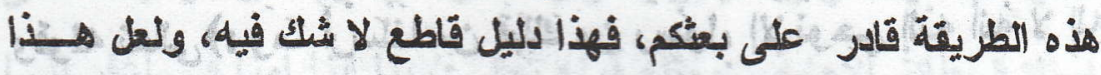
هو السر في تأكيد البعث بمؤكد واحد، لأن ما سبقه من مقدمات دالـــة

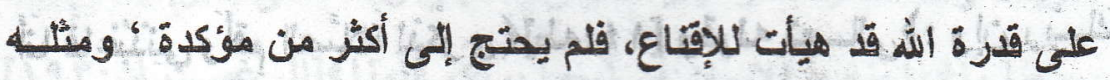

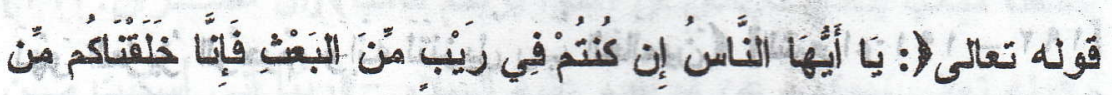

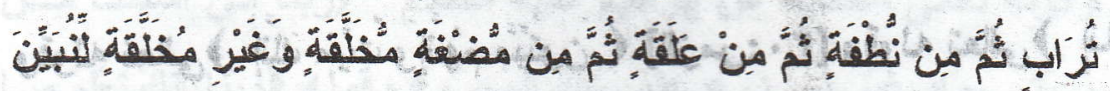

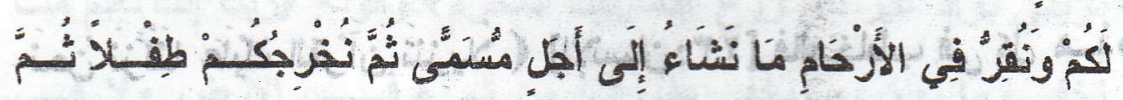

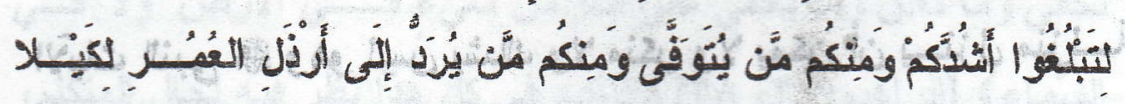

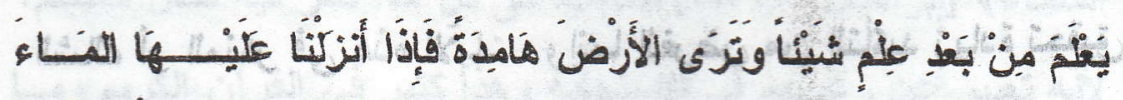

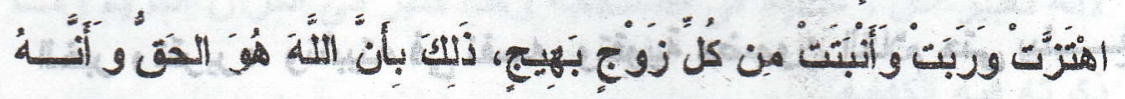

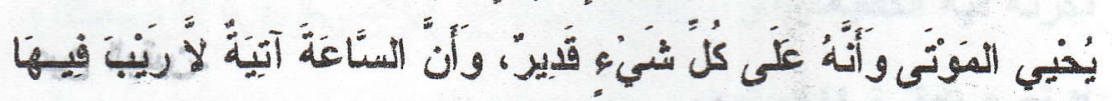

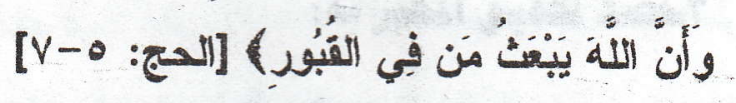

تجب الآيات الأولى تصف مر احل التكوين، وتبرز قدرة الله سبحانه مـن خلال هذا الوصف، ثم تقرب هذه الحقيقة بصورة حسية "وترى الأرض

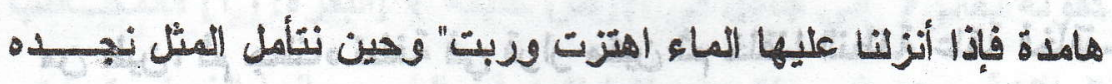
يومئ إيماءة قريبة إلى حالة التناسل التى وصفتها الجمبـلن الستيابقة،

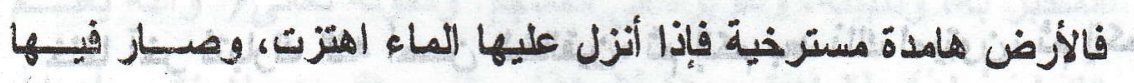

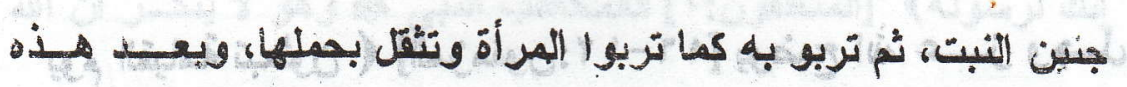




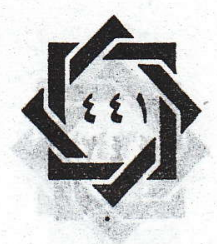

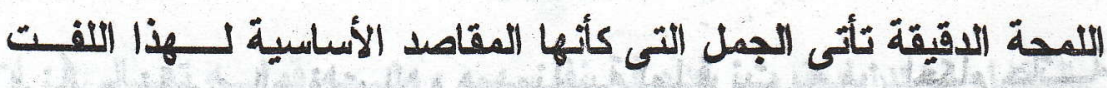
الكاشف إلى آيات الله و هذه المقاصد ترد هكذا، "ذلك بأن اله هو الحق

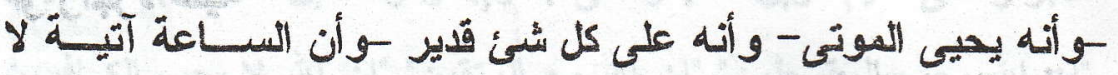
ريب فيها- وأن الله يبعث من في القبورئ فهذه الجمل جاعت مؤكدة بعد تفديم ما هيأ للإقناع بها

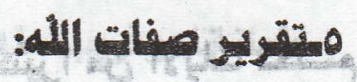

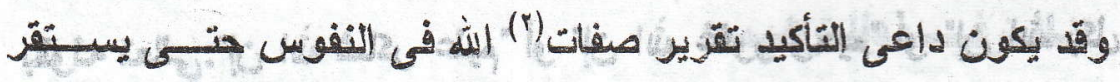

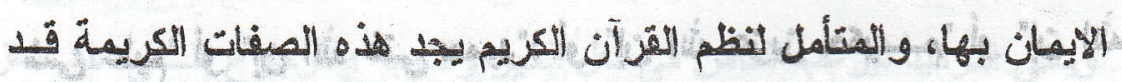

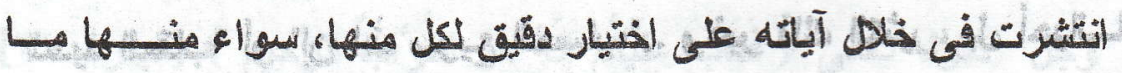

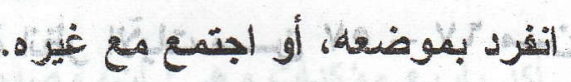

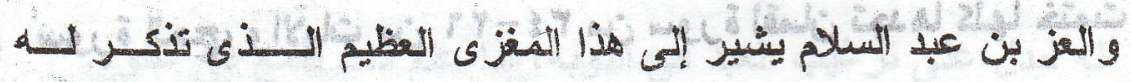

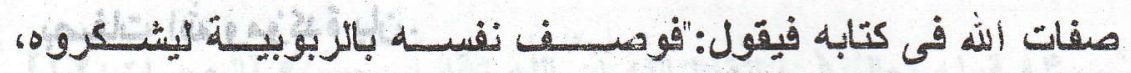

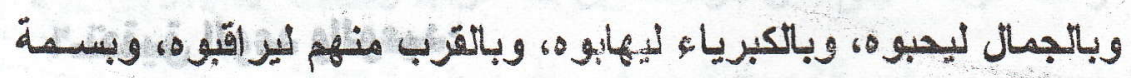

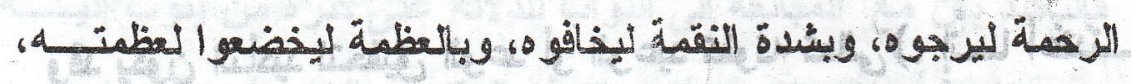

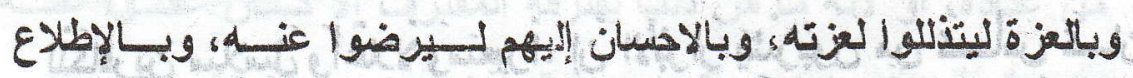

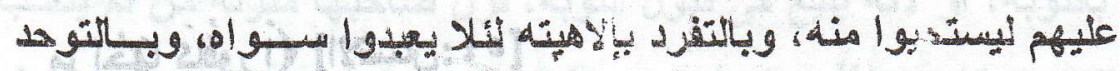

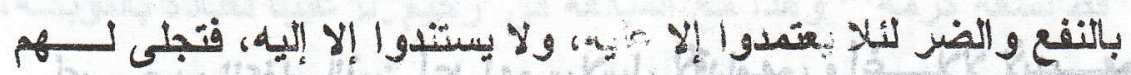

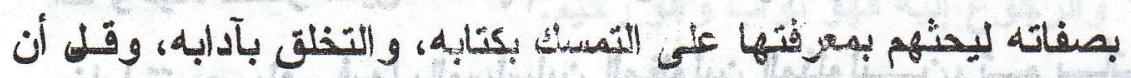

$$
\begin{aligned}
& \text { (1) وقيل أسماء اله }
\end{aligned}
$$

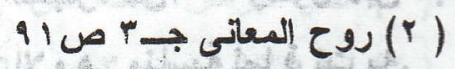




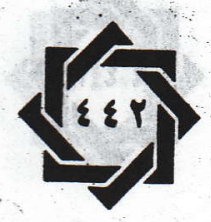

توبد صفة من الصفات إلا وهى مناسبة لما قرنت به من أحكام حاثــة

أ أو المرة عليه

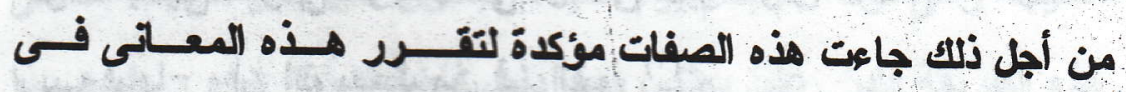

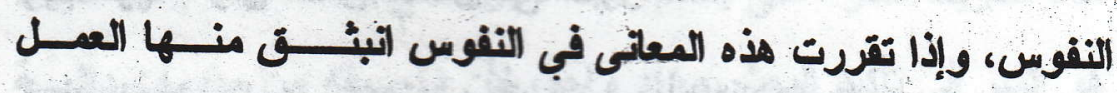

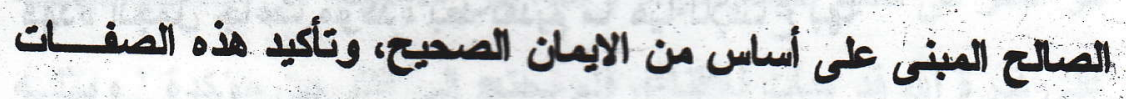

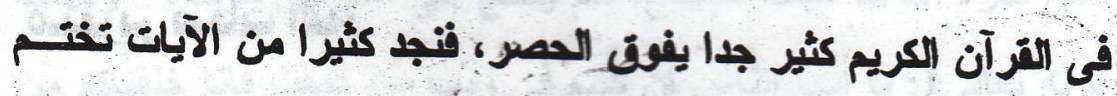
بقوبه تعلى:"إن الله شاكر عليم" أو "إن اله غنور رحيم" أو "إن اله بكل

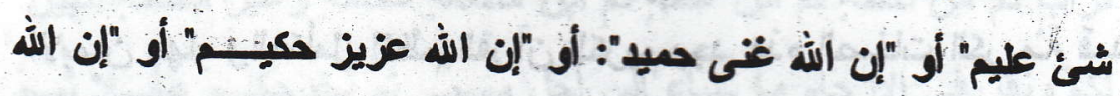
شديد العقاب" أو "إن اله سريع الحساب".. وغير ذلك الكشير، بل أحياتـا

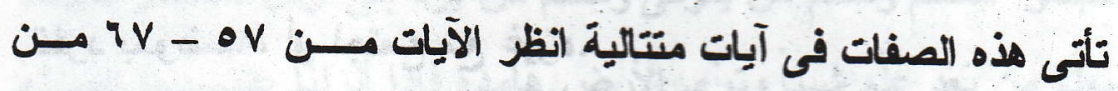

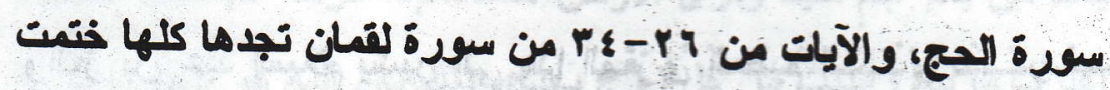
بصفات الله ومؤكدة بإن. 4.

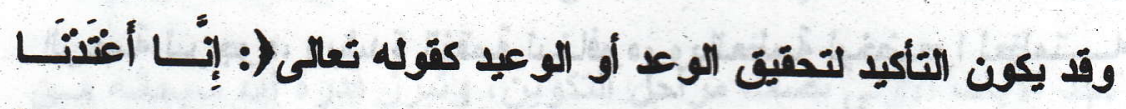

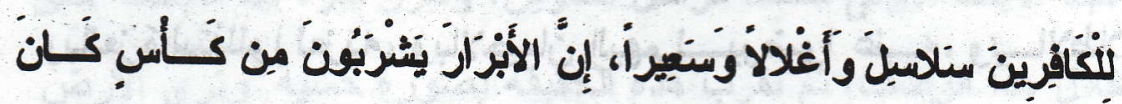

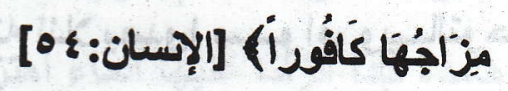

أكد و ويده للكفار الذين أعد لهم سلاسل لأتدامهم، وأغــلالا لأيديـــم،

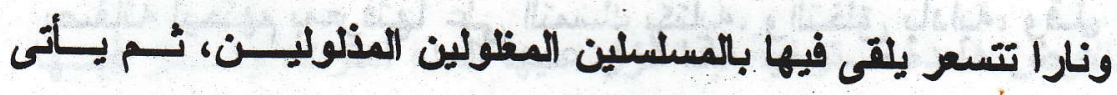

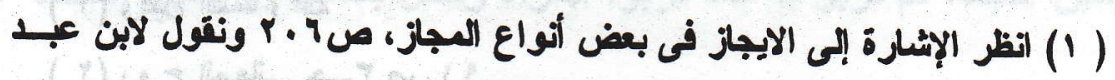
السلام يستحيل أن توجد صفة من الصبات إلا وهى مناسبة لها قرنت به. 


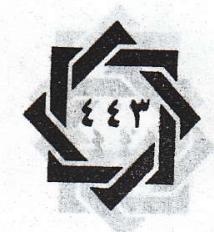

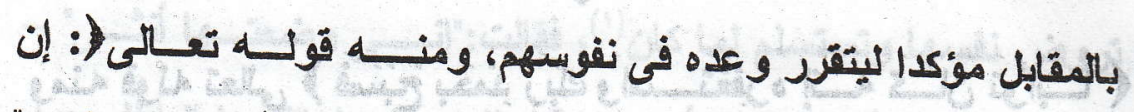
الأبرار لفى نعيم، وإن الفجار لفى جحيم) وقوله :"إن الله يحب المتقينت"

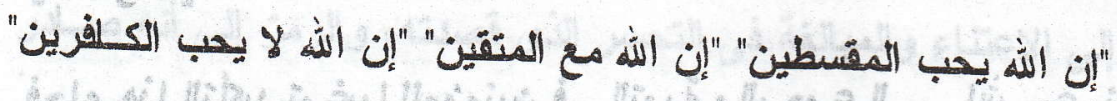

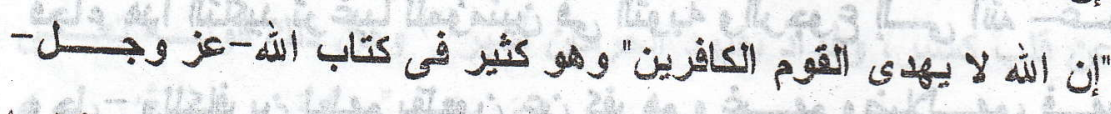

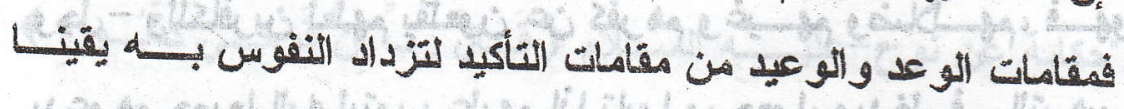
والطمينانا. وقريب منه:

\section{:}

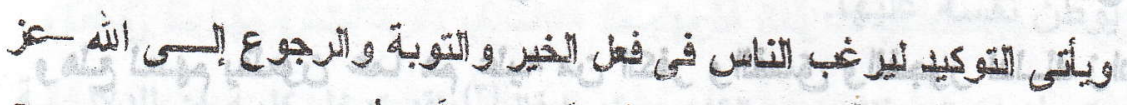

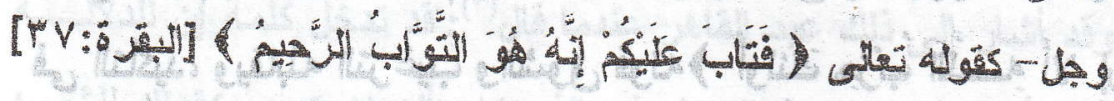

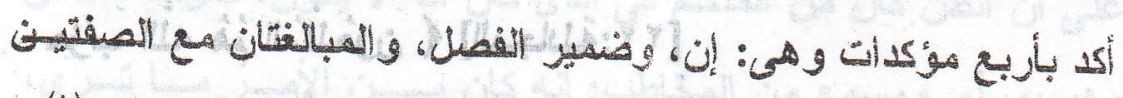

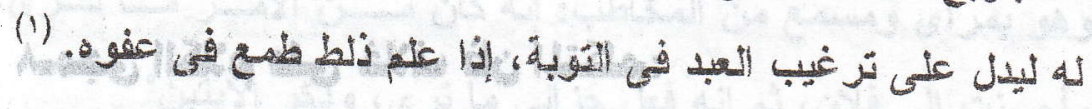

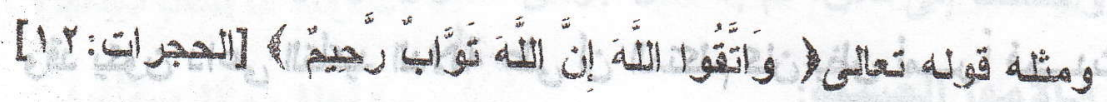

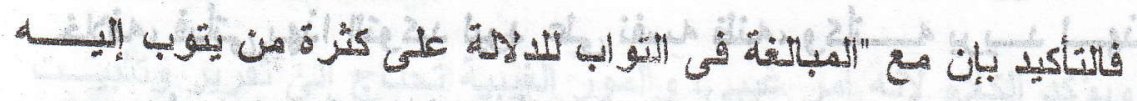

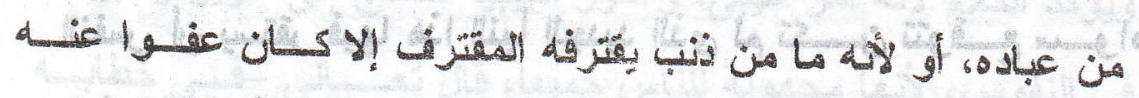

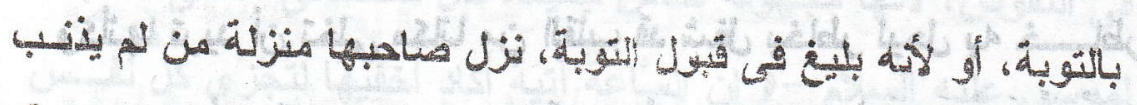

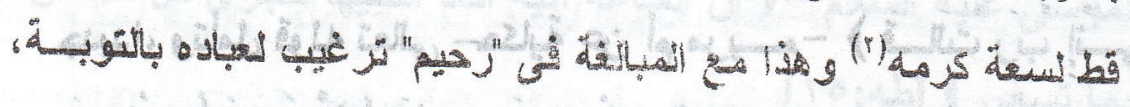

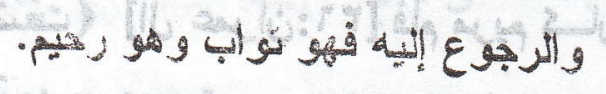

(انظر البرهان، ج (1)

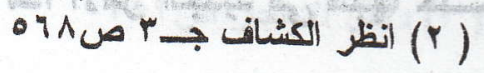




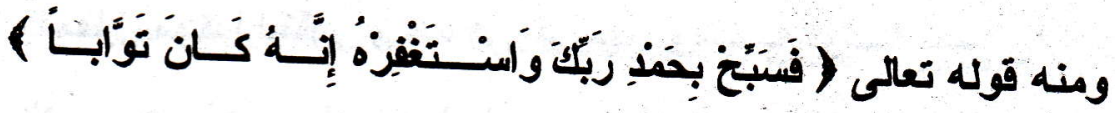

[ [ [ [النصر ]

فجاء هذا التأكيد ترغيبا للمؤمنين فى التوبة والرجوع إلـى اله ـعـز

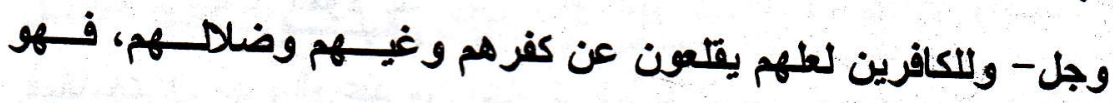

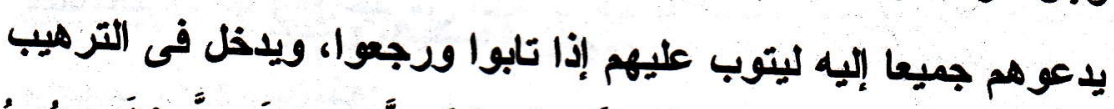

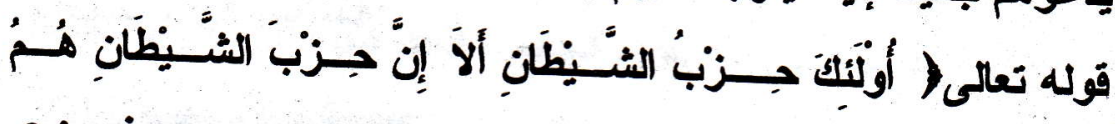

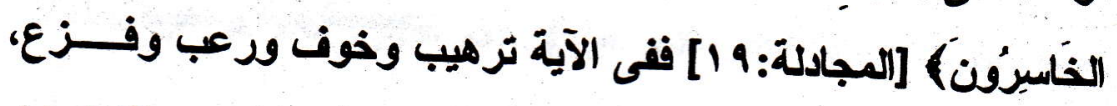

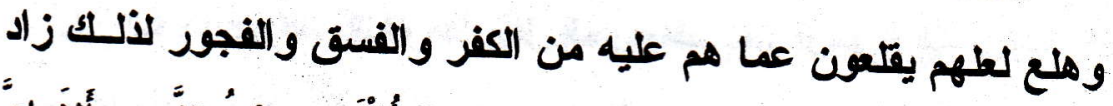

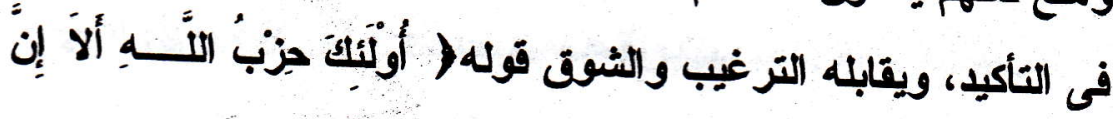

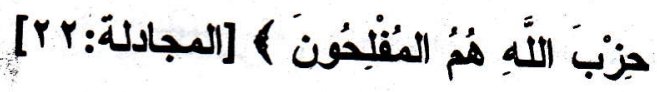

$$
\begin{aligned}
& \text { Ampبs الكلام على خلاف ظن المتكم: }
\end{aligned}
$$

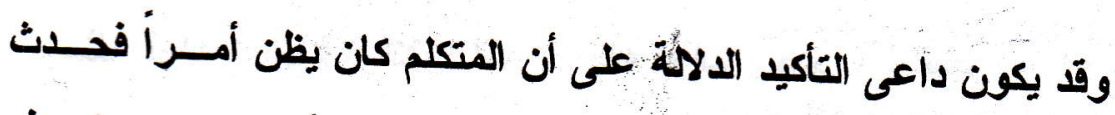

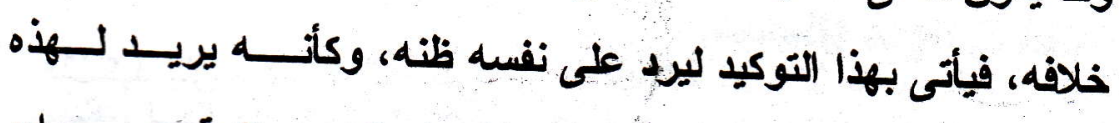

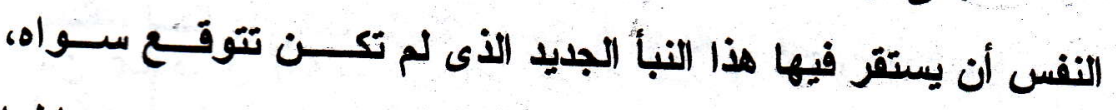

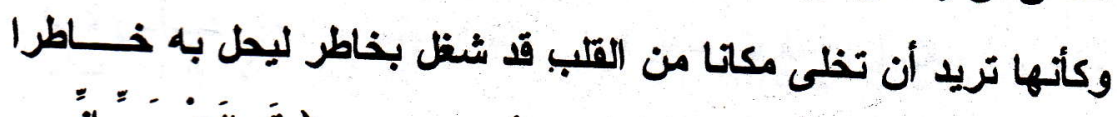

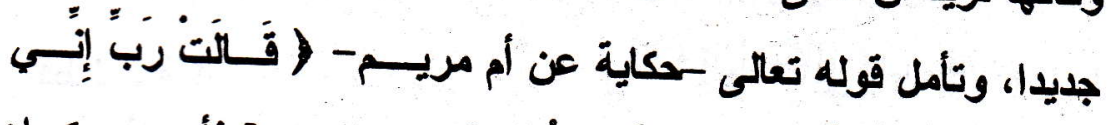

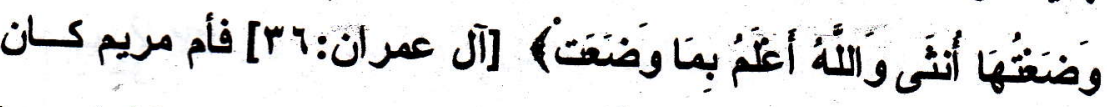

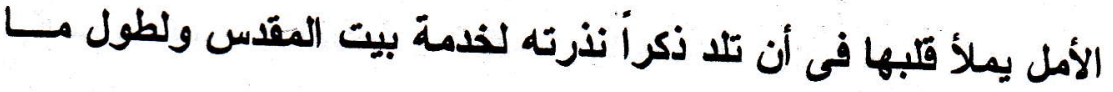

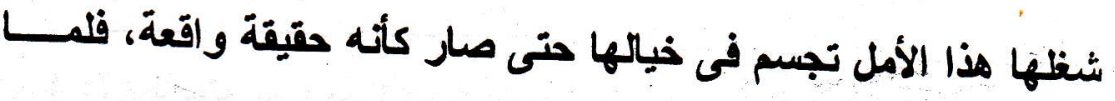

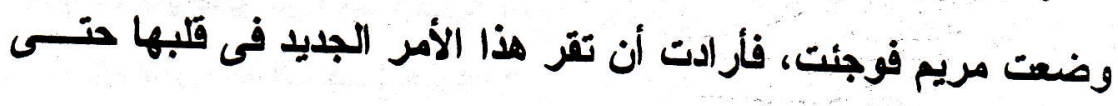




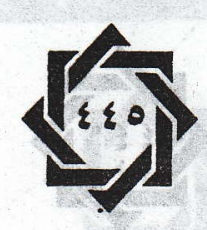

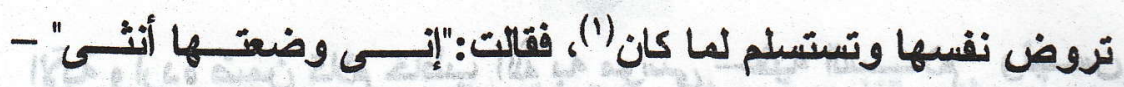
بالتأكيد - قال الألوسى:"و التأكبا هنا قيل:للرد على اعتقادها الباطل يعود إلى الاعتناء و المبالغة فى التحسر الأى قصدته، والرمز إلى أنه صـلار

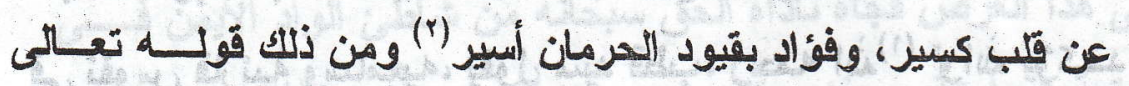

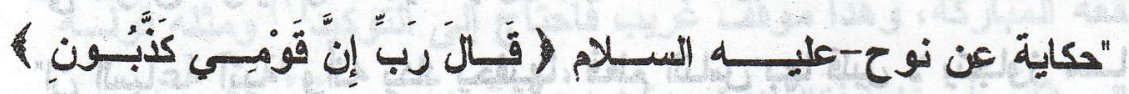

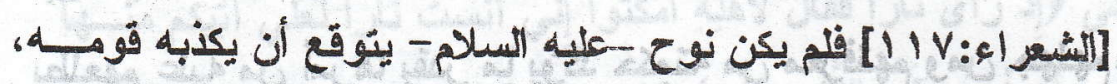

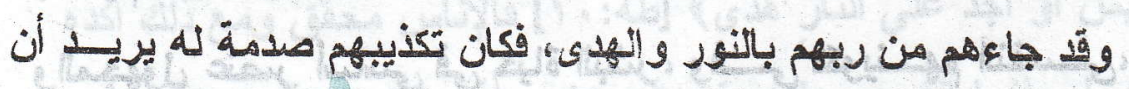
يوطن نفسه علبها.

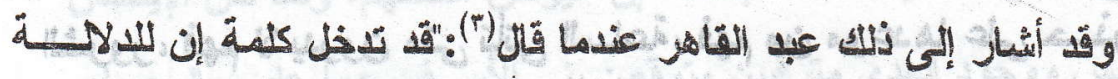
على أن الظن كان هن المنكلم في الذى كان أنه لا يكون، كقولتك للشتئئ

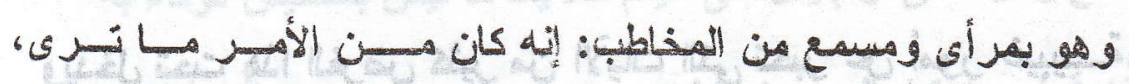
وأحسنت إلى فلان، ثم إنه فعل جزائى ما ترى، ونكر الآيتين"

: الأهم و

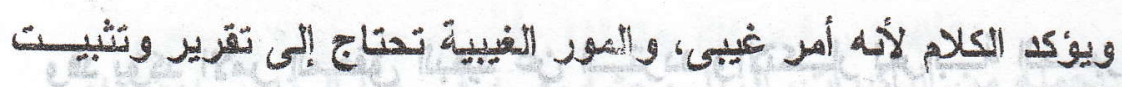

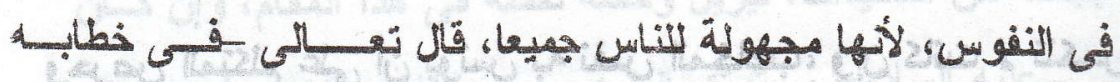

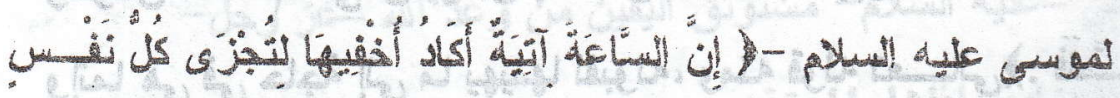

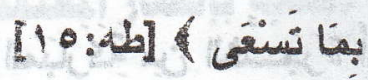

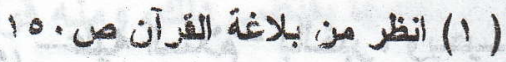

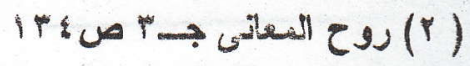

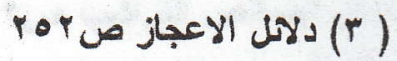




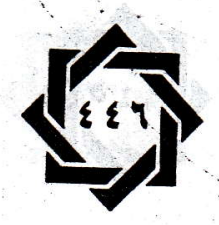

الآية واردة ضمن كلام خاطب الله به موسى ـعليه الســلام- وليسس

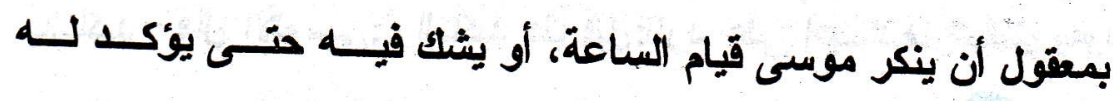

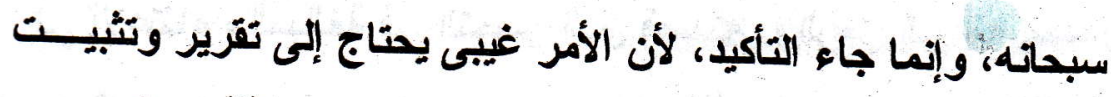

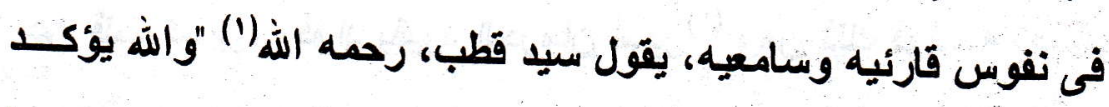

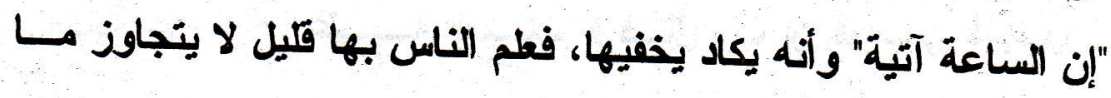

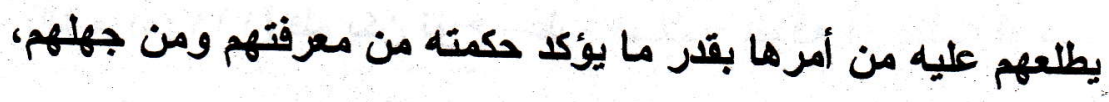

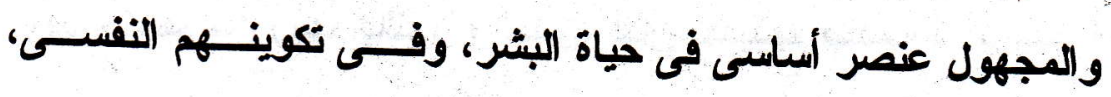

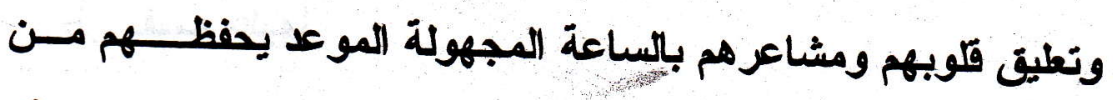

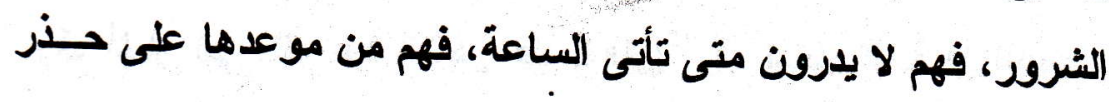

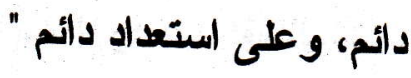
ويدخل تحت هذا الغرض كشير من الآيات التى تغبر عن أمور غيبيــة،

$$
\text { وجاعت بأسلوب التوكيل. }
$$

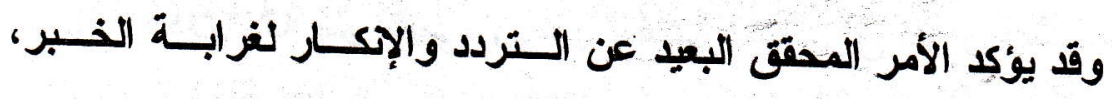
وحرص المتكلم على أن يؤنس به نفس المخاطب، وإن كاتت لا تنكــره

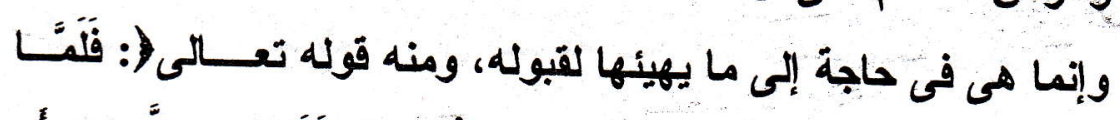

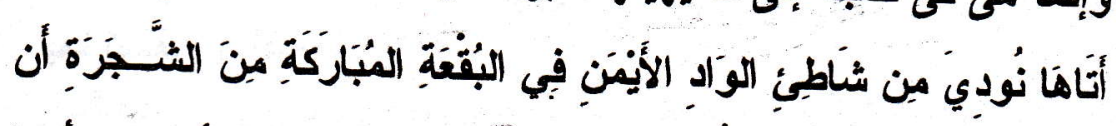

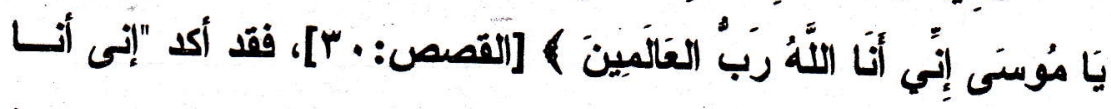

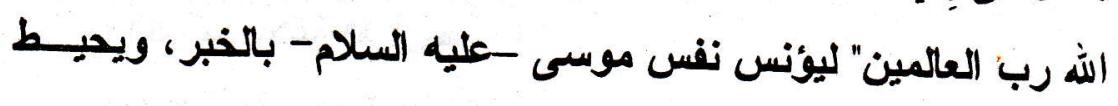




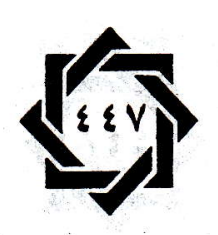

ما عساه يعلق بالنفس فى مئل هذا الموقف فقد انطلق -عليه السـلام-

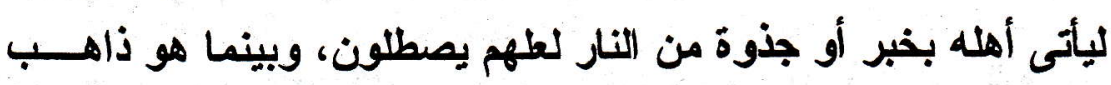

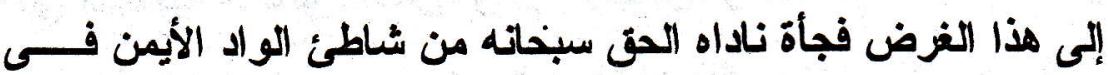

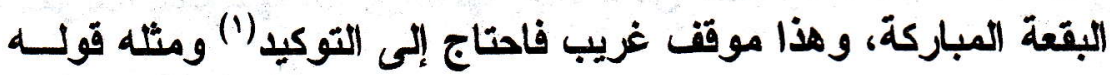

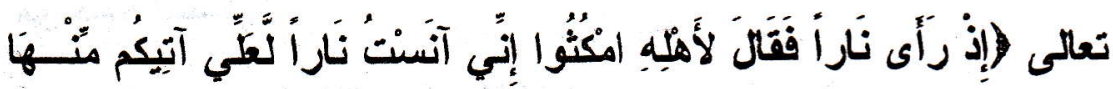

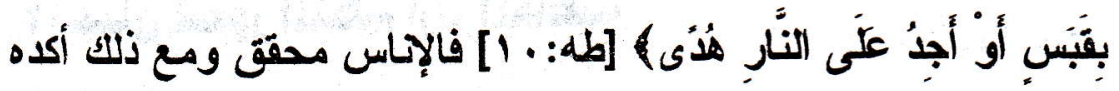
"إن" ليوطنوا أنفسهم عليه. قال الزمخشرى"(r) :"ولما وجد منه الإيناس فكان مقطوعاً متيقتا حققه بكلمة "إن" ليوطن أنفسهم، ولما كان الإيتــان بالقبس ووجود الهاى مترقبين متوقعين بنى الأمر فيـــهما عـى الرجــاء، والطمع وقال "لطى" ولم يقل :إتى آتيكم لئلا يط ما ليس بمستيقن الوفاء بهله

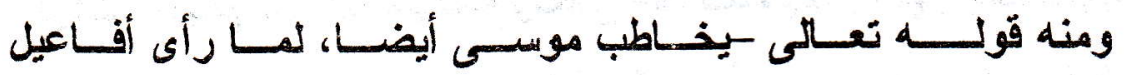

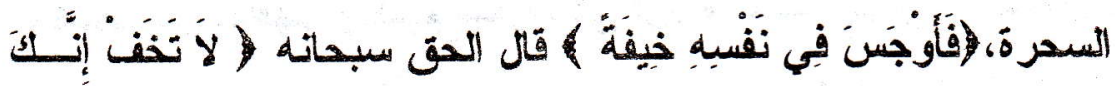

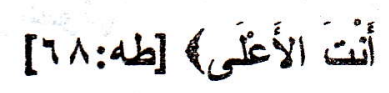

فأكلد بجملة من اللتأكيدات، نيزيل وحشة نفسهة فى هذا المقام، و إن كسان موسى -عليه السلام- مسنوثق اليقين من وعد الله - معز وجل-

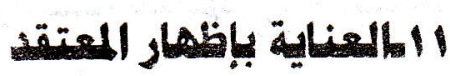

وقد يكون التوكيذ إظهارا لمعتثة النفس، وإبرازأ له لتزدلد النفس يقينـا

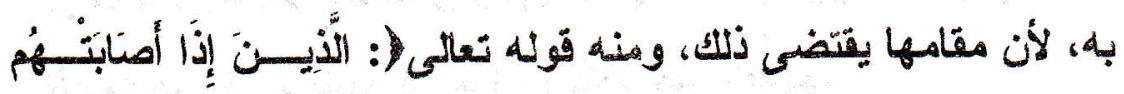

(1) انظر خصائص التراكيب صبان

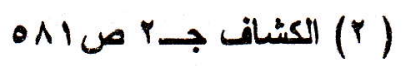




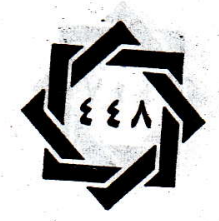

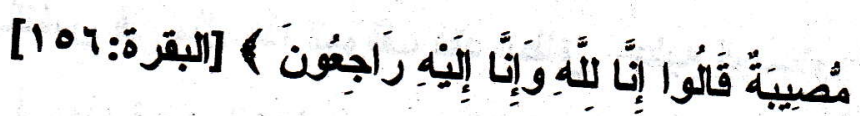

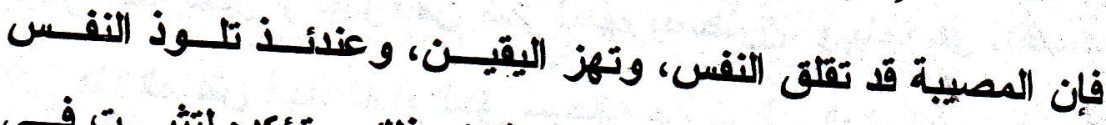

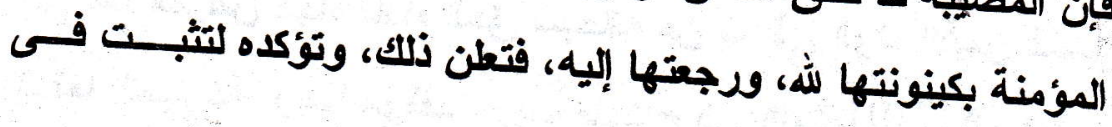

\section{مواجهة الشدة. \\ rابيان شعمد المتكم إزاء المخاطب هوه}

وقد يكون التأكيد لبيان شعور المتكلم من جهة أن المخاطب لا يطمئـن

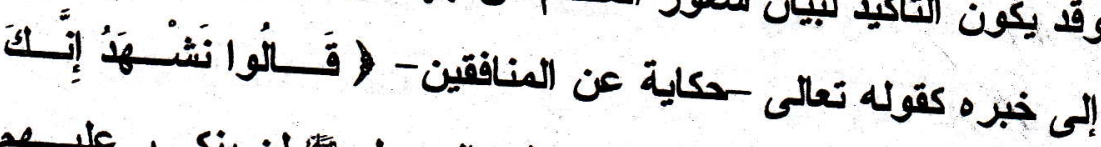

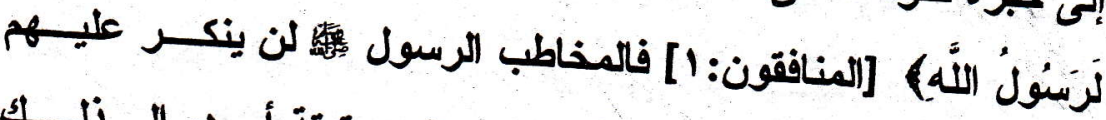

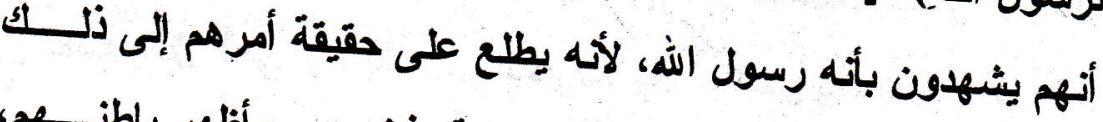

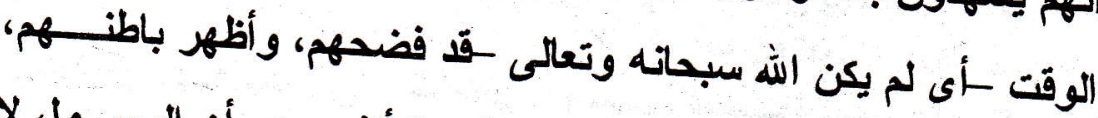

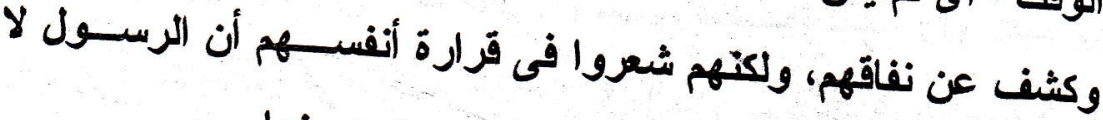
يستريح إلى إخبارهم، فأكدوا ليردوا دعوى يتو همونها. rا تنفبيه المخاطب على أن المتكميم كاذب فى دوماه: وقد يكون الغرض: تنبيه المخاطب على أن المتكلم كاذب فى إدعاء هذا

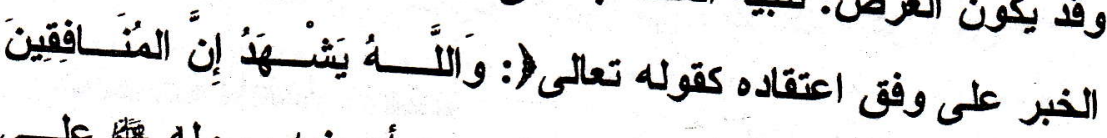

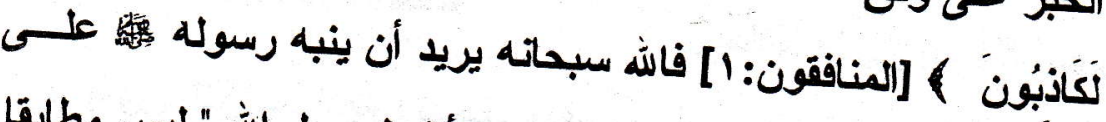
أن ما قاله هؤلاء المنافقون وهو " نشهر أنك لرسول اله " ليس مطابقا لأعتقادهم فحينذ يتنبه الرسول، ويأخذ حذره منهم. 
\&ะ

هذا ما توصلت إليه من أغراض التوكيد "بإن" فى القرآن الكريم وكيــ تلت أولا: لا يمكن هصرما فى هذا البحث المدود، والذى أريد أن أنبه عليه، أته من المعن أن نلمع فى الآية الواحدة أكثر من غـرض، لأن النكات البلاغية لا تتزاصم كما يتول البلاغيون، وكما قال أبو موسى "لا

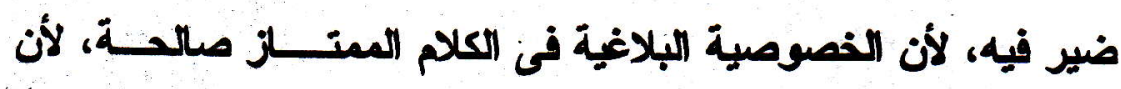
تشير إلى أكثر من معنى، والمهم أن تعرف توجه خصائص الاســـاليب وتدرك منها مالا يفيو عن مقامهال)

( ) (1 خصاتص التراكيب ص\& 